\title{
Efeitos da ingestão de cafeína, café (Coffea arabica) e chá-mate (Ilex paraguariensis) sobre a atividade lipolítica do tecido adiposo e parâmetros metabólicos em ratos submetidos ao exercício físico
}

\author{
Luciane Arias Saldanha
}

Tese apresentada ao Programa de Pós-Graduação em Nutrição em Saúde Pública para obtenção do título de Doutora em Ciências

Área de Concentração: Nutrição em Saúde Pública

Orientadora: $\operatorname{Prof}^{\mathrm{a}} \quad \operatorname{Dr}^{\mathrm{a}}$ Deborah Helena Markowicz Bastos

São Paulo

2012 
É expressamente proibida a comercialização deste documento, tanto na sua forma impressa, quanto eletrônica. Sua reprodução total ou parcial é permitida exclusivamente para fins acadêmicos e científicos, desde que na reprodução figure a identificação do autor, título, instituição e ano da tese. 
“Cada sonho que você deixa para trás, é um pedaço do seu futuro que deixa de existir"

(Steve Jobs) 


\section{DEDICATÓRIA}

"Se eu vi mais longe, foi por estar de pé sobre ombros de gigantes"

(Isaac Newton)

Dedico este trabalho ao meu grande amor, meu marido Carlos Augusto Saldanha, o grande incentivador que me ajudou enxergar a importância de realizar esta pósgraduação e me deu muita força para que eu não desistisse diante das adversidades. 


\section{AGRADECIMENTOS}

$\mathrm{Eu}$ pensei em fazer apenas um agradecimento neste trabalho, mas não seria nada simpático. Meu grande e único agradecimento seria a Deus. Agradeceria por ele me dar saúde e entusiasmo para a execução deste trabalho, mas, fundamentalmente, por colocar no meu caminho seus melhores representantes que habitam a terra, cada um tão fundamental nas diversas etapas pelas quais passei. Tudo o que eu disser será pouco para estas pessoas tão iluminadas e especiais. Sendo assim, meus sinceros agradecimentos:

- aos meus pais, Emidia e Wagner, que são meus primeiros e grandes ídolos da vida, sempre me acolhendo, me apoiando, me acalmando e fazendo assim com que tudo na minha vida pareça tão descomplicado;

- ao meu marido, Carlos Saldanha, um grande homem, dotado de sabedoria, generosidade, bondade sem igual, que jamais deixou que eu desanimasse, fazendo sempre com que eu acreditasse muito em mim mesma;

- aos meus sogros, Maria Helena e Adérito, pessoas muito queridas, que torceram e vibraram verdadeiramente a cada conquista minha durante mais esta jornada;

- à minha irmã, Alessandra Ono, que sempre foi um grande exemplo para mim e sempre tentou ajudar quando precisei; 
- aos meus sobrinhos, Tati e Léozinho, pelo simples fato de existirem, renovando constantemente minhas esperanças e me mostrando sempre que a verdadeira alegria da vida é algo muito simples e possível;

- ao professor José Alfredo Arêas, que, por meio de sua receptividade e grande carisma, abriu as portas da FSP-USP para mim, fazendo com que eu acreditasse que tudo isso um dia seria possível;

- à minha orientadora, professora Deborah Bastos, pela grande oportunidade e por toda a confiança depositada em mim em todos os momentos, fazendo novamente com que fosse possível a realização de mais este sonho;

- à professora Alessandra Medeiros, por ser sempre tão amiga e solidária, sempre disposta a prestar sua preciosa ajuda em todos os momentos de dificuldade e pela grande contribuição com as sugestões para este trabalho;

- à professora Fabiana Evangelista, que me deu as mãos em um dos momentos que eu mais precisava e ainda me concedeu a ajuda tão especial da Talita Higa. Graças a todo empenho, viabilizaram a realização deste trabalho, até sua finalização;

- ao professor Paulo Ramirez e à professora Patrícia Brum, que mais uma vez me receberam de braços abertos na EEFE-USP e disponibilizaram toda sua estrutura física e pessoal do laboratório, tão fundamentais neste processo; 
- ao amigo Luiz Bechara. Para ele me faltam as palavras. Se há alguém que desconhece o egoísmo e transborda em generosidade, posso dizer que tive o privilégio de conhecer. Apesar de todas as adversidades pelas quais passou com seu próprio trabalho, não perdeu seu bom humor e me ajudou quando eu mais precisava, em alguns momentos inadiáveis (graças a ele, consegui adquirir experiência em tempo recorde para realizar um experimento com animais, que até então era um mistério para mim). Muito obrigada também à Vanessa, namorada do Luiz, pela compreensão nos dias mais difíceis;

- ao querido André Vessoni, ex-aluno da graduação, agora Bacharel em Esporte. Com experiência e cabeça de doutor, ele literalmente suou ao meu lado em alguns dias bem difíceis, porém seguiu firme, fazendo com que eu conseguisse cumprir os objetivos propostos. Posso dizer que ele é um verdadeiro guerreiro;

- ao Luciano Lopes, amigo do biotério, uma figura amável e receptiva, que me salvou e também me divertiu em muitos momentos;

- ao Alex Monteiro, amigo do laboratório, uma pessoa adorável e com quem sempre pude contar nos momentos de dificuldade;

- ao Renato Barroso, grande e precioso amigo, posso dizer que é um herói. Sempre disposto e pronto para ajudar. Com toda sua calma, sabedoria e competência me mostrou que seria possível chegar ao final deste trabalho; 
- à minha poliatleta preferida, Bianca Miarka, grande amiga que fiz durante o doutorado e que pretendo conservar por toda a vida, nem que seja apenas para tomarmos juntas um chá ou café com vanilla, enquanto certamente ela me ensinará um pouco mais sobre a vida;

- à Daniela Oliveira, por toda a amizade, carinho e também pela grande ajuda em todos os assuntos que eu desconhecia;

- à querida amiga Cristina Machado, que torceu e se preocupou muito comigo durante estes anos, sempre vibrando positivamente em meu favor;

- à Rosana Manoglio e à Geni Sampaio, duas queridas amigas e responsáveis por laboratórios na FSP-USP. Sempre esclarecendo minhas dúvidas e fazendo com que as mesmas parecessem pertinentes, apenas para não me desanimarem.

- à agência de fomento à pesquisa CAPES, pelo auxílio financeiro (bolsa de estudos) que me foi concedida;

- aos amigos, Bianco, Marcele, Juliane, Paulo, Kátia, Telminha, Stephano, Glorinha, Katt, Vânia e Angela e também a todos os tantos outros que sempre estiveram por perto de alguma forma, muitíssimo obrigada! 


\section{RESUMO}

Saldanha LA. Efeitos da ingestão de cafeína, café (Coffea arabica) e chá-mate (Ilex paraguariensis) sobre a atividade lipolítica do tecido adiposo e parâmetros metabólicos em ratos submetidos ao exercício físico [tese de doutorado em Ciências]. São Paulo: Faculdade de Saúde Pública USP; 2012.

Introdução. $\mathrm{O}$ estoque excessivo de lipídeos no organismo está associado à diversas doenças crônicas não transmissíveis. O exercício físico aumenta a utilização dos lipídeos. A mobilização dos ácidos graxos (AG) é a primeira etapa para que eles sejam utilizados como fonte energética pelo músculo esquelético. Para otimizar esse processo, têm sido estudadas substâncias que poderiam aumentar a lipólise, como a cafeína. O café e o chá-mate contêm cafeína em sua composição. Objetivo. Comparar os efeitos da ingestão de cafeína, café e chá-mate sobre o desempenho físico, parâmetros metabólicos e lipólise em resposta ao exercício físico agudo em esteira rolante, em ratos Wistar. Métodos. O estudo foi divido em etapas 1 (exercício até a exaustão, $n=15)$ e 2 (exercício com duração de 60 minutos, $n=45$ ). A amostra foi composta por cinco grupos: controle (C), controle exercício (CE), cafeína exercício (CFNE), café exercício (CAFE) e chá-mate exercício (CME). Na etapa 1, foram comparados o desempenho, as diferenças na massa corporal e na glicemia (pós versus pré-exercício) e a atividade lipolítica. $\mathrm{Na}$ etapa 2, foram comparadas as diferenças na massa corporal e na glicemia (pós versus pré-exercício), a atividade lipolítica, o lactato sanguíneo e o glicogênio muscular. Os dados foram apresentados segundo a estatística descritiva (média \pm erro padrão). Os dados foram analisados através de modelos gerais lineares e os deltas através da técnica de contrastes 
ortogonais. Para verificar associação entre as variáveis de interesse foi utilizada a correlação linear de Pearson. Resultados. Na etapa 1 não foram observadas diferenças entre os grupos com relação ao desempenho. A massa corporal pósexercício, quando comparada à pré-exercício, diminuiu nos grupos CE (188\%), CFNE (273\%), CAFE (319\%) e CME (204\%), quando comparados ao C. Não houve diferença para a variação de glicemia entre os grupos. Observou-se aumento de $92 \%$ da lipólise no grupo CAFE, quando comparado ao grupo C. Na etapa 2, houve diminuição da massa corporal (pós versus pré-exercício) nos grupos CE e CFNE (263\%), CAFE (230\%) e CME (183\%), quando comparados ao C. A glicemia aumentou nos grupos CFNE (variação pós versus pré-exercício de 343\% e 220\%, quando comparada aos grupos $\mathrm{C}$ e $\mathrm{CE}$, respectivamente) e $\mathrm{CME}$ (179\%, quando comparada ao C). A lipólise estava aumentada nos grupos CFNE e CAFE, quando comparados aos grupos C (150\% e $233 \%$, respectivamente) e CE (51\% e $101 \%$, respectivamente). Não foram observadas diferenças significantes entre os grupos para a concentração sanguínea de lactato e para o conteúdo de glicogênio muscular. Não houve correlação entre as variáveis, em ambas as etapas. Conclusão. Após o exercício até a exaustão, o grupo que ingeriu café apresentou aumento da atividade lipolítica. Após 60 minutos de exercício, o grupo que ingeriu cafeína, assim como o que ingeriu chá-mate, apresentou aumento da glicemia. A cafeína e o café promoveram aumento da lipólise.

Descritores: Cafeína, Café, Chá-mate, Lipólise, Exercício físico 


\begin{abstract}
Saldanha LA. Efeitos da ingestão de cafeína, café (Coffea arabica) e chá-mate (Ilex paraguariensis) sobre a atividade lipolítica do tecido adiposo e parâmetros metabólicos em ratos submetidos ao exercício físico./Effects of the ingestion of caffeine, coffee (Coffea arabica) and roasted maté tea (Ilex paraguariensis) on the adipose tissue lipolytic activity and metabolic parameters on rats submitted to physical exercise [thesis]. São Paulo (BR): Faculdade de Saúde Pública USP; 2012.
\end{abstract}

Introduction. The excess of body fat is associated with the development of chronic non-communicable diseases. Physical exercise enhance lipolysis. The mobilization of fatty acids (FA) is the first stage for the use of lipids as a source of energy by skeletal muscle. In order to increase the use of FA, substances have been used. Objective. This work compared the effects of caffeine, coffee and maté tea on the performance, metabolic parameters and lipolysis in response to acute physical exercise on a treadmill, in Wistar rats. Methods. The study was developed in stage 1 (exercise until exhaustion, $\mathrm{n}=15$ ) and stage 2 (exercise lasting for 60 minutes, $\mathrm{n}=45$ ). The design consisted of groups: control (C), control exercise (CE), caffeine exercise (CFNE), coffee exercise (CAFE) and maté tea exercise (CME). For stage 1, the performance, the differences in the total body mass and glucose (post- versus preexercise), and lipolytic activity were compared. For the stage 2, comparisons were made among the differences in the total body mass and glucose (post- versus preexercise), lipolytic activity, blood lactate level and muscular glycogen content. The data were presented as average \pm standard error. The data were analyzed by means of general linear models and the deltas by the orthogonal contrasts technique. Pearson's 
linear correlation was used to check the association between the variables of interest. Results. In stage 1, no differences were observed between the groups in terms of performance. The post-exercise total body mass, when compared to the pre-exercise, decreased for the CE (188\%), CFNE (273\%), CAFE (319\%) e CME (204\%) groups, when compared to $\mathrm{C}$. There was no difference for glucose (post- versus pre-exercise) between groups. An increase of $92 \%$ in lipolysis was observed in the CAFE group, when compared to $\mathrm{C}$. In stage 2 , there was a decrease in the post-exercise total body mass, when compared with pre-exercise, in the CE and CFNE (263\%), CAFE (230\%) and CME (183\%) groups. An increase in post-exercise glucose, in comparison with the pre-exercise, was observed in groups CFNE (343\% and 220\%, when compared to $\mathrm{C}$ and $\mathrm{CE}$, respectively) and $\mathrm{CME}$ (179\%), when compared to $\mathrm{C}$. Lipolysis increased for the CFNE and CAFE groups when compared to groups C (150\% and 233\%, respectively) and CE (51\% and 101\%, respectively). No significant differences were observed between the groups for the blood lactate and the muscular glycogen levels. It wasn't observed correlation between the different variables, for stage 1 and 2. Conclusion. Following exercise until exhaustion, the group which ingested coffee presented an increase in the lipolytic activity. After exercise lasting 60 minutes, the group which ingested caffeine, as well as that which ingested maté tea, presented increased levels of glucose. The animals which ingested caffeine or coffee presented increased levels of lipolysis.

Keywords: Caffeine, Coffee, Maté tea, Lipolysis, Physical Exercise. 


\section{ÍNDICE}

1 INTRODUÇÃO 22

1.1 SOBREPESO E OBESIDADE 22

1.2 O TECIDO ADIPOSO BRANCO E A ATIVIDADE LIPOLÍTICA 23

1.3 EXERCÍCIO FÍSICO E METABOLISMO ENERGÉTICO 25

$\begin{array}{lll}1.4 & \text { CAFEÍNA } & 28\end{array}$

1.4.1 Estrutura Química e Características 28

$\begin{array}{lll}\text { 1.4.2 } & \text { Metabolismo } & 29\end{array}$

1.4.3 Efeitos Relacionados ao Exercício Físico 32

$\begin{array}{lll}1.5 & \text { CAFÉ } & 36\end{array}$

1.5.1 História e Origem 36

1.5.2 Caracterização e Composição Química 38

1.5.3 Propriedades Biológicas 40

1.5.3.1 Efeitos Relacionados ao Exercício Físico 40

$\begin{array}{lll}1.6 & \text { ERVA-MATE }\end{array}$

1.6.1 História e Origem $\quad 42$

1.6.2 Caracterização e Composição Química 43

1.6.3 Propriedades Biológicas 44

2 OBJETIVOS 48

$\begin{array}{lll}2.1 & \text { OBJETIVO GERAL }\end{array}$

2.2 OBJETIVOS ESPECÍFICOS 48

2.2.1 Etapa $1 \quad 49$

$\begin{array}{lll}2.2 .2 & \text { Etapa } 2 & 49\end{array}$

3 METODOLOGIA $\quad 50$ 
$\begin{array}{lll}3.1 & \text { AMOSTRA } & 50\end{array}$

3.2 PREPARO DAS SOLUÇÕES 51

$3.3 \quad$ PROCEDIMENTOS EXPERIMENTAIS 52

3.3.1 Teste de Esforço Máximo 52

$\begin{array}{lll}\text { 3.3.1.1 Preparo } & 52\end{array}$

3.3.1.2 Avaliação da Tolerância ao Esforço Físico Progressivo em Esteira

Rolante

3.3.2 Etapa 1 - Exercício Físico Agudo em Esteira até a Exaustão 54

$\begin{array}{lll}\text { 3.3.2.1 Preparo } & 54\end{array}$

3.3.2.2 Sessão de Exercício Físico em Esteira até a Exaustão 55

3.3.3 Etapa 2 - Exercício Físico Agudo em Esteira com Duração de Sessenta

$\begin{array}{ll}\text { Minutos } & 56\end{array}$

$\begin{array}{lll}\text { 3.3.3.1 Preparo } & 56\end{array}$

3.3.3.2 Sessão de Exercício Físico em Esteira com Duração de Sessenta

$\begin{array}{lr}\text { Minutos } & 58\end{array}$

3.4 EUTANÁSIA E RETIRADA DOS TECIDOS 59

3.5 AVALIAÇÃO DO DESEMPENHO FÍSICO 60

3.6 DETERMINAÇÃO DA GLICEMIA 60

3.7 DETERMINAÇÃO DA CONCENTRAÇÃO SANGUÍNEA DE

$\begin{array}{ll}\text { LACTATO } & 61\end{array}$

3.8 ATIVIDADE LIPOLÍTICA DO TECIDO ADIPOSO 61

3.8.1 Isolamento dos Adipócitos $\quad 61$

3.8.2 Diâmetro e Número de Células Adiposas 62

3.8.3 Determinação da Taxa da Lipólise 63 
3.9 DETERMINAÇÃO DO CONTEÚDO DE GLICOGÊNIO MUSCULAR 64

3.10 MATERIAL QUÍMICO E VEGETAL 65

3.11 DETERMINAÇÃO DOS PRINCIPAIS FITOQUÍMICOS PRESENTES NO CAFÉ E NO CHÁ-MATE

3.11.1 Quantificação e Identificação de Compostos Fenólicos e Cafeína por Cromatografia Líquida de Ultra Eficiência (CLUE) 66

3.12 ANÁLISE ESTATÍSTICA $\quad 68$

$\begin{array}{lll}3.12 .1 & \text { Etapa } 1 & 68\end{array}$

$\begin{array}{lll}3.12 .2 & \text { Etapa 2 } & 69\end{array}$

4 RESULTADOS

4.1 ETAPA 1 - EXERCÍCIO FÍSICO EM ESTEIRA, ATÉ A EXAUSTÃO 71

4.1.1 Avaliação do Desempenho Físico 71

4.1.2 Avaliação da Massa Corporal Pós versus Pré-Exercício 72

4.1.3 Avaliação da Glicemia Pós versus Pré-Exercício 74

$\begin{array}{lll}\text { 4.1.4 Atividade Lipolítica } & 75\end{array}$

4.2 ETAPA 2 - EXERCÍCIO FÍSICO EM ESTEIRA COM DURAÇÃO DE

$\begin{array}{ll}\text { SESSENTA MINUTOS } & 77\end{array}$

4.2.1 Avaliação da Massa Corporal Pós versus Pré-Exercício $\quad 77$

4.2.2 Avaliação da Glicemia Pós versus Pré-Exercício 79

$\begin{array}{lll}\text { 4.2.3 Atividade Lipolítica } & 81\end{array}$

4.2.4 Avaliação do Conteúdo de Glicogênio Muscular 83

4.2.5 Avaliação da Concentração Sanguínea de Lactato 84

4.3 CONCENTRAÇÃO DE COMPOSTOS FENÓLICOS E DE CAFEÍNA NO

CAFÉ E NO CHÁ-MATE 
$\begin{array}{lll}5 & \text { DISCUSSÃO } & 87\end{array}$

6 CONCLUSÃO 103

7 REFERENCIAS BIBLIOGRAFICAS 104

8 CURRICULO LATTES (AUTORA DA TESE) 122

9 CURRICULO LATTES (ORIENTADORA DA TESE) 123 


\section{LISTA DE TABELAS}

Tabela 1. Massa corporal (g) pré e pós-exercício físico até a exaustão, após administração de placebo, cafeína, café ou chá-mate

Tabela 2. Glicemia $(\mathrm{mg} / \mathrm{dL})$ pré e pós-exercício físico até a exaustão, após administração de placebo, cafeína, café ou chá-mate

Tabela 3. Diâmetro dos adipócitos $(\mu \mathrm{m})$ pós-exercício físico até a exaustão, realizado após administração de placebo, cafeína, café ou chá-mate

Tabela 4. Massa corporal (g) pré e pós-exercício físico com duração de sessenta minutos, após administração de placebo, cafeína, café ou chá-mate

Tabela 5. Glicemia $(\mathrm{mg} / \mathrm{dL})$ pré e pós-exercício físico com duração de sessenta minutos, após administração de placebo, cafeína, café ou chá-mate

Tabela 6. Diâmetro dos adipócitos $(\mu \mathrm{m})$ após sessão de exercício físico com duração de sessenta minutos

Tabela 7. Lactato $(\mathrm{mmol} / \mathrm{L})$ imediatamente após a sessão de exercício físico com duração de sessenta minutos

Tabela 8. Concentração $(\mathrm{mg} / \mathrm{g})$ dos principais fitoquímicos presentes no café solúvel (Coffea arabica)

Tabela 9. Concentração $(\mathrm{mg} / \mathrm{g})$ dos principais fitoquímicos presentes no chá-mate tostado solúvel (Ilex paraguariensis) 


\section{LISTA DE FIGURAS}

Figura 1. Estrutura química da cafeína (1,3,7-trimetilxantina)

Figura 2. Estrutura química da paraxantina (1,7-dimetilxantina)

Figura 3. Estrutura química da teobromina (3,7-dimetilxantina)

Figura 4. Estrutura química da teofilina (1,3-dimetilxantina)

Figura 5. Desempenho físico dos animais submetidos à sessão de exercício em esteira, até a exaustão, após administração de placebo, cafeína, café ou chá-mate 71 Figura 6. Variação da massa corporal (g) (pós versus pré-exercício físico até a exaustão), após administração de placebo, cafeína, café ou chá-mate

Figura 7. Variação da glicemia $(\mathrm{mg} / \mathrm{dL})$ (pós versus pré-exercício físico até a exaustão), após administração de placebo, cafeína, café ou chá-mate

Figura 8. Efeito da administração de cafeína, café e chá-mate sobre a taxa de lipólise (ISO-BS) (nmol/10 $0^{6}$ céls.h $\left.\mathrm{h}^{-1}\right)$ em adipócitos isolados, após exercício até a exaustão 77 Figura 9. Variação da massa corporal (g) (pós versus pré-exercício físico com duração de sessenta minutos), após administração de placebo, cafeína, café ou chámate

Figura 10. Variação da glicemia (mg/dL) (pós versus pré-exercício físico com duração de sessenta minutos), após administração de placebo, cafeína, café ou chámate

Figura 11. Efeito da administração de cafeína, café e chá-mate sobre a taxa de

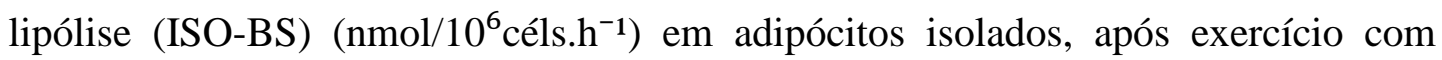
duração de sessenta minutos 
Figura 12. Efeito da administração de cafeína, café e chá-mate sobre o conteúdo de glicogênio muscular (sóleo) (mg/g) após exercício com sessenta minutos de duração 


\section{LISTA DE QUADROS}

Quadro 1. Grupos Experimentais (etapas 1 e 2)

Quadro 2. Esquema sequencial do preparo/duração, previamente à sessão de exercício em esteira até a exaustão

Quadro 3. Esquema temporal da etapa 1 56

Quadro 4. Esquema sequencial do preparo/duração, previamente à sessão de exercício em esteira com duração de sessenta minutos

Quadro 5. Esquema temporal da etapa 2 


\section{SIGLAS UTILIZADAS}

AG - Ácidos Graxos

AGL - Ácidos Graxos Livres

AMP - Adenosina monofosfato

AMPc - Adenosina monofosfato cíclico

ATP - Adenosina trifosfato

C - Grupo Controle

CE - Grupo Controle Exercício

CFNE - Grupo Cafeína Exercício

CAFE - Grupo Café Exercício

CME - Grupo Chá-Mate Exercício

DCNT - Doenças Crônicas Não Transmissíveis

IMC - Índice de Massa Corpórea

LHS - Lipase Hormônio Sensível

OMS - Organização Mundial da Saúde

QR - Quociente Respiratório

SNC - Sistema Nervoso Central

TAB - Tecido Adiposo Branco

TAG - Triacilglicerol

TGIM - Triacilglicerol intramuscular 


\section{INTRODUÇÃO}

\subsection{SOBREPESO E OBESIDADE}

A preocupação com o sobrepeso e com a obesidade vem aumentando muito nos últimos anos. O excesso de massa corporal e a obesidade são reconhecidos como problemas de Saúde Pública, tanto no Brasil, quanto no mundo, e estão entre os cinco principais fatores de risco para as causas de morte globais. São considerados fatores de risco para o desenvolvimento de diversas doenças crônicas não transmissíveis (DCNT), tais como: doenças arteriocoronarianas (DAC), hipertensão arterial sistêmica, diabetes mellitus, hiperlipidemia e diversos tipos de câncer (WHO, 1998). Segundo FINUCANE e colaboradores (2011), entre 1980 e 2008 a obesidade quase dobrou em todo o mundo, afetando cerca de 205 milhões de homens $(9,8 \%)$ e 297 milhões de mulheres $(13,8 \%)$.

A etiologia da obesidade é, sem dúvida, multifatorial. As mudanças ocorridas no comportamento alimentar (aumento da ingestão calórica) associadas ao sedentarismo e à susceptibilidade genética seriam determinantes para o crescimento da obesidade no mundo (WHO, 2011). Desta forma, pode-se dizer que o sobrepeso e a obesidade seriam causados principalmente pela incompatibilidade entre o estilo de vida e a predisposição genética (WHO, 1990).

Sabe-se atualmente que, além da porcentagem total de gordura, a distribuição do tecido adiposo corporal constitui um fator importante. A gordura visceral, 
diferente da gordura periférica, está relacionada ao aumento de distúrbios metabólicos (resistência insulínica e dislipidemias, por exemplo) e ao aumento da ocorrência de problemas cardiovasculares (GODOY-MATOS et al., 2006). Por meio da reeducação alimentar e da prática de exercícios físicos é possível diminuir a ingestão calórica a níveis desejáveis e ocasionar maior gasto calórico ao organismo, auxiliando assim na redução do sobrepeso e da obesidade e consequentemente na prevenção de diversas doenças.

Segundo EGGER (2002), a maior parte das pessoas que precisa emagrecer ainda procura terapias alternativas, como, por exemplo, chás, cápsulas de ervas e massagens. A OMS estima que $80 \%$ da população mundial utilizam plantas medicinais como principal recurso no atendimento básico de saúde (ABIFISA, 2004). Nesse caso, estão incluídas populações que as usam in natura (por opção ou por ser a única alternativa disponível) e os sistemas de medicina que empregam plantas processadas em formulações medicamentosas, como a medicina chinesa (YUNES e CECHINEL, 2001).

\subsection{O TECIDO ADIPOSO BRANCO E A ATIVIDADE LIPOLÍTICA}

O tecido adiposo branco (TAB) é o principal reservatório energético do organismo. As células adiposas, denominadas adipócitos, são as únicas células especializadas em armazenar lipídeos na forma de triacilglicerol (TAG) em seu citoplasma. Os lipídeos armazenados (ésteres de ácidos graxos e glicerol, estocados 
na forma de TAG), representam a fonte corporal mais abundante de energia potencial, sendo a principal reserva energética disponível no homem. Comparada aos outros nutrientes, a quantidade de lipídeos disponível para a produção energética é muito superior, podendo-se dizer quase ilimitada. Os adipócitos possuem todas as enzimas e proteínas reguladoras necessárias para mobilizar os AG (hidrólise do TAG) por meio da lipólise, quando necessário (AHIMA e FILER, 2000).

O metabolismo dos AG (como substrato para o fornecimento de energia), armazenado na forma de TGA no tecido adiposo, é um processo complexo, que envolve diversas etapas no organismo (JEUKENDRUP et al., 1998):

- mobilização de ácidos graxos livres a partir do tecido adiposo, que é processo no qual os TGA são hidrolisados (são quebradas suas ligações éster) em ácidos graxos e glicerol, pela ação da enzima lipase hormônio-sensível (LHS);

- transporte de ácidos graxos livres (ou ácidos graxos não esterificados) ligados à albumina no plasma;

- passagem através do endotélio e do espaço intersticial;

- captação de AG pelo músculo esquelético, por meio de proteínas transportadoras localizadas no sarcolema;

- transporte citoplasmático dos AG para o interior da mitocôndria, por meio do complexo carnitina palmitoil tranferase (CPT)

- oxidação dos AG no interior da mitocôndria, sujeita à regulação da $\beta$ oxidação.

A mobilização é a primeira e determinante etapa para a utilização das gorduras pelos músculos esqueléticos (NEWSHOLME, 1996). Apenas as 
catecolaminas podem estimular a lipólise no homem, em condições fisiológicas (CURI et al., 2003). Como as células do tecido adiposo contêm receptores ( $\beta$ adrenérgicos) específicos para as catecolaminas, a degradação pode ser iniciada via estímulo nervoso simpático, através de descarga adrenérgica (TRUDEAU et al., 1999).

\subsection{EXERCÍCIO FÍSICO E METABOLISMO ENERGÉTICO}

Além de uma alimentação saudável e balanceada, a prática de exercícios físicos regulares constitui uma das melhores formas de prevenir o sobrepeso e a obesidade, além de reduzir o risco de uma série de problemas de saúde. Diversos estudos têm demonstrado que a prática regular de exercícios físicos está associada à redução do risco de doenças cardiovasculares, diabetes mellitus, obesidade, osteoporose e depressão (LAKKA et al., 2003; WAXMAN, 2004; HASKELL et al., 2007). Alguns autores também demonstraram os efeitos agudos da prática de exercícios físicos sobre alguns parâmetros fisiológicos, como: concentração de lipídeos sanguíneos, pressão arterial sistêmica, metabolismo da glicose, dentre outros (THOMPSON et al., 2001; ROWBOTTOM E GREEN, 2000).

Uma das estratégias mais eficazes para evitar e combater o excesso de gordura corporal é fazer com que as pessoas se movimentem mais, pratiquem mais exercícios físicos, auxiliando assim também a prevenção de doenças crônicas não transmissíveis (DCNT). Com o sedentarismo, há perda de massa muscular e de força, 
gradualmente. Quanto menor a quantidade de músculos, menor será a quantidade de energia gasta pelo organismo durante o repouso, sendo assim mais fácil o acúmulo de lipídeos (WILLET, 2002). No caso de indivíduos com sobrepeso ou obesidade, o objetivo primordial da prática de exercícios físicos, além de promover saúde e auxiliar na manutenção ou aumento da massa magra, seria aumentar o gasto calórico proveniente das reservas de gordura corporal, ou seja, aumentar a obtenção de energia a partir dos lipídeos armazenados.

Durante o exercício físico, a demanda por energia, na forma de adenosina trifosfato (ATP), pode aumentar muito de acordo com a intensidade e duração do esforço. Os três sistemas que possibilitam a ressíntese constante do ATP (utilizado para a contração muscular) nos músculos esqueléticos são muito efícientes: fosfocreatina, glicólise e fosforilação oxidativa. Destes sistemas, o da fosforilação oxidativa é o mais complexo e é dependente da utilização do oxigênio. Este sistema tem capacidade praticamente ilimitada e é capaz de fornecer energia para a ressíntese de ATP, principalmente em esforços de longa duração, com intensidades de leve à moderada. Nessas situações, há maior utilização dos AG como substrato energético e as reservas de glicose (glicogênio) são poupadas (WEGENER et al., 1996). O estoque de glicogênio muscular é suficiente para um tempo pouco superior a uma hora de esforço com intensidade moderada, fazendo, desta forma, com que os músculos dependam também da captação da glicose circulante para manter a contração. O glicogênio é fundamental durante o exercício físico, pois a glicose é utilizada simultâneamente aos AG, podendo vir a constituir um fator limitante. A manutenção da glicemia é fundamental, pois quando há redução da mesma, como, por exemplo, em uma maratona, onde pode ser observada uma diminuição da 
glicemia para até aproximadamente $40-50 \mathrm{mg} / \mathrm{dL}$, o indivíduo é levado à exaustão, sendo obrigado a interromper o esforço (YVI et al., 1980). Quanto maior for a disponibilidade de AG, maior será a sua oxidação, diminuindo assim a degradação do glicogênio e, consequentemente, a utilização de glicose como fonte de energia, podendo assim ser utilizada em menores proporções até o final do esforço, sem vir a constituir um fator limitante para o mesmo. O exercício físico promove a liberação intensa dos hormônios lipolíticos, como as catecolaminas (epinefrina e norepinefrina), o glucagon, o hormônio do crescimento e o cortisol (PASTOR et al., 1999). A epinefrina, assim como o glucagon, liga-se aos receptores $\beta$-adrenérgicos que promovem a ativação da enzima LHS, promovendo a lipólise no tecido adiposo (NELSON \& COX, 2002).

Na busca por aumentar ainda mais e também mais precocemente a utilização dos ácidos graxos durante o exercício físico, têm sido estudadas algumas formas de suprir maior quantidade dos mesmos, como a administração de substâncias que aumentem a taxa lipolítica. Uma dessas substâncias é a cafeína. A ingestão de cafeína promove um estímulo constante da lipólise, aumentando a concentração de AG circulantes. Se o indivíduo for sedentário, esses lipídeos circulantes poderiam se depositar nos vasos, precipitando o desenvolvimento da aterosclerose (TIRAPEGUI, 2000). Caso contrário, se o indivíduo for fisicamente ativo, esses lipídeos poderia ser utilizado como substrato energético, podendo proporcionar uma redução nos estoques corporais de TAG, constituindo uma excelente alternativa para o emagrecimento e para prevenção do sobrepeso. 


\subsection{CAFEÍNA}

\subsubsection{Estrutura Química e Características}

As metilxantinas são substâncias orgânicas de origem vegetal, que possuem função amina. A cafeína, a teobromina e a teofilina são as metilxantinas mais abundantes na natureza e fazem parte de um grupo de compostos classificados como alcalóides verdadeiros (alcalóides purínicos), em função de sua marcante atividade biológica, distribuição restrita e presença estrutural de nitrogênio heterocíclico (RATES, 2001). Porém, em razão de sua origem biogenética, provenientes de bases púricas e não de aminoácidos, assim como de seu caráter anfotérico, as metilxantinas são mais apropriadamente classificadas como pseudoalcalóides. Estas substâncias têm diferentes efeitos bioquímicos e estão presentes em diferentes concentrações nas plantas. Dentre as metilxantinas, a mais importante delas é a cafeína $\left(\mathrm{C}_{8} \mathrm{H}_{10} \mathrm{~N}_{4} \mathrm{O}_{2}\right)$ (figura 1). que apresenta uma atividade farmacológica considerável no sistema nervoso central (COSTA, 1994). Devido à diversidade de produtos que contém cafeína, presente em mais de sessenta espécies de plantas, ela é, seguramente, a substância psicoativa mais popular no mundo (GLASS, 1994). Está presente em diversos alimentos e bebidas, como: chocolates, guaraná, cafés, chás, refrigerantes, bebidas energéticas, além de estar presente em diversos medicamentos (MANDEL, 2002). 
A dose letal média (DL50) ${ }^{1}$ da cafeína para ratos é de $261-381 \mathrm{mg} / \mathrm{kg}$ de massa corporal (MERCK INDEX, 1996).

Figura 1. Estrutura química da cafeína (1,3,7-trimetilxantina)

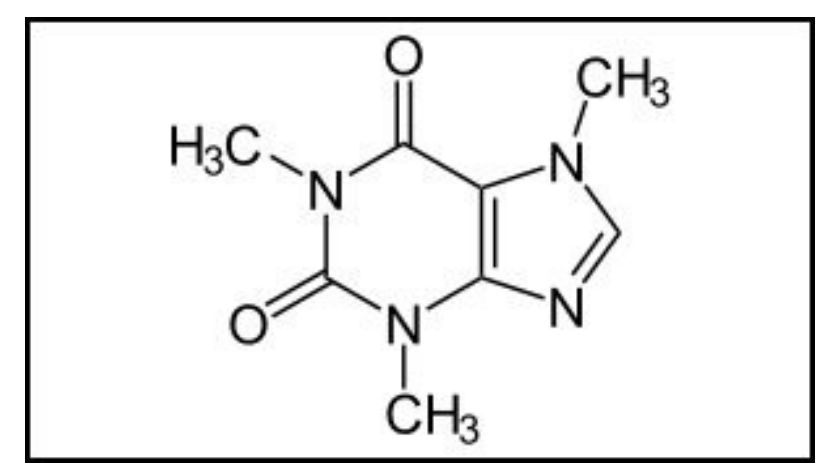

\subsubsection{Metabolismo}

Após ingeridas, as metilxantinas são distribuídas em todo o organismo. A cafeína é uma substância lipossolúvel e, aproximadamente, $100 \%$ de sua ingestão oral é absorvida rapidamente a partir do sistema digestório, tanto em animais, quanto em humanos (SAWYNOK E YAKSH, 1993). Nos 15 - 45 minutos após a ingestão, a cafeína começa a atuar em nível fisiológico, atingindo o máximo efeito no sistema

\footnotetext{
${ }^{1}$ DL 50: (Dose Letal 50\%) ou dose letal média de uma substância expressa o grau de toxicidade aguda de substâncias químicas. Correspondem às doses que provavelmente matam $50 \%$ dos animais de um lote utilizados para experiência. Com base nas DL50 de várias substâncias, são estabelecidas classes toxicológicas de produtos químicos e farmacológicos.
} 
nervoso central (SNC) entre 30- 60 minutos e alcançando concentrações plasmáticas máximas entre 30 - 120 minutos após a ingestão (FERREIRA et al., 2006).

Embora a maior parcela da cafeína sofra metabolização hepática, outros órgãos também podem desempenhar essa função, incluindo o cérebro e os rins. A metabolização inicia-se pela remoção dos grupos metila 1 e 7 . Esta reação é catalizada pelo citocromo P450 1A2, possibilitando assim a formação de três grupos metilxantina. Em humanos, a maior parte desta metabolização, (aproximadamente $84 \%$ ) se processa na forma de paraxantina (figura 2), seguida de teobromina (12\%) (figura 3) e de teofilina (4\%) (figura 4), por meio da mudança na posição do grupo metila 1,3,7. Estes três metabólitos têm se mostrado biologicamente ativos (NABHOLZ, 2007).

Figura 2. Estrutura química da paraxantina (1,7-dimetilxantina)

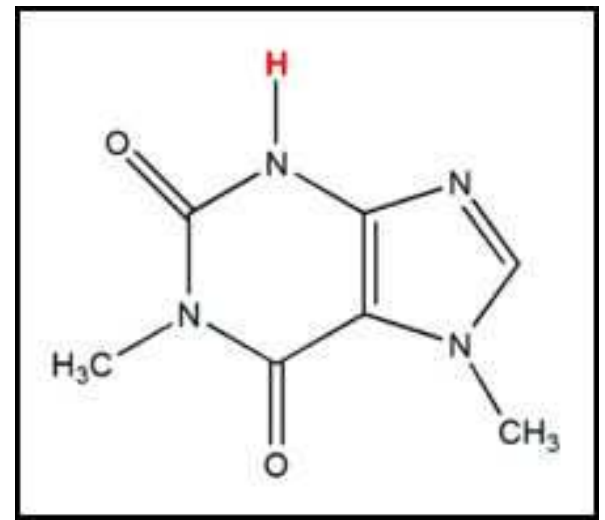


Figura 3. Estrutura química da teobromina (3,7-dimetilxantina)

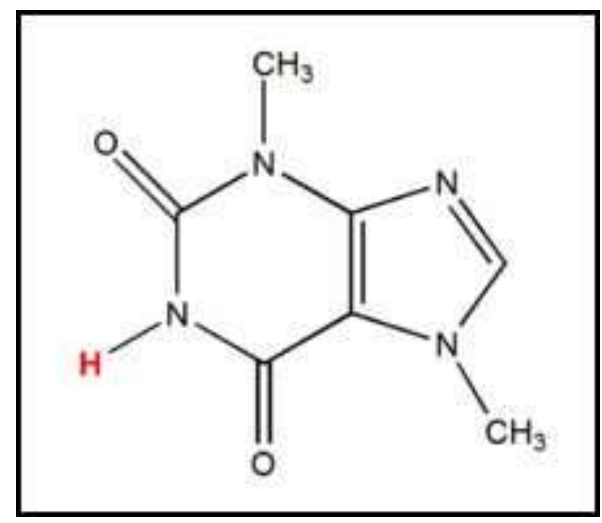

Figura 4. Estrutura química da teofilina (1,3-dimetilxantina)

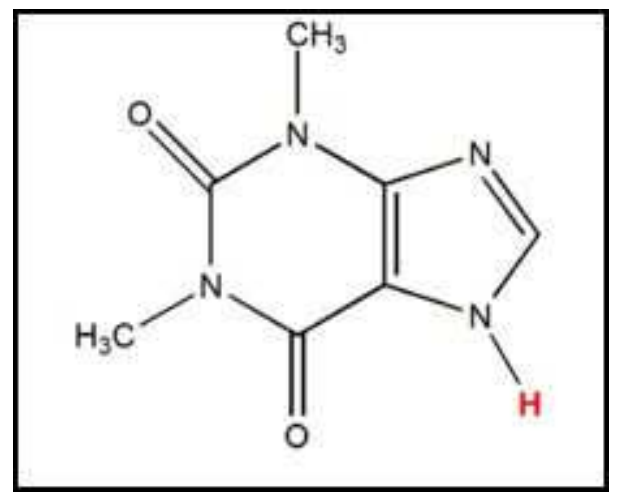

Apenas uma pequena quantidade de cafeína pode ser excretada sem alteração na sua estrutura química $(0,5 \%$ a $3 \%)$ e a sua detecção na urina é relativamente fácil. O tempo necessário para que a concentração plasmática seja reduzida pela metade (meia-vida) varia de três a seis horas, não havendo efeito cumulativo no organismo (BRENELLI, 2003). A cafeína é uma susbtância $\beta$-agonista e que consegue penetrar todas as células do organismo, apresentando efeitos nos sistemas nervoso central, cardiovascular, respiratório, geniturinário, digestório e endócrino (GLASS, 1994). 
Pode induzir à insônia, ao nervosismo, à irritabilidade, à ansiedade, além de náuseas e desconforto gastrintestinal (ALTIMARI et al., 2001).

\subsubsection{Efeitos Relacionados ao Exercício Físico}

O interesse pelos possíveis efeitos ergogênicos da cafeína, principalmente durante exercícios de longa duração, iniciou-se com uma série de três trabalhos realizados por COSTILL e colaboradores, no final da década de setenta/início dos anos oitenta (COSTILL et al., 1978; IVY et al., 1979; ESSING et al., 1980) e, desde então, vêm sendo estudado por diversos pesquisadores (MACINTOSH E WRIGHT, 1995; GRAHAM et al., 1998, SILVEIRA et al., 2004). Os resultados destes estudos apresentam resultados controversos devido à falta de padronização das metodologias utilizadas nos experimentos, como a modalidade, intensidade e duração dos exercícios, dosagens de cafeína e tolerância à substância, por exemplo.

No que diz respeito aos efeitos no metabolismo, a cafeína tem sido associada ao aumento da concentração plasmática de ácidos graxos livres (AGL) no sangue, agindo como uma substância capaz de mobilizar gorduras, poupando glicogênio muscular e retardando a fadiga (DOHERTY E SMITH, 2004; MILLARDSTAFFORD et al., 2007), influenciando também positivamente a contratilidade muscular (MAHAN e ESCOTT-STUMP, 2008). GRAHAM (2001), ao estudar a cafeína e seu impacto no exercício físico, desempenho e metabolismo, observou que esse efeito não sofria influência da tolerância, ou seja, o efeito era observado tanto 
em pessoas que usavam a cafeína esporadicamente, como também nos usuários crônicos.

Acredita-se que a cafeína tenha mecanismos de ação central e periférica. Estes mecanismos poderiam desencadear alterações metabólicas e fisiológicas, resultando assim em um melhor desempenho físico. O efeito direto da cafeína sobre o sistema nervoso central (SNC) afetaria a percepção subjetiva do esforço, bem como a propagação dos sinais neurais entre o cérebro e a junção neuromuscular, e o efeito sobre o músculo esquelético facilitaria o processo de estimulação da contração nos mesmos (ALTIMARI et al., 2005; DEL COSO, 2008; GRAHAM et al., 1998; WILMORE et al., 2001). O mecanismo exato pelo qual a cafeína exerce efeito ergogênico ainda não está totalmente esclarecido. Inicialmente acreditava-se que a menor utilização de glicogênio e uma maior utilização de gordura como substrato energético eram responsáveis pelo aumento na performance (COSTILL et al., 1978), embora a hipótese não tenha sido confirmada depois por GRAHAM e colaboradores (2000), que mostraram efeito ergogênico através da administração de cafeína, porém sem aumento da lipólise.

Dentre as teorias que poderiam explicar esse efeito ergogênico da cafeína, estariam:

- seu efeito direto no sistema nervoso central, podendo afetar a percepção subjetiva do esforço ou otimizando a propagação dos sinais neurais entre o cérebro e a junção neuromuscular;

- seu efeito direto sobre os co-produtos do músculo esquelético, contribuindo para a melhora da contração muscular; 
- sua possível ação lipolítica que, por aumentar a hidrólise dos triacilgliceróis no tecido adiposo ou nos músculos esqueléticos, aumentaria a oxidação dos AG e reduziria a oxidação dos estoques de glicose (SINCLAIR e GEIGER, 2000).

Apesar das teorias que tentam explicar os mecanismos envolvidos, o efeito ergogênico da cafeína ainda é controverso, pois outros mecanismos poderiam estar associados à sua ação durante diferentes protocolos de exercícios físicos (MAUGHAN, 2004). Apesar de os benefícios ergogênicos da cafeína estarem bem estabelecidos em atletas, em sedentários não ocorre o mesmo (WALLMAN et al., 2010).

Tanto a mobilização intracelular de cálcio, quanto os níveis aumentados de AMPc (via inibição da enzima fosfodiesterase), foram apenas observados nos estudos que utilizaram doses suprafisiológicas de cafeína, cujas concentrações sanguíneas seriam tóxicas para o organismo, não podendo assim explicar os efeitos ergogênicos da cafeína. Além da ação na bomba $\mathrm{Na}^{+} / \mathrm{K}^{+}$, o mecanismo que poderia ainda melhor explicar os efeitos ergogênicos da cafeína seria os níveis aumentados AMPc pelo antagonismo dos receptores de adenosina. A adenosina é uma molécula presente em todo o organismo humano e possui dois tipos de receptores $\left(A_{1}\right.$ e $\left.A_{2}\right)$. Ao interagir com os receptores $\mathrm{A}_{1}$, a adenosina inibe a enzima adenilciclase e essa inibição resulta na redução do AMPc. Sendo a cafeína um antagonista dos receptores $\mathrm{A}_{1}$, impede sua interação com a adenosina, aumentando assim o segundo mensageiro, AMPc, provocando assim, diversos efeitos no organismo, dentre eles a liberação de catecolaminas, a ativação do sistema nervoso central e a lipólise (NEHLIG e DEBRY, 1994; TARNOPOLSKY, 1994). 
Além do efeito ergogênico, sobre a performance, a cafeína também tem efeito termogênico, pelo aumento da concentração plasmática de AG. Este último ocorre devido à mobilização das gorduras de seus depósitos e consequente lipólise. A cafeína, principalmente por meio das paraxantinas, exerce efeitos sobre aumento da oxidação dos lipídeos e redução na oxidação de carboidratos, atuando diretamente sobre os tecidos adiposos vasculares e periféricos ou indiretamente também pela estimulação da liberação da adrenalina pelas glândulas supra-renais (HULSTON et al., 2008; KOVACS et al., 1998). A inibição dos receptores da adenosina pela cafeína aumenta a concentração celular do AMPc, que, por sua vez, ativa as lipases, promovendo assim a lipólise. A partir da ativação da lipólise, ocorre a liberação de AGL que serão disponibilizados no plasma. Os níveis elevados de AGL poderiam acelerar a oxidação das gorduras, conservando assim o glicogênio hepático e muscular, favorecendo assim a prática de exercícios de resistência. (DALL AGNOL, 2002; GLAISTER, 2008; GREENBERG, 2006; GRAHAM, 2001; MCARDLE et al., 2001).

Por estes efeitos que a cafeína exerce no organismo e que poderiam auxiliar o desempenho durante os exercícios físicos, até o final de 2003 a cafeína fazia parte da lista de substâncias proibidas (na classe de estimulantes - A) pela Agência Mundial Anti-Doping (WADA). O limite estipulado para ser considerado caso positivo de doping, até aquele momento, era de $12 \mu \mathrm{g}$ de cafeína por $\mathrm{mL}$ de urina (ALTIMERI et al., 2006). Devido às dificuldades de se estabelecer um valor limítrofe para detecção da substância, desde o ano de 2004 a cafeína foi incluída, junto à outras substâncias, em um programa de monitoramento da WADA, deixando assim de ser considerada uma substância proibida até os dias atuais (WADA, 2010). 
Estudos demonstram que doses de $3 \mathrm{mg}$ - $9 \mathrm{mg}$ de cafeína por quilo de massa corporal (3 mg - $9 \mathrm{mg} / \mathrm{kg}$ ) estimulam a lipólise, que doses acima de $9 \mathrm{mg} / \mathrm{kg}$ não produzem efeito adicional na lipólise e doses acima de 10 - $15 \mathrm{mg} / \mathrm{kg}$ elevam os valores séricos de cafeína a um nível tóxico $(200 \mu \mathrm{M})$, podendo levar ao desenvolvimento de arritmias, distúrbios gastrointestinais, alucinações e ansiedade (TIRAPEGUI, 2000; GRAHAM, 2001). A dose letal de cafeína para um ser humano de 70 quilos é de cerca de 10 gramas (142 mg/kg de massa corporal), sendo que uma xícara de café expresso contém cerca de 125 mg de cafeína (JAMES, 1997), infusões de erva-mate e de chá-mate, equivalente a uma xícara de chá e nas concentrações habituais, apresentam, respectivamente, valor médio de $35,5 \mathrm{mg} / 180 \mathrm{~mL}$ (TERRAVISTA, 2002) e 13,0 mg/182 mL (BASTOS et al., 2005).

\subsection{CAFÉ}

\subsubsection{História e Origem}

O café é uma das bebidas mais consumidas no mundo. É o segundo item de maior comercialização no mercado mundial, perdendo apenas para o petróleo, sendo que o Brasil é o maior produtor (MOREIRA et al., 2001) e também o maior exportador global de café (mais de $75 \%$ de sua produção costuma ser da variedade 
arabica) (REUTERS, 2011). Desde sua chegada ao país, em 1727, o café foi o maior gerador de riquezas e o produto mais importante da história nacional.

Não há evidência real sobre a descoberta do café, mas há muitas lendas que relatam sua possível origem. Uma das mais aceitas e divulgadas é a do pastor Kaldi, que viveu na Absínia, hoje Etiópia, há cerca de mil anos. Esta lenda conta que Kaldi, observando suas cabras, notou que elas ficavam alegres e saltitantes e que esta energia extra se evidenciava quando mastigavam os frutos de coloração amareloavermelhada dos arbustos existentes em alguns campos de pastoreio. $\mathrm{O}$ pastor notou que as frutas eram fonte de alegria e motivação e somente com a ajuda delas o rebanho conseguia caminhar por vários quilômetros, por subidas infindáveis. Kaldi comentou sobre o comportamento dos animais a um monge da região, que decidiu experimentar o poder dos frutos. O monge apanhou um pouco das frutas e levou consigo até o monastério. Ele começou a utilizar os frutos na forma de infusão, percebendo que a bebida o ajudava a resistir ao sono enquanto orava ou em suas longas horas de leitura do breviário. Esta descoberta se espalhou rapidamente entre os monastérios, criando uma demanda pela bebida (ABIC, 2011).

A planta de café é originária da Etiópia, centro da África, onde ainda hoje faz parte da vegetação natural. A Arábia foi responsável pela propagação da cultura do café. O nome café não é originário da Kaffa, local de origem da planta, e sim da palavra árabe "qahwa", que significa vinho. Por esse motivo, o café era conhecido como "vinho da Arábia" quando chegou à Europa, no século XIV. Os manuscritos mais antigos mencionando a cultura do café datam de 575 no Yêmen, onde, consumido como fruto in natura, passou a ser cultivado. Somente no século XVI, na 
Pérsia, os primeiros grãos de café foram torrados para se transformar na bebida que hoje conhecemos (ABIC, 2011).

\subsubsection{Caracterização e Composição Química}

O café é uma planta tropical e pertence à família botânica Rubiaceae, com aproximadamente quinhentos gêneros e mais de seis mil espécies (ICO, 2011). Há aproximadamente cem espécies do gênero Coffea. Dessas espécies, a arabica e cannephora (também conhecida como robusta ou conilon) são as mais comercializadas (MONTEIRO e TRUGO, 2005). A espécie arabica possui maior importância econômica e corresponde a 70\% da produção mundial (LIN et al., 2005).

O café industrializado pode ser dividido em: café torrado e moído e café solúvel. De acordo com a Portaria n³77 de 23/04/1999 da Agência Nacional de Vigilância Sanitária (ANVISA), o "Café torrado em grão" é o endosperma beneficiado do fruto maduro de diversas espécies do gênero Coffea (C. arabica, C. liberica Hiern e C. cannephora), submetido a tratamento térmico adequado até atingir o ponto de torra escolhido. De acordo com a portaria, o "Café torrado moído" é o café torrado em grão submetido a processo de moagem adequado (BRASIL, 1999). A Resolução-CNNPA no 12, de 1978, da ANVISA, regulamenta que "Café solúvel ou Extrato de café desidratado" é o produto resultante da desidratação do extrato aquoso de café (Coffea arábica e outras espécies do gênero Coffea) torrado e moído (BRASIL, 1978). 
A composição química do grão verde de café é bastante complexa e durante o processo de torrefação ainda ocorrem diversas reações químicas, através das quais se degradam e/ou formam inúmeros compostos. Estima-se que o grão de café torrado possua mais de 2000 compostos químicos, alguns destes com atividades biológicas conhecidas (SMITH, 1987; ILLY e VIANI, 2005, RANHEIM e HALVORSEN, 2005).

Os cafés arabica e cannephora (conilon) podem ser caracterizados por meio dos teores de alguns de seus principais constituintes (SPEER e KÖLLING-SPEER, 2006; RUBAYIZA e MEURENS, 2005):

- cafeína - pseudoalcalóide que apresenta relativa estabilidade ao processo térmico e contribui para o amargor da bebida (MOREIRA et al., 2000; FRANÇA et al., 2005)

- trigonelina - contribui para o aroma do café pela formação de produtos de degradação durante a torração, principalmente o ácido nicotínico, que também é degradado em grau de torra intenso (TRUGO, 2003; DIAS, 2005);

- ácido 5-cafeoilquínico (5-CQA) - representante majoritário do grupo dos ácidos clorogênicos, principais fenólicos encontrados no café, é intensamente degradado durante a torrefação, originando pigmentos e voláteis aromáticos (KY et al., 2001, MOREIRA et al., 2000; FARAH et al., 2005);

- alcoóis diterpênicos (caveol e cafestol) - estão presentes na fração lipídica insaponificável e são pouco sensíveis ao processo de torra (CAMPANHA et al., 2010). São encontrados apenas no café (SPEER e KÖLLING-SPEER, 2006). 


\subsubsection{Propriedades Biológicas}

A influência do café e de seus compostos na saúde tem sido amplamente descrita (NEHLIG, 1999; HIGDON e FREI, 2006; ALVES et al., 2009) e, além do valor nutricional (pela presença do ácido nicotínico), destacam-se também sua correlação positiva com a atividade antioxidante e seus possíveis efeitos relacionados à redução do risco de desenvolvimento de doenças crônicas não transmissíveis, podendo alguns de seus efeitos serem atribuídos à presença de trigonelina, ácidos clorogênicos e cafeína. Para alguns compostos, como os diterpenos, por exemplo, são atribuídos alguns benefícios, como efeitos hepatoprotetor e anticarcinogênico, mas também alguns efeitos não desejáveis, como a elevação da taxa de colesterol, atribuída ao cafestol (HIGDON e FREI, 2006).

\subsubsection{Efeitos Relacionados ao Exercício Físico}

Além dos efeitos do café e de seus compostos sobre a saúde, por conter cafeína e a mesma estar associada a efeitos ergogênicos e termogênicos durante a prática de exercícios físicos, desde a década de sessenta alguns trabalhos se propuseram a investigar seus efeitos sobre o metabolismo energético (BELLET et al., 1968) e também sobre a performance, durante diferentes tipos de exercícios físicos (COSTILL et al., 1978; ACHESON et al., 1980; GRAHAM et al., 1998). BELLET 
et al. (1968) relataram um aumento nos níveis de AGL plasmáticos após o consumo de café (em humanos) e de cafeína (em cachorros). Os efeitos da ingestão de café descafeinado sobre os AGL plasmáticos foram inferiores, quando comparados aos efeitos do café regular, sendo similares aos da ingestão da bebida controle. Em seu trabalho original, COSTILL et al. (1978), relataram um aumento de aproximadamente $21 \%$ na performance durante exercício físico após o consumo de café contendo cafeína, quando comparado ao café descafeinado. ACHESON et al., 1980, ao estudarem a administração de cafeína ( $8 \mathrm{mg} / \mathrm{kg}$ ) ou café contendo cafeína (4 $\mathrm{mg} / \mathrm{kg}$ ) relataram um aumento na taxa metabólica nas três horas seguintes à ingestão, enquanto GRAHAM et al. (1998) encontraram resultados superiores em sujeitos que ingeriram a cafeína isoladamente do café e observaram que doses de cafeína entre 3 - $6 \mathrm{mg} / \mathrm{kg}$ eram tão efetivas quanto doses de $9 \mathrm{mg} / \mathrm{kg}$.

Embora os efeitos do café sobre o metabolismo energético durante a prática de exercícios físicos venham sendo estudados desde o século passado (década de 70), assim como ocorre nos estudos sobre a cafeína nesta mesma situação, talvez os resultados ainda sejam controversos pela falta de padronização entre os diversos trabalhos. 


\subsection{ERVA-MATE}

\subsubsection{História e Origem}

Recebe o nome de erva-mate o produto formado exclusivamente pelas folhas dessecadas, ligeiramente tostadas e esmigalhadas de Ilex paraguariensis, misturadas ou não com fragmentos de ramos jovens, pecíolos e pedúnculos florais (SALINAS, 2002). Nativa da América do Sul, área de dispersão natural de Ilex paraguariensis, vive aproximadamente vinte e cinco anos e atinge os quinze metros de altura em estado natural. Abrange aproximadamente $540.000 \mathrm{~km}^{2}$, compreendendo territórios do Brasil, Argentina e Paraguai. Só no Brasil estão situados $450.000 \mathrm{Km}^{2}$ do total. Ocorre também em regiões subtropicais e temperadas da América do Sul. No Brasil, sua área de dispersão inclui a região centro-norte do Rio Grande do Sul, quase todo o estado de Santa Catarina, centro-sul e sudoeste do Paraná, sul do Mato Grosso do Sul e manchas em São Paulo, Rio de Janeiro e Minas Gerais. É consumida principalmente como chá (obtido a partir da torrefação da erva mate, sem passar por processo de fermentação), chimarrão (bebida popular dos pampas) ou tererê (popular no Paraguai).

A Ilex paraguariensis pode ser apreciada sob o aspecto químico, bromatológico ou como matéria prima de vários subprodutos. Os primeiros a fazerem uso da erva-mate foram os índios Guarani, que habitavam a região definida pelas bacias dos rios Paraná, Paraguai e Uruguai, na época da chegada dos 
colonizadores espanhóis. Segundo relatos, a erva-mate já era utilizada pelos índios, que conheciam suas virtudes, como a de aumentar a resistência física à fadiga (os índios a usavam como estimulante para vencer o cansaço das longas caminhadas pela floresta, quando estavam em busca de comida e durante a caça e a pesca) e também para reduzir a sede ou a fome. Na medicina popular ela é recomendada para o tratamento de artrite, dores de cabeça, constipação, reumatismos, hemorróidas, obesidade, fadiga, retenção hídrica, hipertensão, digestão lenta e desordens hepáticas (BASTOS \& TORRES 2003).

\subsubsection{Caracterização e Composição Química}

As investigações químicas relativas à erva-mate iniciaram-se em 1836, constatando a presença de diversas substâncias resinosas, matéria corante amarela e ácido tânico, por exemplo. A identificação do principal alcalóide, a cafeína, ocorreu em 1843. Em 1848 foi descoberto o ácido do mate - o ácido café-tânico, já conhecido das sementes do café. Os principais componentes da erva-mate podem ser associados nos seguintes grupos: polifenóis, alcalóides, aminoácidos, vitaminas, componentes voláteis, componentes minerais, saponinas, clorofila, carotenóides, lipídeos, ácidos orgânicos, proteína, celulose, lignina e enzimas. As bebidas à base de erva-mate contêm vários compostos bioativos (metilxantinas, saponinas e os compostos fenólicos). Para HECK e MEJIA (2007), as xantinas encontradas no mate incluem a cafeína, em maior concentração (de $1 \%$ a $2 \%$ da massa do material seco), seguida da teobromina $(0,3 \%$ a $0,9 \%)$. Ao pesquisarem as xantinas em folhas de 
erva-mate, Borille et al. (2005) encontraram concentrações de 1,67\% a 2,22\% para a cafeína. No mesmo ano, POKOLENKO e SCHMALKO (2005), encontraram conteúdo de cafeína que variava de $0,95 \%$ a $1,24 \%$. Na classe das saponinas, responsáveis pelo índice de amargor e pela espuma do produto (devido à presença de propriedades emulsivas), encontram-se as gliconas, os ácidos ursóico e oleanólico (GNOATTO et al., 2005).

Com relação aos compostos fenólicos, os mais abundantes na erva-mate são os ácidos fenólicos (BASTOS et al., 2006; BASTOS et al., 2005 e CARINI et al., 1998). Entre os compostos fenólicos presentes na erva-mate, destacam-se, pela sua elevada concentração, o 5-CQA e seus isômeros, aos quais são atribuídas ações adstringentes e antioxidantes (CARDOZO-JUNIOR et al., 2007).

\subsubsection{Propriedades Biológicas}

GUGLIUCCI (1996), após verificar os efeitos de uma bebida à base de erva mate, concluiu que as substâncias antioxidantes foram absorvidas e atingiram níveis plasmáticos suficientes para inibir a autoxidação da LDL induzida pelo cobre. Resultados diferentes foram encontrados por OLTHOF et al. (2003) ao analisarem o metabolismo do ácido clorogênico, da quercetina3-rutinosídeo e dos fenólicos do chá preto. Nessa pesquisa concluíram que a maioria dos fenólicos consumidos na dieta é extensivamente metabolizada nos seres humanos em compostos com menor potencial antioxidante, principalmente depois de entrarem na circulação. Sabe-se que após a ingestão, os fenólicos são conjugados primeiramente no intestino delgado e, após, no 
fígado. Podem ser detectados no plasma a partir de uma até sete horas após sua ingestão, estando geralmente conjugados com o ácido glucurônico ou como compostos metilados e sulfatados (NARDINE et al. 2002; MANACH et al. 2004; Scalbert et al. 2005). De acordo com OLIVEIRA e BASTOS (2010), os dados sobre as concentrações teciduais de compostos fenólicos são escassos e para os ácidos clorogênicos ainda são inexistentes.

BASTOS et al. (2007) e HECK \& MEJIA (2007) em revisão mostram diversos estudos nos quais podem ser observadas propriedades atribuídas à ervamate. A grande maioria dos trabalhos relacionados foi conduzida com a erva-mate beneficiada para chimarrão, isto é, a erva-mate verde, seca e cancheada. BASTOS et al. (2007) estudaram a atividade antioxidante in vitro de extratos de erva-mate, tanto verde como tostada, e verificaram que extratos de chá-mate tostado tinham um poder antioxidante tão ou mais elevado do que extratos do que a erva-mate verde.

Além dos possíveis efeitos antioxidantes no organismo, bebidas à base de erva-mate poderiam ter outros efeitos benéficos. MARTINET et al. (1999) verificaram, ao comparar o efeito termogênico (por meio do quociente respiratório QR) de algumas preparações para o tratamento do sobrepeso, que apenas o tratamento com Ilex paraguariensis (1,5 g) apresentou uma redução no QR quando comparado ao placebo, indicando uma maior proporção de lipídeos oxidados após a ingestão aguda da erva. Tendo como foco de seu estudo uma bebida composta, dentre outras ervas, por erva-mate, ANDERSEN e FOGH (2001) realizaram um trabalho interessante, onde demonstraram o poder de emagrecimento desta bebida, por meio do aumento da velocidade do esvaziamento gástrico. PANG et al. (2008) observaram uma redução no acúmulo visceral de gordura, sugerindo que a erva-mate 
poderia reduzir o apetite e, consequentemente, prevenir a obesidade. PRZYGODDA et al. (2009) estudaram o efeito da ingestão de uma bebida à base de erva-mate (5 g erva-mate/100 mL de água), ad libitum, em grupos de animais com dietas rica em gordura e também com dieta rica em açúcares. Após o período experimental, com duração de sessenta dias, não observaram efeitos tóxicos e nenhuma anormalidade anatomopatológica após dissecção de tecidos, além de encontrarem como principal efeito, uma diminuição no tecido adipos branco periepididimal nos grupos que ingeriram a bebida. No mesmo ano, ARÇARI et al. (2009) estudaram o efeito da administração de chá-mate solúvel (1,0 e 2,0 g. $\left.\mathrm{kg}^{-1}\right)$ em camundongos obesos, e, após sessenta dias de intervenção, observaram redução significativa no peso corporal, glicemia, resistência à insulina, concentração de colesterol e triacilglicerol dos animais que receberam a bebida. Já SILVA et al. (2011), ao estudarem o efeito da ingestão de bebida à base de erva-mate (tanto com erva-mate não submetida a tratamento industrial quanto àquela processada industrialmente), em concentração semelhante à do chimarrão consumido no Brasil, observaram, após intervenção por 30 dias em ratos Wistar machos, aumento da glicemia no grupo que ingeriu a bebida com a erva não industrializada, assim como diminuição dos depósitos de gordura periepididimal e intra-abdominal no mesmo grupo, embora sem haver diferença na quantidade de massa corporal total, atribuindo em parte esses efeitos à maior presença de glicose e metilxantinas na erva não industrializada.

Há fortes indícios dos benefícios da erva-mate, porém muitos estudos científicos, bem controlados, precisam ser feitos para comprovarem as teorias existentes. Até o momento, nenhum estudo se propôs a investigar os efeitos da Ilex paraguariensis durante o exercício físico. Baseado nos relatos indígenas sobre seus 
possíveis efeitos durante longas caminhadas e sabendo que nesta situação há grande demanda energética, com maior mobilização de substratos para suprir esta necessidade, seria interessante utilizar um protocolo de exercício físico para observar se poderia haver algum efeito do chá-mate sobre a mobilização de gorduras do tecido adiposo, bem como os efeitos sobre a glicemia nesta situação e também se sua ingestão poderia interferir no tempo total de exercício, o que poderia confirmar o aumento da resistência física à fadiga. 


\section{OBJETIVOS}

\subsection{OBJETIVO GERAL}

Avaliar os efeitos da ingestão de cafeína, de café e de chá-mate tostado sobre o desempenho físico, parâmetros metabólicos e taxa de lipólise, em ratos submetidos ao exercício físico agudo em esteira.

\subsection{OBJETIVOS ESPECÍFICOS}

O presente estudo foi dividido em duas etapas: etapa 1 (exercício físico em esteira até a exaustão, após a ingestão de placebo, cafeína, café ou chá-mate tostado) e etapa 2 (exercício físico em esteira com duração de sessenta minutos, após a ingestão de placebo, cafeína, café ou chá-mate tostado). 


\subsubsection{Etapa 1}

Avaliar o efeito das intervenções (exercício físico até a exaustão, após administração de cafeína, de café e de chá-mate), sobre:

- o desempenho físico;

- a massa corporal;

- a glicemia;

- a taxa de lipólise no tecido adiposo.

\subsubsection{Etapa 2}

Avaliar o efeito das intervenções (exercício físico com duração de sessenta minutos, após administração de cafeína, de café e de chá-mate), sobre:

- a massa corporal;

- a glicemia;

- a taxa de lipólise no tecido adiposo;

- a concentração sanguínea de lactato;

- o conteúdo de glicogênio muscular. 


\section{METODOLOGIA}

\subsection{AMOSTRA}

No total, foram estudados sessenta ratos Wistar, machos, provenientes do Biotério Central da Unifesp, com idades entre oito e doze semanas, no início dos experimentos, respectivamente etapas $1(n=15)$ e $2(n=45)$. Os grupos experimentais foram definidos de acordo com o quadro 1. Durante todo o período do estudo, permaneceram em gaiolas, com três ou quatro animais cada, e foram alimentados com dieta laboratorial padrão e água ad libitum. A temperatura ambiente foi mantida entre $22-23^{\circ} \mathrm{C}$ e foi adotado ciclo invertido claro/escuro de 12 horas. Todos os procedimentos foram realizados de acordo com os Princípios Éticos de Experimentação Animal adotados pelo Colégio Brasileiro de Experimentação Animal (COBEA). ${ }^{2}$ O projeto de pesquisa, sob $n^{\circ} 2009$ /52, foi aprovado pelo Comitê de Ética em Pesquisa (CEP) da Escola de Educação Física e Esporte da Universidade de São Paulo - EEFEUSP.

\footnotetext{
2 Colégio Brasileiro de Experimentação Animal (COBEA, www.cobea.org.br)
} 
Quadro 1. Grupos Experimentais (etapas 1 e 2)

\begin{tabular}{|c|c|c|c|c|}
\hline Grupos Experimentais & Intervenção & Exercício Físico & Etapa l (n=) & Etapa 2 (n=) \\
\hline Controle (C) & Agua & Não & 3 & 8 \\
Controle Exercicio (CE) & Água & Sim & 3 & 9 \\
Cafeina Exercicio (CFNE) & Cafeina & Sim & 3 & 9 \\
Café Exercicio (CAFE) & Café & Sim & 3 & 9 \\
Chá-Mate Exercicio (CME) & Chá-mate & Sim & 3 & 10 \\
\hline
\end{tabular}

Inicialmente, os animais passaram por um período de adaptação (com duração de duas semanas) ao ambiente no qual a pesquisa foi conduzida (Biotério da EEFEUSP).

\subsection{PREPARO DAS SOLUÇÕES}

- Solução de cafeína - Foi utilizada cafeína, dissolvida em água filtrada, de forma que o volume final a ser administrado $(1 \mathrm{~mL})$ contivesse $7 \mathrm{mg}$ de cafeína / $\mathrm{kg}$ de massa corporal do animal;

- Solução de café granulado solúvel: Foi utilizado café granulado solúvel, dissolvido em água filtrada, de forma que o volume final a ser administrado $(1 \mathrm{~mL})$ contivesse $250 \mathrm{mg}$ de café / $\mathrm{kg}$ de massa corporal do animal, o equivalente a aproximadamente 7 mg de cafeína / kg de massa corporal;

- Solução de chá-mate solúvel: Foi utilizado chá-mate solúvel, dissolvido em água filtrada, de forma que o volume final a ser administrado $(1 \mathrm{~mL})$ contivesse $500 \mathrm{mg}$ 
de chá-mate / $\mathrm{kg}$ de massa corporal do animal, o equivalente a aproximadamente 7 mg de cafeína / kg de massa corporal;

\subsection{PROCEDIMENTOS EXPERIMENTAIS}

\subsubsection{Teste de Esforço Máximo}

\subsubsection{Preparo}

Previamente ao teste de esforço máximo, todos os animais foram submetidos a um período de adaptação ao exercício, em esteira rolante, que consistiu na prática da caminhada/corrida durante 10 minutos, utilizando-se velocidades variadas, por cinco dias alternados.

No dia do teste, os animais $(n=60)$ foram pesados (para controle) e a ração foi retirada pelo período de três horas. Após as três horas de jejum, os animais tiveram a ração reintroduzida e disponibilizada pelo período de uma hora, a fim de garantir que todos os animais estivessem alimentados no início do experimento (pôde-se observar os animais se alimentando durante este período). Após o período de uma hora com a ração disponibilizada, a mesma foi retirada novamente. Em nenhum momento, exceto durante o teste máximo, a água foi retirada, evitando-se assim que o animal 
pudesse estar desidratado no início do teste. Os animais então aguardaram quarenta e cinco minutos após a retirada da ração e, após este período, tiveram a massa corporal aferida. Imediatamente após este procedimento, o teste em esteira foi iniciado.

\subsubsection{Avaliação da Tolerância ao Esforço Físico Progressivo em Esteira Rolante}

Após o período de adaptação, os animais foram submetidos a um teste progressivo de esforço máximo em esteira, até a exaustão, para determinação da velocidade máxima individual. A partir deste teste, foi determinada a velocidade experimental de $70 \%$ da velocidade máxima individual, que foi utilizada durante as subsequentes sessões de exercício físico agudo (até a exaustão e com sessenta minutos de duração).

O protocolo utilizado para o teste teve velocidade inicial de $6 \mathrm{~m} / \mathrm{min}$, sendo a mesma intensificada a cada 3 minutos, com um incremento da velocidade de $3 \mathrm{~m} / \mathrm{min}$, até chegar o momento no qual o animal não conseguisse manter o padrão de corrida (adaptado de SILVA, BRUM, NEGRÃO \& KRIEGER, 1997). Durante o teste, os animais do grupo controle $(\mathrm{C})$ foram expostos ao mesmo ambiente que os demais (foram mantidos em caixas, situadas sobre as baias das esteiras, para que eles fossem submetidos à situação semelhante, incluindo barulho e tremor), pelo mesmo tempo aproximado que os outros animais permaneceram na esteira. 
Após o teste máximo, os ratos foram distribuídos nos cinco grupos experimentais (C, CE, CFNE, CAFE e CME) de acordo com o desempenho obtido no teste de esforço máximo (velocidades médias no teste máximo: $33 \mathrm{~m} / \mathrm{min}$, etapa 1 e $28 \mathrm{~m} / \mathrm{min}$, etapa 2), com o objetivo de manter similaridade entre os grupos experimentais, ou seja, fazer com que todos grupos contivessem animais com desempenhos em todos os níveis (capacidade média de desempenho similar entre os grupos).

\subsubsection{Etapa 1 - Exercício Físico Agudo em Esteira até a Exaustão}

\subsubsection{Preparo}

A sessão de exercício agudo em esteira, até a exaustão (etapa 1), foi realizada pelos animais $(\mathrm{n}=15)$, após um período de pelo menos setenta e duas horas após o término do teste de esforço máximo. No dia da sessão, os animais foram pesados (para controle) e a ração foi retirada pelo período de três horas. Após as três horas, os animais tiveram a ração reintroduzida e disponibilizada pelo período de uma hora, a fim de garantir que todos os animais estivessem alimentados no início do experimento (pôde-se observar os animais se alimentando durante este período). Após o período de uma hora com a ração disponibilizada, a mesma foi retirada novamente e os animais foram submetidos à gavagem (realizada com o auxílio de 
uma cânula orogástrica) com a administração de $1 \mathrm{~mL}$ de líquido, conforme o grupo experimental [água filtrada (grupos C e CE), cafeína (grupo CFNE), café (grupo CAFE) e chá-mate (grupo CME)]. Em nenhum momento, exceto durante a sessão de exercício, a água foi retirada, evitando assim que o animal pudesse estar desidratado no início da sessão de exercício. Quarenta e cinco minutos após a gavagem, os animais tiveram a massa corporal medida e uma amostra de sangue foi coletada para aferição da glicemia. Imediatamente após estes procedimentos, a sessão de exercício até a exaustão teve início (quadro 2).

Quadro 2. Esquema sequencial do preparo/duração, previamente à sessão de exercício em esteira até a exaustão

\begin{tabular}{|c|c|c|c|}
\hline Retirada da ração & $\begin{array}{c}\text { Reintrodução da } \\
\text { ração }\end{array}$ & $\begin{array}{c}\text { Retirada da ração } \\
\text { e gavagem }\end{array}$ & $\begin{array}{c}\text { Aferição da massa } \\
\text { corporal dos } \\
\text { animais/ Coleta da } \\
\text { amostra de sangue/ } \\
\text { Início da sessão de } \\
\text { exercício }\end{array}$ \\
\hline 3 horas & 1 hora & 45 minutos & $\ldots$ \\
\hline
\end{tabular}

\subsubsection{Sessão de Exercício Físico em Esteira até a Exaustão}

Durante a sessão de exercício, os animais do grupo controle $(\mathrm{C}), \mathrm{n}=3$, foram expostos ao mesmo ambiente que os demais (permaneceram mantidos em caixas, situadas sobre as baias das esteiras, para que eles fossem submetidos à situação semelhante, incluindo barulho e tremor, pelo mesmo tempo aproximado que os outros animais realizaram o exercício). Os demais animais, grupos CE ( $\mathrm{n}=3$ ), CFNE 
$(n=3)$, CAFE $(n=3)$, CME $(n=3)$, realizaram o exercício em esteira, até a exaustão, sendo que os dez minutos iniciais foram realizados com velocidade progressiva, até atingirem $70 \%$ da velocidade máxima individual (determinadas por meio do teste máximo), permanecendo nessa velocidade constante até que não conseguissem manter o padrão de caminhada/corrida. Todas as medidas, coletas e procedimentos pré e pós-exercício realizados foram feitos também para o grupo (C), em tempos semelhantes à média dos demais grupos, porém o exercício físico não foi realizado.. O esquema temporal completo da etapa 1 está descrito no quadro 3.

Quadro 3. Esquema temporal da etapa 1

\begin{tabular}{|c|c|c|c|c|c|c|}
\hline $\begin{array}{c}\text { Adaptação } \\
\text { ao biotério }\end{array}$ & $\begin{array}{c}\text { Adaptação } \\
\text { à esteira }\end{array}$ & $\begin{array}{c}\text { Teste de } \\
\text { esforço }\end{array}$ & Descanso & $\begin{array}{c}\text { Sessão de } \\
\text { exercicio até } \\
\text { a exaustão* }\end{array}$ & Eutanásia & $\begin{array}{c}\text { Coleta e } \\
\text { análise de } \\
\text { tecidos }\end{array}$ \\
\hline dias & $\begin{array}{c}10 \text { dias } \\
\text { (dias } \\
\text { altemados) }\end{array}$ & 1 dia & $\geq 72$ horas & 1 dia & $\begin{array}{c}\text { Apóso } \\
\text { término do } \\
\text { exercicio }\end{array}$ & $\ldots$ \\
\hline
\end{tabular}

* Imediatamente após a sessão de exercício, antes da eutanásia, os animais tiveram amostras de sangue coletadas e massa corporal aferida

\subsubsection{Etapa 2 - Exercício Físico Agudo em Esteira com Duração de Sessenta Minutos}

\subsubsection{Preparo}


A sessão de exercício agudo em esteira, com duração de sessenta minutos (etapa 2), foi realizada pelos animais $(n=45)$, após um período de pelo menos setenta e duas horas após o término do teste de esforço máximo. No dia da sessão, os animais foram pesados (para controle) e a ração foi retirada pelo período de três horas. Após as três horas, os animais tiveram a ração reintroduzida e disponibilizada pelo período de uma hora, a fim de garantir que todos os animais estivessem alimentados no início do experimento (pôde-se observar os animais se alimentando durante este período). Após o período de uma hora com a ração disponibilizada, a mesma foi retirada novamente e os animais foram submetidos à gavagem (realizada com o auxílio de uma cânula orogástrica) com a administração de $1 \mathrm{~mL}$ de líquido, conforme o grupo experimental [água filtrada (grupos C e CE), solução de cafeína (grupo CFNE), café (grupo CAFE) e chá-mate (grupo CME)]. Em nenhum momento, exceto durante a sessão de exercício, a água foi retirada, evitando assim que o animal pudesse estar desidratado no início da sessão de exercício. Quarenta e cinco minutos após a gavagem, os animais tiveram a massa corporal medida e uma amostra de sangue foi coletada para aferição da glicemia. Imediatamente após, a sessão de exercício com duração de sessenta minutos teve início (quadro 4).

Quadro 4. Esquema sequencial do preparo/duração, previamente à sessão de exercício em esteira com duração de sessenta minutos

\begin{tabular}{|c|c|c|c|}
\hline Retirada da ração & $\begin{array}{c}\text { Reintrodução da } \\
\text { ração }\end{array}$ & $\begin{array}{c}\text { Retirada da ração } \\
\text { e gavagem }\end{array}$ & $\begin{array}{c}\text { Aferição da massa } \\
\text { corporal dos } \\
\text { animais/ Coleta da } \\
\text { amostra de sangue/ } \\
\text { Início da sessão de } \\
\text { exercício }\end{array}$ \\
\hline 3 horas & 1 hora & 45 minutos & $\ldots$ \\
\hline
\end{tabular}




\subsubsection{Sessão de Exercício Físico em Esteira com Duração de Sessenta Minutos}

Durante a sessão de exercício, os animais do grupo controle $(C), n=8$, foram expostos ao mesmo ambiente que os demais (foram mantidos em caixas, situadas sobre as baias das esteiras, para que eles fossem submetidos à situação semelhante, incluindo barulho e tremor, pelo mesmo tempo aproximado que os outros animais realizaram o exercício. Os demais animais, grupos CE (n=9), CFNE (n=9), CAFE $(\mathrm{n}=9), \operatorname{CME}(\mathrm{n}=10)$, realizaram o exercício em esteira, com duração de sessenta minutos, sendo que os dez minutos iniciais foram realizados com velocidade progressiva, até atingirem $70 \%$ da velocidade máxima individual (determinadas por meio do teste máximo), permanecendo nessa velocidade constante até completarem sessenta minutos de exercício. Todas as medidas, coletas e procedimentos pré e pósexercício realizados foram feitos também para o grupo (C), em tempos semelhantes à média dos demais grupos, porém o exercício físico não foi realizado. O esquema temporal completo da etapa 2 está descrito no quadro 5. 
Quadro 5. Esquema temporal da etapa 2

\begin{tabular}{|c|c|c|c|c|c|c|}
\hline $\begin{array}{c}\text { Adaptação } \\
\text { ao biotenio }\end{array}$ & $\begin{array}{c}\text { Adaptação } \\
\text { a esteira }\end{array}$ & $\begin{array}{c}\text { Teste de } \\
\text { esforço }\end{array}$ & Descanso & $\begin{array}{c}\text { Sessão de } \\
\text { exercicio } \\
\text { com duração } \\
\text { de } 60 \\
\text { minutos* }\end{array}$ & Eutanásia & $\begin{array}{c}\text { Coleta e } \\
\text { análise de } \\
\text { tecidos }\end{array}$ \\
\hline 7 dias & $\begin{array}{c}10 \text { dias } \\
\text { (dias } \\
\text { altemados) }\end{array}$ & 1 dia & 272 horas & 1 dia & $\begin{array}{c}\text { Após o } \\
\text { témino do } \\
\text { exercicio }\end{array}$ & $\ldots$. \\
\hline
\end{tabular}

* Imediatamente após a sessão de exercício, antes da eutanásia, os animais tiveram amostras de sangue coletadas e massa corporal aferida

\subsection{EUTANÁSIA E RETIRADA DOS TECIDOS}

Imediatamente após a sessão de exercícios, tanto da etapa 1 (exercício até a exaustão), quanto da etapa 2 (exercício com duração de 60 minutos), os animais tiveram a massa corporal aferida e foram coletadas amostras de sangue caudal. Logo após, foram sacrificados por decapitação. Após incisão abdominal, foi retirado o tecido adiposo periepididimal e, em seguida, foi aferida a sua massa. O tecido adiposo foi utilizado imediatamente após, para que fosse possível realizar o isolamento dos adipócitos. Simultâneamente à retirada do tecido adiposo, o músculo sóleo da pata direita também foi cuidadosamente retirado e dissecado. A massa de ambos os tecidos foi aferida em balança analítica, com precisão de $\pm 0,0001$ g. Após realizadas as medidas, o tecido muscular foi armazenado em microtubo e congelado em nitrogênio líquido, sendo depois transferido para freezer $-80{ }^{\circ} \mathrm{C}$, onde permaneceram até o momento da dosagem do conteúdo de glicogênio. 


\subsection{AVALIAÇÃO DO DESEMPENHO FÍSICO}

Foi empregado o termo "desempenho físico" para designar a capacidade de realização de exercício físico em esteira, com velocidade constante de $70 \%$ da velocidade máxima (obtida em teste de esforço máximo) e realizado até a exaustão. Para essa determinação, foi medido o tempo total de realização do exercício. Para aferição do tempo, foi utilizado o cronômetro digital (Stopwatch PC396 ${ }^{\circledR}$ )

\subsection{DETERMINAÇÃO DA GLICEMIA}

Foram utilizadas lâminas descartáveis para a realização de pequena incisão na ponta distal da cauda de cada animal, sem a utilização de anestésico, para a coleta da amostra de sangue. Para cada animal, foram coletadas duas amostras de sangue (pré e pós-exercício). Para a verificação da glicemia, utilizou-se o sistema Accutrend® Plus (Roche). O aparelho de medição Accutrend ${ }^{\circledR}$ Plus mede a intensidade da cor produzida na camada de reação da tira de teste (Accutrend® Glucose- Roche), por meio de fotometria de reflectância, e calcula a concentração de glicose na amostra por meio de um algoritmo específico de lote. O resultado foi obtido em $\mathrm{mg} / \mathrm{dL}$. 


\subsection{DETERMINAÇÃO DA CONCENTRAÇÃO SANGUÍNEA DE LACTATO}

Foi coletada uma amostra de sangue caudal para cada animal (pós-exercício). Para a verificação do lactato sanguíneo, utilizou-se o sistema Accutrend® Plus (Roche). O aparelho de medição Accutrend® Plus mede a intensidade da cor produzida na camada de reação da tira de teste (Accutrend® BM- Lactate- Roche), por meio de fotometria de reflectância, e calcula a concentração de lactato na amostra por meio de um algoritmo específico de lote. O resultado foi obtido em $\mathrm{mmol} / \mathrm{L}$.

\subsection{ATIVIDADE LIPOLÍTICA DO TECIDO ADIPOSO}

\subsubsection{Isolamento dos Adipócitos}

Os adipócitos foram isolados do tecido adiposo periepididimal mediante a técnica de digestão de tecido pela colagenase, descrita por RODBELL (1964), com algumas modificações para adaptar o método às condições laboratoriais. Imediatamente após o sacrifício do animal, o depósito adiposo periepididimal foi retirado, picado com tesoura em finos fragmentos e incubado em 4,0 mL de tampão digestivo [DMEM, HEPES 25 mM, BSA $4 \%$, colagenase tipo II (Sigma-Aldrich® 
Chemical Co, St. Louis, MO, Estados Unidos)] 1,25 mg/mL, pH 7,45] por cerca de 30 min a $37{ }^{\circ} \mathrm{C}$, em banho-maria com agitação orbital (150 rpm). Em seguida, a amostra foi filtrada em peneira plástica com malha fina (que retém restos teciduais e vasos não digeridos) e "lavada" por três vezes com $25 \mathrm{~mL}$ de tampão EHB (sais de EARLE, HEPES 25 mM, BSA $1 \%$, piruvato de sódio $1 \mathrm{mM}$, sem glicose, pH 7,45), mantido à $37^{\circ} \mathrm{C}$. Após a segunda lavagem, a suspensão celular, em $25 \mathrm{~mL}$ de tampão $\mathrm{EHB}$, foi deixada $30 \mathrm{~min}$ em repouso em estufa a $37{ }^{\circ} \mathrm{C}$, com a finalidade de atenuar os efeitos da insulina e de outros hormônios endógenos. Para a determinação do lipócrito (porcentagem de adipócitos contidos na suspensão celular total), $40 \mu \mathrm{L}$ da suspensão celular em tampão EHB foram colocados em capilar de vidro e submetidos à centrifugação $(2000 \mathrm{rpm}$, por $1 \mathrm{~min})$. O volume total da suspensão corresponde a $100 \%$, e o volume de adipócitos, obtido após a centrifugação, fornece o lipócrito da amostra.

\subsubsection{Diâmetro e Número de Células Adiposas}

Para a análise morfométrica, alíquotas de suspensão celular foram avaliadas em microscópio óptico com o programa Leica Quantimet 500®. Em cada preparação, foram medidas cem células. A partir do diâmetro celular médio e admitindo-se que o adipócito isolado é esférico, o volume e o número de células foram calculados de acordo com as seguintes fórmulas: 
(a) $\mathrm{V}=\left[(\pi / 6) \times \mathrm{D}^{3}\right] / 1000, \quad$ (b) $\mathrm{N}=\left(\right.$ lipócrito $\left.\times 10^{7}\right) / \mathrm{V}$

Onde:

D é o diâmetro médio de 100 adipócitos $(\mu \mathrm{m})$, N é o número de células e V é o volume médio (DI GIROLAMO; MENDLINGER; FERTIG, 1971). A divisão por 1000 visa expressar o volume em picolitros (pL).

\subsubsection{Determinação da Taxa da Lipólise}

A liberação de glicerol para o meio de incubação foi utilizada como índice lipolítico. As taxas de lipólise basal e estimulada pelo agonista $\beta$-adrenérgico isoproterenol (Sigma-Aldrich®) foram mensuradas em adipócitos isolados do tecido adiposo periepididimal conforme o seguinte protocolo: $40 \mu \mathrm{L}$ de suspensão celular (em tampão EHB) foram transferidos para microtubos $(1,5 \mathrm{~mL})$ e incubados durante 5 min a $37{ }^{\circ} \mathrm{C}$ em presença de $20 \mu \mathrm{L}$ de adenosina deaminase (ADA, SigmaAldrich®, 0,2 U/mL em tampão EHB, pH 7,45), para permitir a degradação da adenosina, um metabólito com ação anti-lipolítica, liberada no meio pelos adipócitos (HONNOR; DHILLON; LONDOS, 1985). Após este período, as células foram incubadas por $60 \min$ a $37{ }^{\circ} \mathrm{C}$ com ou sem $10 \mu \mathrm{L}$ de isoproterenol $\left(10^{-5} \mathrm{M}\right)$ totalizando um volume de $200 \mu \mathrm{L}$. Ao final da incubação, a mistura de reação foi bloqueada por meio da transferência dos tubos para o gelo, seguido por centrifugação 
a $12000 \mathrm{rpm}$, por $10 \mathrm{~min}$ a $4{ }^{\circ} \mathrm{C}$, para separar as células do meio de reação. Após a centrifugação, alíquotas de aproximadamente $120 \mu \mathrm{L}$ do meio de incubação foram retiradas e armazenadas em freezer a $-20{ }^{\circ} \mathrm{C}$ para posterior mensuração do glicerol nele contido. A quantidade de glicerol liberada pelos adipócitos para o meio de incubação foi determinada pelo método enzimático-colorimétrico (SigmaAldrich $\left.{ }^{\circledR}\right)$. Os resultados foram expressos em nmol. $10^{6}$ cels. $\mathrm{h}^{-1}$.

\subsection{DETERMINAÇÃO DO CONTEÚDO DE GLICOGÊNIO MUSCULAR}

O conteúdo de glicogênio muscular foi determinado pelo método de antrona, através do protocolo adaptado de BALMAIN et al. (1955). Cerca de $50 \mathrm{mg}$ do músculo sóleo foi digerido em solução a 30\% de hidróxido de potássio $(\mathrm{KOH})$, em banho fervente $\left(100{ }^{\circ} \mathrm{C}\right)$, durante 1 hora. Após a completa digestão do tecido, o glicogênio foi precipitado através da adição de etanol e centrifugação a $3000 \mathrm{~g}\left(4{ }^{\circ} \mathrm{C}\right.$, durante 30 minutos). Em seguida, o glicogênio foi ressuspendido através da adição de solução a $5 \%$ de ácido tricloroacético (TCA) e centrifugação a 3000 g $\left(4{ }^{\circ} \mathrm{C}\right.$, durante 30 minutos). O sobrenadante foi recolhido para quantificação.

Para a quantificação do conteúdo de glicogênio muscular utilizou-se o método de análise colorimétrica, espectrofotometria, através de antrona em solução de ácido sulfúrico concentrado. A antrona reage com a glicose produzida pela quebra do glicogênio, promovendo uma coloração esverdeada. Foi utilizada uma curva padrão com as concentrações de 5, 10, 20, 40 e $80 \mu \mathrm{g}$ de glicose/mL de água deionizada. As 
amostras foram preparadas em tubos na proporção (2:1) $600 \mu \mathrm{L}$ de antrona e $300 \mu \mathrm{L}$ de amostra. Os tubos, contendo as amostras e a solução de antrona, foram levados ao banho fervente por 15 min e, em seguida, alíquotas de $200 \mu \mathrm{L}$ foram pipetadas (triplicata) em placa de 96 poços. A leitura foi realizada em espectrofotômetro utilizando um comprimento de onda de $620 \mathrm{~nm}$. O conteúdo de glicogênio foi determinado a partir da seguinte fórmula:

Glicogênio $(\mathrm{mg} / \mathrm{g}$ de tecido $)=\mathrm{A}(\mathrm{mg} / \mathrm{L}) \times \mathrm{V}(\mathrm{L}) / \mathrm{M}(\mathrm{g})$, sendo:

$A=$ concentração da amostra obtida através da equação da reta gerada da curva padrão de glicose.

V= volume de TCA na ressuspensão do glicogênio

$\mathrm{M}=$ massa do tecido utilizado

\subsection{MATERIAL QUÍMICO E VEGETAL}

A cafeína utilizada para preparo da solução foi a cafeína anidra pura, 1,3,7trimetilxantina (Caffeine, Sigma-Aldrich ${ }^{\circledR}$ Chemical Co, St. Louis, MO, Estados Unidos). Os produtos Matte Leão Solúvel® (chá-mate solúvel) e Nescafé Tradição® (café solúvel granulado), utilizados para o preparo das infusões, foram comprados em Supermercado da rede Pão de Açúcar®. Para cada um dos produtos utilizados, todos os frascos utilizados pertenciam ao mesmo lote. 


\subsection{DETERMINAÇÃO DOS PRINCIPAIS FITOQUÍMICOS PRESENTES NO CAFÉ E NO CHÁ-MATE}

\subsubsection{Quantificação e Identificação de Compostos Fenólicos e Cafeína por Cromatografia Líquida de Ultra Eficiência (CLUE)}

As análises do perfil de compostos fenólicos e cafeína foram realizadas em cromatógrafo líquido Agilent modelo 1200 SL, equipado com detector de arranjo de diodos $(\mathrm{DAD})$ e espectrômetro de massas com fonte de íons eletrospray à pressão atmosférica (API-ESI), modelo Agilent 6150, utilizando coluna Agilent Zorbax SB$\mathrm{C} 18(50 \times 2,1 \mathrm{~mm}, 1.8 \mu \mathrm{m})$.

O extrato de chá-mate tostado foi preparado em triplicata, com diluição 100 mg do chá solúvel em $100 \mathrm{ml}$ de água deionizada, em balão volumétrico. O extrato de café também foi preparado em triplicata, com diluição 100 mg do café solúvel em $100 \mathrm{~mL}$ de água deionizada, em balão volumétrico. Alíquotas de $1 \mathrm{ml}$ foram filtradas com filtro para seringa $0,22 \mu \mathrm{m}$ (Millipore) e $5 \mu \mathrm{L}$ injetados no cromatógrafo.

A fase móvel foi constituída de acido fórmico (Merck) 0,1 \% (v/v) em água deionizada (A) e metanol grau HPLC (Gold, CER Brasil) (B). Os solventes foram filtrados com membrana $0,45 \mu \mathrm{m}$ nylon (Millipore) e degazeificados em ultrassom antes de serem acoplados ao sistema cromatográfico. Antes do início da análise, o sistema foi equilibrado com uma mistura de 85:15 dos eluentes A e B, respectivamente. A programação do gradiente foi: $15 \%$ de B até 1,8 min, $30 \%$ B até 5 min, $35 \%$ de B de 6-12 min, retorno a $15 \%$ de B aos 13 min e mantendo por mais 
7 minutos nesta condição para equilibrar a coluna. O fluxo de fase móvel foi de 320 $\mu \mathrm{L} \min ^{-1}$ e a temperatura do forno mantida à $40^{\circ} \mathrm{C}$. As condições do espectrômetro de massas foram: voltagem na fonte de ionização \pm 3000 volts, fluxo de gás nebulizador (nitrogênio) a $12 \mathrm{~L} \cdot \mathrm{min}^{-1}$, temperatura $350{ }^{\circ} \mathrm{C}$ e pressão do nitrogênio a 30 psi. A análise dos compostos fenólicos foi realizada no modo de ionização negativo e a análise de cafeína no modo positivo, na mesma corrida cromatográfica. Inicialmente foi realizada análise scan em ambos os modos e os íons mais abundantes de cada pico selecionados para análise do modo SIM (single ion monitoring).

As identificações do 5-CQA e da cafeína foram realizadas com base no tempo de retenção, espectro de absorção UV e espectro de massas, em comparação com os padrões de referência. A identificação dos demais compostos fenólicos, sem padrão de referência, foi realizada pelos espectros de absorção UV (similaridade com espectro do 5-CQA superior a $90 \%$ ) e de massas, com base nos resultados anteriormente descritos por BASTOS et al. (2007) e JAISWAL et al. (2010). A quantificação foi realizada pelo $\mathrm{DAD}$, através de curva de calibração externa de 5 pontos com o padrão referência: cafeína a $272 \mathrm{~nm}\left(5\right.$ a $\left.40 \mu \mathrm{g} \mathrm{mL} L^{-1}, \mathrm{r}^{2}=0,99998\right)$ e 5-CQA a $324 \mathrm{~nm}\left(5\right.$ a $45 \mu \mathrm{g} \cdot \mathrm{mL}^{-1}, \mathrm{r}^{2}=0$,99995). Os demais compostos fenólicos foram quantificados pela curva do 5-CQA e os resultados somados ao do 5-CQA, para estimativa do teor de fenólicos totais.

A metodologia foi validada com o detector de arranjo de diodos, utilizado para quantificação dos compostos do chá. Foi determinada a precisão das áreas e tempo de retenção do 5-CQA e da cafeína, através da análise de oito replicatas do chá intra-dia (repetibilidade) e inter-dia (precisão intermediária). Os limites de 
detecção (LD) e de quantificação (LQ) foram calculados com base nos parâmetros das curvas de calibração do 5-CQA e cafeína, conforme metodologia proposta pela ICH (International Conference on Harmonisation, 1996) e avaliada por RIBANI et al. (2004): $\mathrm{LD}=3,3 *(s / \mathrm{S})$ e $\mathrm{LQ}=10^{*}(s / \mathrm{S})$, sendo $s$ o desvio padrão residual da equação de regressão e S o coeficiente angular.

\subsection{ANÁLISE ESTATÍSTICA}

\subsubsection{Etapa 1}

Os resultados estão apresentados segundo a estatística descritiva (média \pm erro padrão da média). Foi realizado teste para avaliar a normalidade dos dados (Shapiro-Wilk). Quando assegurada a normalidade, os valores pré-exercício das variáveis massa corporal e glicemia foram analisados por meio de modelos gerais lineares (tendo grupo como fator fixo) e quando encontrado um valor de $\mathrm{F}$ significante, foi aplicado post hoc de Tukey. Os deltas (diferença pós versus préexercício físico) foram comparados por meio da técnica de contrastes ortogonais, quando o valor de $\mathrm{F}$ encontrado foi significante. Os dados das variáveis desempenho físico e diâmetro dos adipócitos foram analisados com modelos gerais lineares (tendo grupo como fator fixo) e quando encontrado valor de F significante, foi aplicado post hoc de Tukey. Quando os dados não atendiam aos critérios para garantir a normalidade (lipólise), eles sofreram transformação logarítimica e foram testados 
para normalidade novamente. Observando a normalidade dos dados, os valores basais transformados foram analisados por meio de modelos gerais lineares (tendo grupo como fator fixo) e quando encontrado um valor de F significante, foi aplicado post hoc de Tukey. Os deltas (diferença entre estimulado com isoproterenol versus basal) foram comparados pela técnica de contrastes ortogonais quando o valor de $\mathrm{F}$ encontrado foi significante. Foi utilizada a correlação linear de Pearson para verificar se havia associação entre as variáveis de interesse.

O nível de significância adotado foi de $\mathrm{p} \leq 0.05$. Para as análises foi utilizado o software estatístico SAS versão 8.02 (SAS Institute, Cary, NC, EUA).

\subsubsection{Etapa 2}

Os resultados estão apresentados segundo a estatística descritiva (média \pm erro padrão da média). Foi realizado teste para avaliar a normalidade dos dados (Shapiro-Wilk). Quando assegurada a normalidade, os valores pré-exercício das variáveis massa corporal e glicemia foram analisados por meio de modelos gerais lineares (tendo grupo como fator fixo) e quando encontrado um valor de $\mathrm{F}$ significante, foi aplicado post hoc de Tukey. Os deltas (diferença pós versus préexercício físico) foram comparados pela técnica de contrastes ortogonais, quando o valor de $\mathrm{F}$ encontrado foi significante. Os dados das variáveis glicogênio muscular, diâmetro dos adipócitos e lactato sanguíneo foram analisados com modelos gerais lineares (tendo grupo como fator fixo) e quando encontrado valor de F significante, foi aplicado post hoc de Tukey. Quando os dados não atendiam aos critérios para 
garantir a normalidade (lipólise), eles sofreram transformação logarítimica e foram testados para normalidade novamente. Observando a normalidade dos dados, os valores pré-exercício transformados foram analisados por meio de modelos gerais lineares (tendo grupo como fator fixo) e quando encontrado um valor de $\mathrm{F}$ significante, foi aplicado post hoc de Tukey. Os deltas (diferença entre estimulado com isoproterenol versus basal) foram comparados pela técnica de contrastes ortogonais, quando o valor de $\mathrm{F}$ encontrado foi significante. Foi utilizada a correlação linear de Pearson para verificar se havia associação entre as variáveis de interesse.

O nível de significância adotado foi de $\mathrm{p} \leq 0.05$. Para as análises foi utilizado o software estatístico SAS versão 8.02 (SAS Institute, Cary, NC, EUA). 


\section{RESULTADOS}

\subsection{ETAPA 1 - EXERCÍCIO FÍSICO EM ESTEIRA, ATÉ A EXAUSTÃO}

\subsubsection{Avaliação do Desempenho Físico}

Na primeira etapa do estudo, onde foi avaliado o desempenho físico, verificou-se que, independente da intervenção à qual o animal foi submetido (placebo, cafeína, café ou chá-mate tostado), não houve diferença estatisticamente significante $(p>0,05)$ entre os grupos com relação ao tempo total de exercício físico até a exaustão (figura 5).

Figura 5. Desempenho físico dos animais submetidos à sessão de exercício em esteira, até a exaustão, após administração de placebo, cafeína, café ou chá-mate

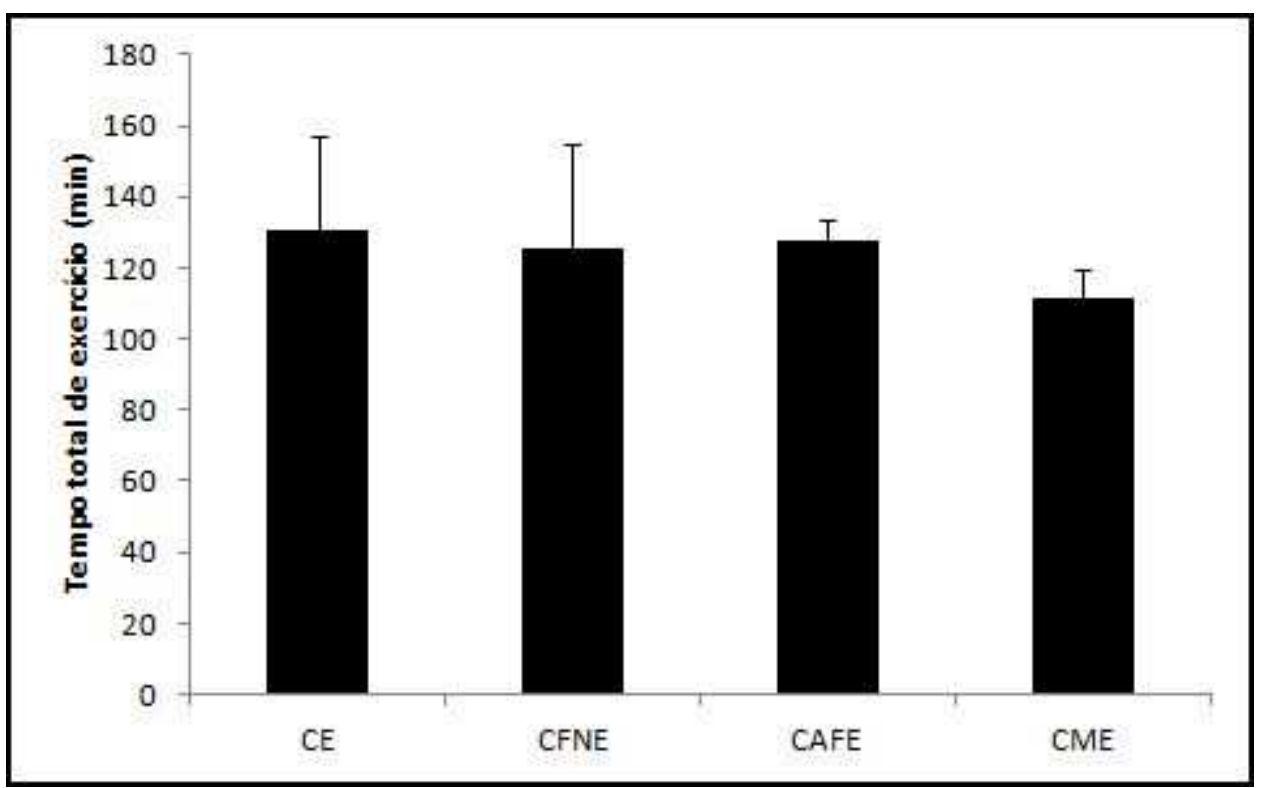

CE (controle exercício), CFNE (cafeína exercício), CAFE (café exercício) e CME (chámate exercício).

Os resultados expressam graficamente a média \pm erro padrão da média ( $n=3 /$ grupo), $\mathrm{p}>0,05$. 


\subsubsection{Avaliação da Massa Corporal Pós versus Pré-Exercício}

Com relação à variável massa corporal, foram comparados os valores referentes às diferenças ( $\Delta$ massa corporal) entre os valores pós-exercício físico versus pré-exercício físico, para cada grupo. Para que isso fosse possível, primeiramente foram verificados os dados de massa corporal pré-exercício físico, não sendo observadas diferenças significantes $(p>0,05)$ entre os grupos. Na tabela 1 estão apresentados os valores de massa corporal pré e pós-exercício físico.

Tabela 1. Massa corporal (g) pré e pós-exercício físico até a exaustão, após administração de placebo, cafeína, café ou chá-mate

\begin{tabular}{c|c|c}
\hline $\begin{array}{c}\text { Grupo } \\
\text { Experimental }\end{array}$ & $\begin{array}{c}\text { Massa Corporal (g) } \\
\text { Pré-Exercício Físico }\end{array}$ & $\begin{array}{c}\text { Massa Corporal (g) } \\
\text { Pós-Exercício Físico }\end{array}$ \\
\hline Controle (C) & $265,1 \pm 30,3$ & $260,9 \pm 29,5$ \\
Controle Exercício (CE) & $282,7 \pm 21,3$ & $270,6 \pm 20,0$ \\
Cafeína Exercício (CFNE) & $277,3 \pm 7,5$ & $261,6 \pm 7,9$ \\
Café Exercício (CAFE) & $276,2 \pm 10,1$ & $258,6 \pm 7,8$ \\
Chá-Mate Exercício CME) & $261,1 \pm 6,8$ & $248,3 \pm 6,9$ \\
\hline
\end{tabular}

Nos animais do grupo C, a massa corporal foi aferida em tempos médios similares aos dos animais submetidos ao exercício.

Os valores representam a média \pm erro padrão da média ( $n=3 /$ grupo), $p>0,05$ (comparação entre os grupos para a variável massa corporal pré-exercício físico).

A massa corporal pós-exercício diminuiu em todos os grupos, quando comparada aos valores pré-exercício. Quando comparados ao grupo C, os valores das diferenças (pós versus pré-exercício) foram significantemente maiores para todos grupos [CE 180\% $(p=0,0165)$, CFNE 273\% $(p=0,0019)$, CAFE 319\% $(p=0,0006)$ e 
CME 204\% ( $\mathrm{p}=0,009)$ ], porém não sendo observadas diferenças $(\mathrm{p}>0,05)$ entre os grupos CE, CFNE, CAFE e CME (Figura 2). Esses dados demonstram que houve uma maior perda de massa corporal para os grupos submetidos ao exercício, independente da intervenção (placebo, cafeína, café ou chá-mate), quando comparados ao grupo controle.

Figura 6. Variação da massa corporal (g) (pós versus pré-exercício físico até a exaustão), após administração de placebo, cafeína, café ou chá-mate

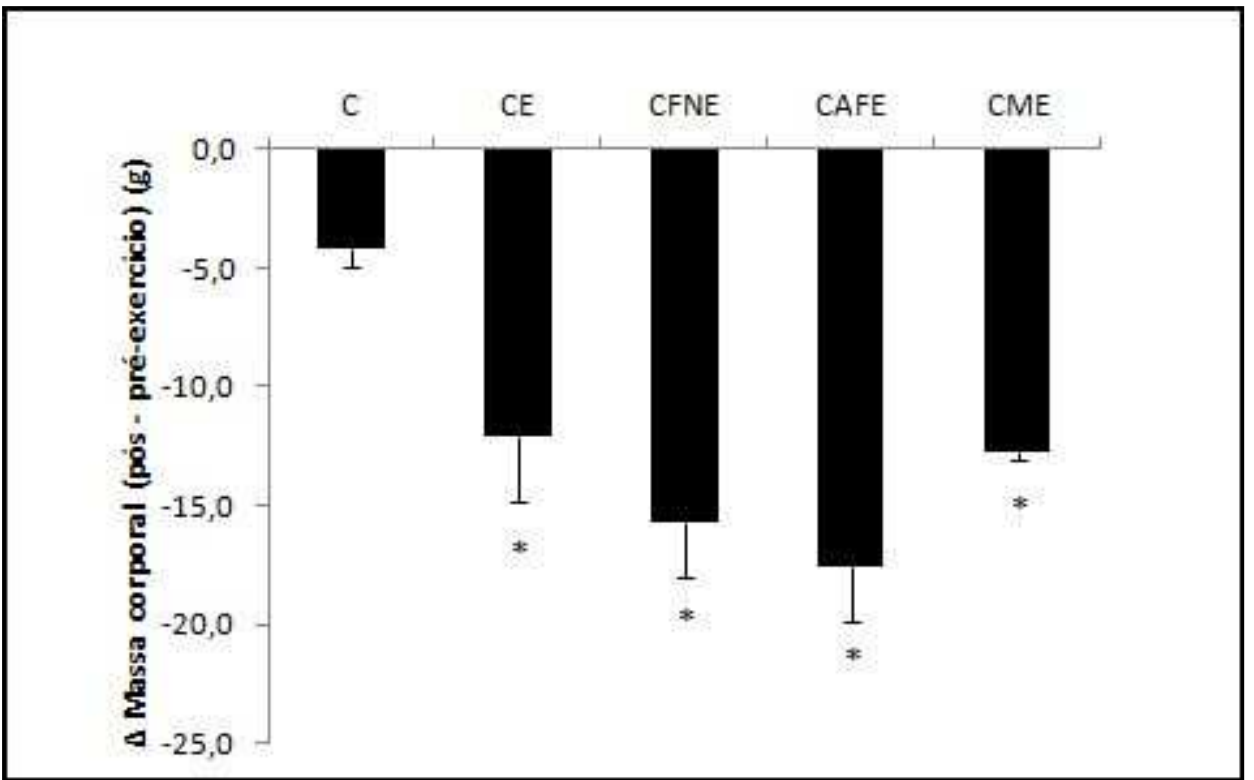

C (controle), CE (controle exercício), CFNE (cafeína exercício), CAFE (café exercício) e CME (chá-mate exercício). Nos animais do grupo C, a massa corporal foi aferida em tempos médios similares aos dos animais submetidos ao exercício.

Os resultados expressam graficamente a média \pm erro padrão da média ( $\mathrm{n}=3$ /grupo).

*Diferença significante vs. grupo $\mathrm{C}(\mathrm{p} \leq 0,05)$. 


\subsubsection{Avaliação da Glicemia Pós versus Pré-Exercício}

Para a variável glicemia, foram comparados os valores referentes às diferenças ( $\Delta$ glicemia) entre os valores pós-exercício físico versus pré-exercício físico, para cada grupo. Para que isso fosse possível, primeiramente foram verificados os dados de glicemia pré-exercício físico, não sendo observadas diferenças $(p>0,05)$ entre os grupos. Na tabela 2 estão apresentados os valores de glicemia pré e pós-exercício físico.

Tabela 2. Glicemia $(\mathrm{mg} / \mathrm{dL})$ pré e pós-exercício físico até a exaustão, após administração de placebo, cafeína, café ou chá-mate

\begin{tabular}{c|c|c}
\hline $\begin{array}{c}\text { Grupo } \\
\text { Experimental }\end{array}$ & $\begin{array}{c}\text { Glicemia (mg/dL) } \\
\text { Pré-Exercício }\end{array}$ & $\begin{array}{c}\text { Glicemia (mg/dL) } \\
\text { Pós-Exercício }\end{array}$ \\
\hline Controle (C) & $83 \pm 8$ & $70 \pm 12$ \\
Controle Exercício (CE) & $93 \pm 2$ & $59 \pm 9$ \\
Cafeína Exercício (CFNE) & $95 \pm 4$ & $53 \pm 9$ \\
Café Exercício (CAFE) & $93 \pm 4$ & $72 \pm 14$ \\
Chá-Mate Exercício (CME) & $94 \pm 8$ & $62 \pm 11$ \\
\hline
\end{tabular}

Nos animais do grupo C, a glicemia foi aferida em tempos médios similares aos dos animais submetidos ao exercício.

Os valores representam a média \pm erro padrão da média ( $n=3 /$ grupo), $p>0,05$ (comparação entre os grupos para a variável glicemia pré-exercício físico). 
Para a variável glicemia (diferença pós versus pré-exercício), figura 7, não foi observada diferença significante entre os grupos experimentais $(p>0,05)$. Foi observada apenas uma tendência para o grupo CFNE apresentar diferença, quando comparado ao grupo $\mathrm{C}(\mathrm{p}=0,068)$.

Figura 7. Variação da glicemia $(\mathrm{mg} / \mathrm{dL})$ (pós versus pré-exercício físico até a exaustão), após administração de placebo, cafeína, café ou chá-mate

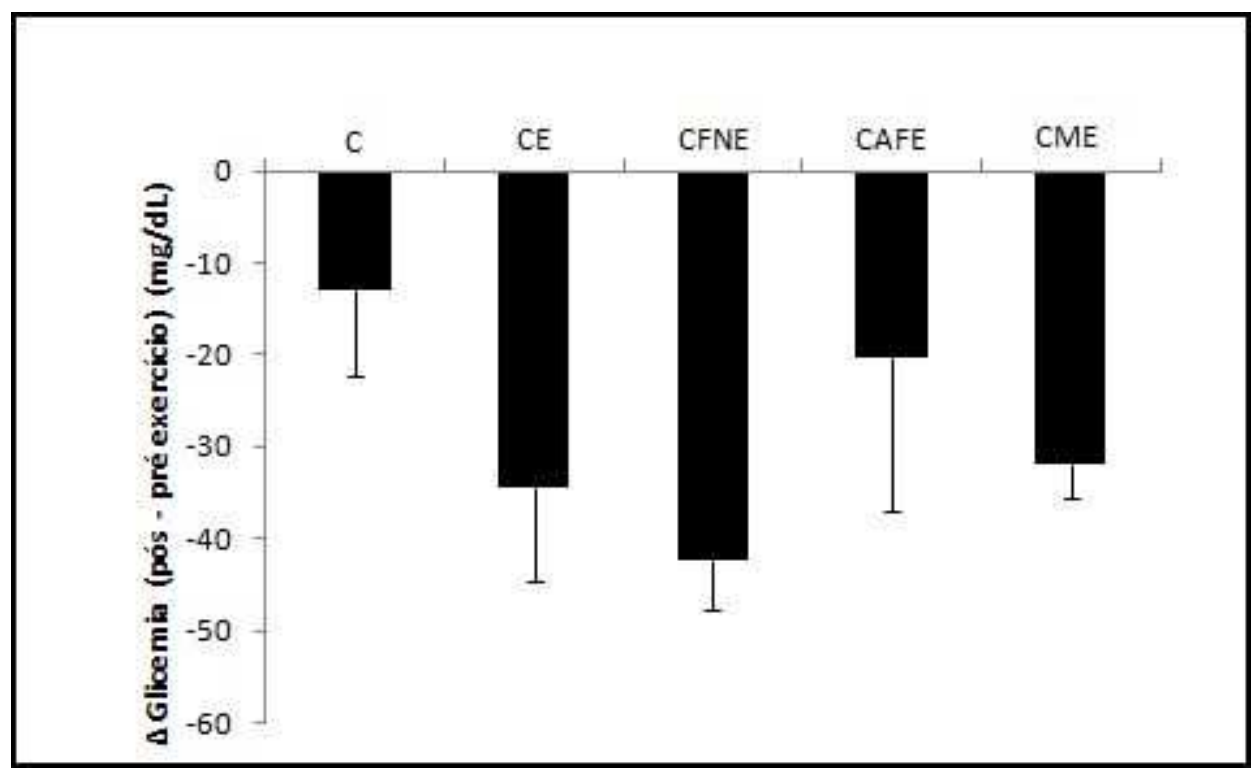

C (controle), CE (controle exercício), CFNE (cafeína exercício), CAFE (café exercício) e CME (chá-mate exercício). Nos animais do grupo C, a glicemia foi aferida em tempos médios similares aos dos animais submetidos ao exercício.

Os resultados expressam graficamente a média \pm erro padrão da média ( $\mathrm{n}=3$ /grupo), $\mathrm{p}>0,05$.

\subsubsection{Atividade Lipolítica}

A taxa de lipólise foi medida por meio da concentração de glicerol liberado por adipócitos isolados. A medida do diâmetro dos adipócitos e a massa adiposa total 
do tecido adiposo periepididimal estão apresentadas na tabela 3. Não houve diferença estatisticamente significante entre os grupos $(\mathrm{p}>0,05)$.

Tabela 3. Diâmetro dos adipócitos $(\mu \mathrm{m})$ pós-exercício físico até a exaustão, realizado após administração de placebo, cafeína, café ou chá-mate

\begin{tabular}{c|c}
\hline Grupo Experimental & Diâmetro dos adipócitos $(\boldsymbol{\mu m})$ \\
\hline Controle & $43,47 \pm 1,29$ \\
Controle Exercício & $44,89 \pm 4,00$ \\
Cafeína Exercício & $44,50 \pm 3,24$ \\
Café Exercício & $51,48 \pm 3,17$ \\
Chá-mate Exercício & $45,73 \pm 1,96$ \\
\hline
\end{tabular}

Nos animais do grupo C, a medida do diâmetro dos adipócitos foi realizada em tempos médios similares aos dos animais submetidos ao exercício.

Os valores representam a média \pm erro padrão da média ( $n=3 /$ grupo), $p>0,05$ (entre os grupos, para cada uma das variáveis).

Foram comparados os valores referentes às diferenças (deltas) entre os valores da lipólise maximamente estimulada com isoproterenol (ISO) versus lipólise basal ou espontânea (BS), para cada grupo. Para que isso fosse possível, primeiramente foram verificados os dados de lipólise basal, não sendo observadas diferenças ( $p>0,05)$ entre os grupos (dados não apresentados).

Foi possível observar que a lipólise estava 92\% mais elevada para o grupo CAFE, quando comparada ao grupo $\mathrm{C}(\mathrm{p}=0,032)$ e que apresentou forte tendência de estar aumentada, quando comparada ao grupo $\mathrm{CE}(\mathrm{p}=0,054)$ (figura 8). 
Figura 8. Efeito da administração de cafeína, café e chá-mate sobre a taxa de lipólise (ISO-BS) (nmol/10 ${ }^{6}$ céls.h $\left.^{-1}\right)$ em adipócitos isolados, após exercício até a exaustão

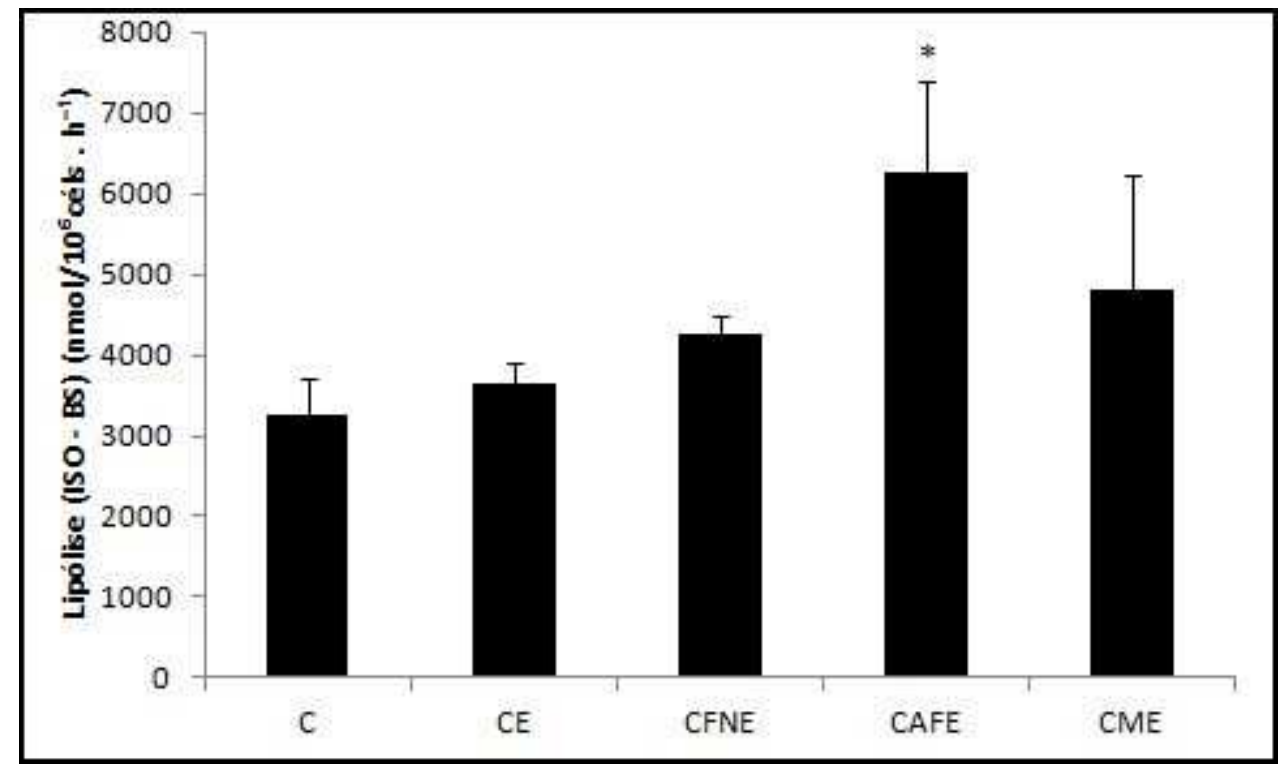

C (controle), CE (controle exercício), CFNE (cafeína exercício), CAFE (café exercício) e CME (chá-mate exercício). Nos animais do grupo C, a taxa de lipólise foi determinada em tempos médios similares aos dos animais submetidos ao exercício.

Os resultados expressam graficamente a média \pm erro padrão da média ( $\mathrm{n}=3 /$ grupo).

*Diferença significante vs. grupo $\mathrm{C}(\mathrm{p} \leq 0,05)$

Não foram encontradas correlações entre as variáveis estudadas na etapa 1.

\subsection{ETAPA 2 - EXERCÍCIO FÍSICO EM ESTEIRA COM DURAÇÃO DE SESSENTA MINUTOS}

\subsubsection{Avaliação da Massa Corporal Pós versus Pré-Exercício}

Com relação à variável massa corporal, foram comparados os valores referentes às diferenças ( $\Delta$ massa corporal) entre os valores pós-exercício físico versus pré-exercício físico, para cada grupo. Para que isso fosse possível, 
primeiramente foram verificados os dados de massa corporal pré-exercício físico, não sendo observadas diferenças $(\mathrm{p}>0,05)$ entre os grupos. $\mathrm{Na}$ tabela 4 estão apresentados os valores de massa corporal pré e pós-exercício físico.

Tabela 4. Massa corporal (g) pré e pós-exercício físico com duração de sessenta minutos, após administração de placebo, cafeína, café ou chá-mate

\begin{tabular}{c|c|c}
\hline $\begin{array}{c}\text { Grupo } \\
\text { Experimental }\end{array}$ & $\begin{array}{c}\text { Massa Corporal (g) } \\
\text { Pré-Exercício }\end{array}$ & $\begin{array}{c}\text { Massa Corporal (g) } \\
\text { Pós-Exercício }\end{array}$ \\
\hline Controle (C) & $333,9 \pm 15,2$ & $330,9 \pm 15,1$ \\
Controle Exercício (CE) & $374,2 \pm 14,1$ & $363,3 \pm 14,2$ \\
Cafeína Exercício (CFNE) & $359,4 \pm 6,0$ & $348,9 \pm 6,0$ \\
Café Exercício (CAFE) & $353,0 \pm 12,9$ & $343,2 \pm 12,4$ \\
Chá-Mate Exercício (CME) & $353,8 \pm 12,6$ & $345,3 \pm 11,8$ \\
\hline
\end{tabular}

Nos animais do grupo C, a massa corporal foi aferida em tempos médios similares aos dos animais submetidos ao exercício. Grupo C ( $\mathrm{n}=8)$, grupos CE, CFNE e CAFE ( $\mathrm{n}=9)$ e grupo CME $(\mathrm{n}=10)$. Os valores representam a média \pm erro padrão da média, $p>0,05$ (comparação entre os grupos para a variável massa corporal pré-exercício físico).

A massa corporal pós-exercício diminuiu em todos os grupos, quando comparada aos valores pré-exercício. Quando comparados ao grupo C, os valores das diferenças (pós versus pré-exercício) foram significantemente maiores para todos grupos [CE 263\% $(p<0,0001)$, CFNE 263\% $(p=0,0001)$, CAFE 230\% $(p=0,0002)$ e CME 183\% ( $p=0,0014)$ ], porém não sendo observadas diferenças $(p>0,05)$ entre os grupos CE, CFNE, CAFE e CME (Figura 9). Esses dados demonstram que houve uma maior perda de massa corporal para os grupos submetidos ao exercício, independente da intervenção (placebo, cafeína, café ou chá-mate), quando comparados ao grupo controle. 
Figura 9. Variação da massa corporal (g) (pós versus pré-exercício físico com duração de sessenta minutos), após administração de placebo, cafeína, café ou chámate

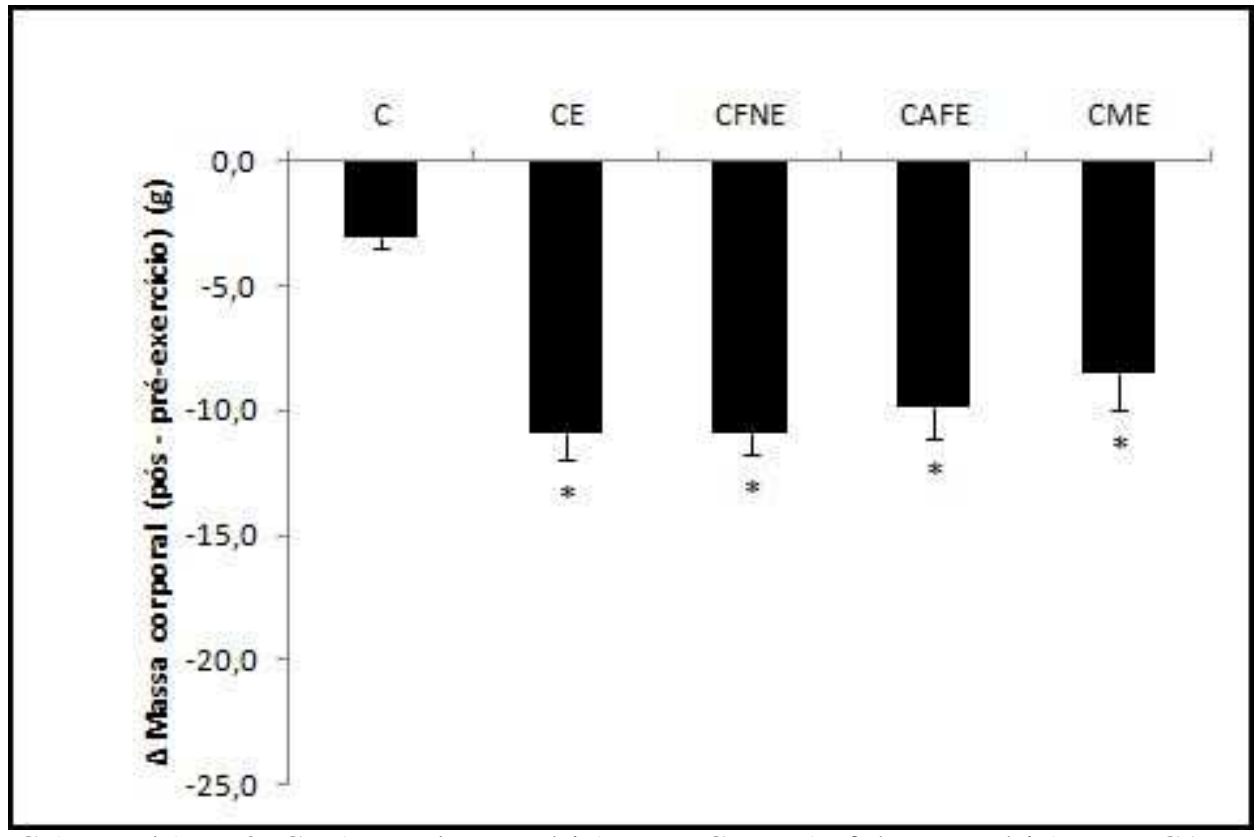

C (controle), $n=8 ;$ CE (controle exercício), n=9; CFNE (cafeína exercício), n=9; CAFE (café exercício), n=9; CME (chá-mate exercício), $\mathrm{n}=10$. Nos animais do grupo $\mathrm{C}$, a massa corporal foi aferida em tempos médios similares aos dos animais submetidos ao exercício.

Os resultados expressam graficamente a média \pm erro padrão da média. *Diferença significante vs. grupo $\mathrm{C}(\mathrm{p} \leq 0,05)$

\subsubsection{Avaliação da Glicemia Pós versus Pré-Exercício}

Para a variável glicemia, foram comparados os valores referentes às diferenças ( $\Delta$ glicemia) entre os valores pós-exercício físico versus pré-exercício físico, para cada grupo. Para que isso fosse possível, primeiramente foram verificados os dados de glicemia pré-exercício físico, não sendo observadas diferenças $(p>0,05)$ entre os grupos. Na tabela 5 estão apresentados os valores de glicemia pré e pós-exercício físico. 
Tabela 5. Glicemia $(\mathrm{mg} / \mathrm{dL})$ pré e pós-exercício físico com duração de sessenta minutos, após administração de placebo, cafeína, café ou chá-mate

\begin{tabular}{c|c|c}
\hline $\begin{array}{c}\text { Grupo } \\
\text { Experimental }\end{array}$ & $\begin{array}{c}\text { Glicemia }(\mathbf{m g} / \mathbf{d L}) \\
\text { Pré-Exercício }\end{array}$ & $\begin{array}{c}\text { Glicemia (mg/dL) } \\
\text { Pós- Exercício }\end{array}$ \\
\hline Controle (C) & $126 \pm 9$ & $117 \pm 11$ \\
Controle Exercício (CE) & $126 \pm 5$ & $108 \pm 13$ \\
Cafeína Exercício (CFNE) & $106 \pm 9$ & $127 \pm 7$ \\
Café Exercício (CAFE) & $123 \pm 6$ & $124 \pm 9$ \\
Chá-Mate Exercício (CME) & $108 \pm 6$ & $124 \pm 8$ \\
\hline
\end{tabular}

Nos animais do grupo C, a glicemia foi aferida em tempos médios similares aos dos animais submetidos ao exercício.

Os valores representam a média \pm erro padrão da média. Grupo $C(n=7)$, grupos CE, CFNE $(n=8)$, grupo $\operatorname{CAFE}(n=9)$ e grupo CME $(n=10)$. p $>0,05$ (comparação entre os grupos para a variável glicemia pré-exercício físico).

Para a variável glicemia (diferença pós versus pré-exercício), foi observada diferença significante para o grupo CFNE quando comparado aos grupos $\mathrm{C}$ e CE, $(\mathrm{p}=0,047 \mathrm{e} \mathrm{p}=0,007$, respectivamente). Observou-se que a diferença entre a glicemia pós versus pré-exercício no grupo CFNE foi $343 \%$ maior, quando comparada ao grupo C e $220 \%$ maior, quando comparada ao grupo CE. Comportamento semelhante foi observado para o grupo CME, sendo a diferença da glicemia (pós versus préexercício) $179 \%$ maior ( $\mathrm{p}=0,023$ ), quando comparada ao grupo CE (figura 10). Observando os dados, é possível notar que, em média, os valores de glicemia pósexercício aumentaram nos grupos CFNE e CME, quando comparados aos valores pré-exercício, enquanto que nos grupos $\mathrm{C}$ e $\mathrm{CE}$, houve diminuição da glicemia na mesma situação, parecendo ter se mantido estável no grupo CAFE. 
Figura 10. Variação da glicemia $(\mathrm{mg} / \mathrm{dL})$ (pós versus pré-exercício físico com duração de sessenta minutos), após administração de placebo, cafeína, café ou chámate

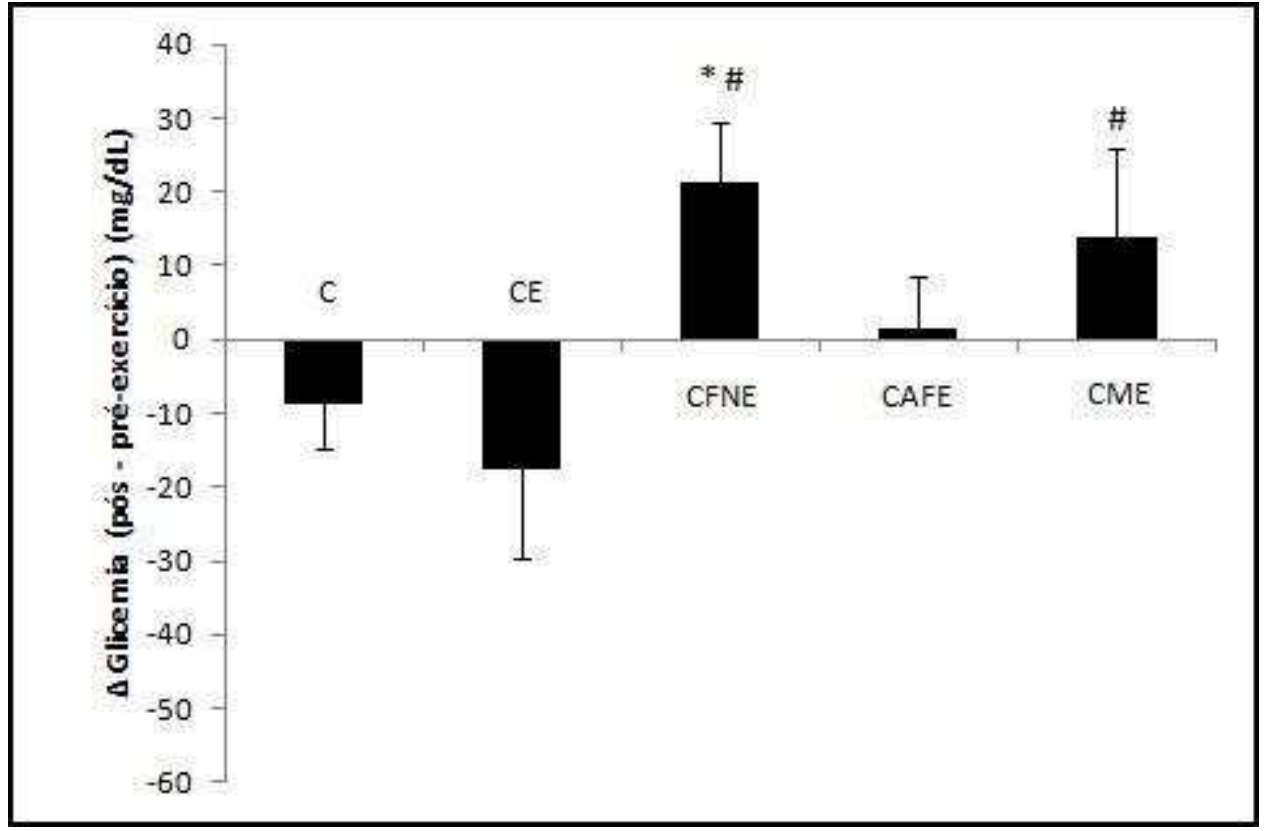

$\mathrm{C}$ (controle), $\mathrm{n}=7$; CE (controle exercício), n=8; CFNE (cafeína exercício), n=8; CAFE (café exercício), n=9; CME (chá-mate exercício) $\mathrm{n}=10$. Nos animais do grupo $\mathrm{C}$, a glicemia foi aferida em tempos médios similares aos dos animais submetidos ao exercício.

Os resultados expressam graficamente a média \pm erro padrão da média. * Diferença significante vs. grupo $\mathrm{C}(\mathrm{p} \leq 0,05)$ e \# diferença significante vs. grupo $\mathrm{CE}(\mathrm{p} \leq 0,05)$.

\subsubsection{Atividade Lipolítica}

Assim como na etapa 1, na etapa 2 a taxa de lipólise também foi medida por meio da concentração de glicerol liberado por adipócitos isolados. A medida do diâmetro dos adipócitos está apresentada na tabela 6. Não houve diferença estatisticamente significante entre os grupos $(p>0,05)$. 
Tabela 6. Diâmetro dos adipócitos ( $\mu \mathrm{m})$ após sessão de exercício físico com duração de sessenta minutos

\begin{tabular}{c|c}
\hline Grupo & Diâmetro dos adipócitos $(\boldsymbol{\mu m})$ \\
\hline Controle & $80,51 \pm 3,74$ \\
Controle Exercício & $79,12 \pm 5,67$ \\
Cafeína Exercício & $73,25 \pm 2,68$ \\
Café Exercício & $80,82 \pm 3,75$ \\
Chá-mate Exercício & $72,79 \pm 1,42$ \\
\hline
\end{tabular}

Nos animais do grupo C, a medida do diâmetro dos adipócitos foi realizada em tempos médios similares aos dos animais submetidos ao exercício.

Os valores representam a média \pm erro padrão da média. Grupo C e CFNE (n=6), grupo CE, CAFE e CME (n=5), $p>0,05$.

Foram comparados os valores referentes às diferenças (deltas) entre os valores da lipólise maximamente estimulada com isoproterenol (ISO) versus lipólise basal ou espontânea (BS), para cada grupo. Para que isso fosse possível, primeiramente foram verificados os dados de lipólise basal, não sendo observadas diferenças ( $p>0,05)$ entre os grupos (dados não apresentados).

Foi possível observar que a taxa de lipólise no grupo CFNE foi $150 \%$ maior, quando comparada ao grupo $\mathrm{C}(\mathrm{p}=0,02)$ e $51 \%$ maior, quando comparada ao grupo CE ( $\mathrm{p}=0,018)$. O grupo CAFE também apresentou taxa lipolítica 233\% maior, quando comparada ao grupo $\mathrm{C}(\mathrm{p}=0,0073)$ e $101 \%$ maior, quando comparada ao grupo $\mathrm{CE}(\mathrm{p}=0,007)$ (figura 11). 
Figura 11. Efeito da administração de cafeína, café e chá-mate sobre a taxa de lipólise (ISO-BS) (nmol/10 $10^{6}$ céls. $\left.^{-1}\right)$ em adipócitos isolados, após exercício com duração de sessenta minutos

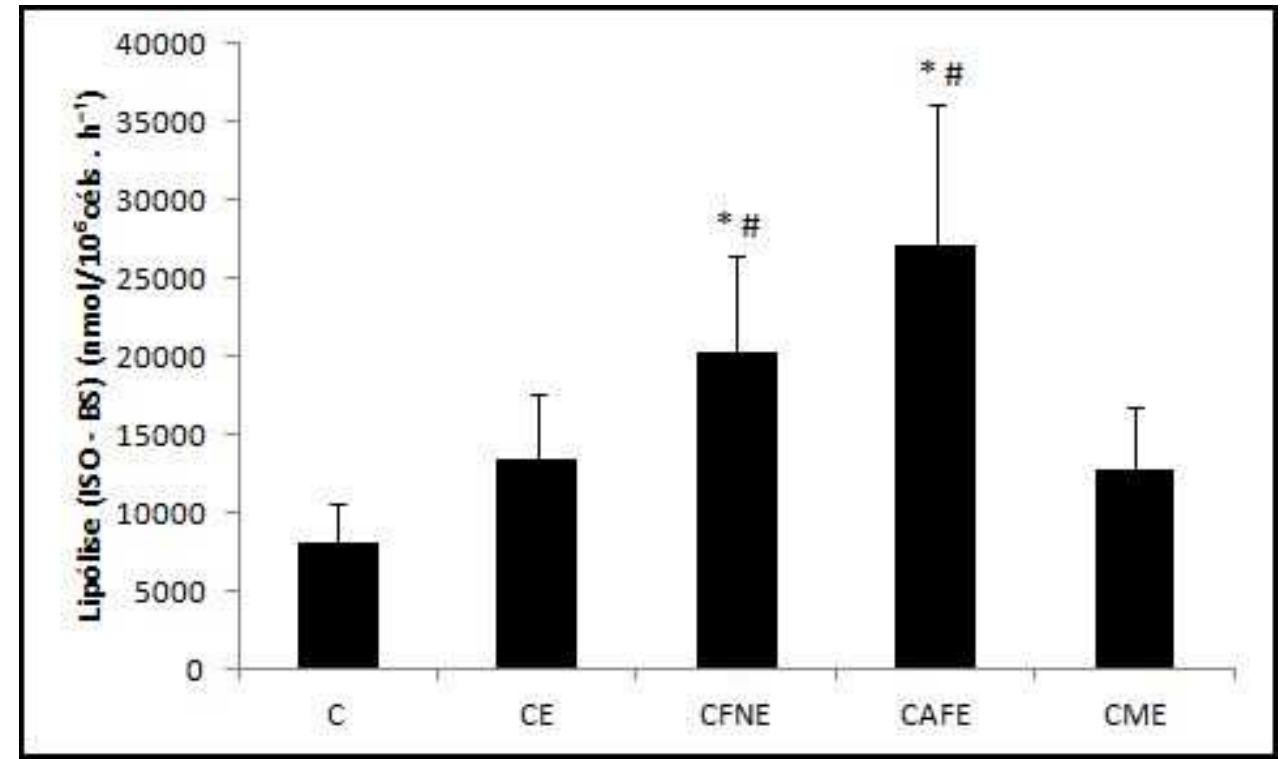

C (controle), $\mathrm{n}=4$; CE (controle exercício), $\mathrm{n}=6$; CFNE (cafeína exercício), $\mathrm{n}=6$; CAFE (café exercício), $\mathrm{n}=5$; CME (chá-mate exercício) $\mathrm{n}=5$. Nos animais do grupo $\mathrm{C}$, a taxa de lipólise foi determinada em tempos médios similares aos dos animais submetidos ao exercício.

Os resultados expressam graficamente a média \pm erro padrão da média. * Diferença significante vs. grupo $\mathrm{C}(\mathrm{p} \leq 0,05)$ e \# diferença significante vs. grupo $\mathrm{CE}(\mathrm{p} \leq 0,05)$.

\subsubsection{Avaliação do Conteúdo de Glicogênio Muscular}

Quando comparados os valores referentes ao conteúdo de glicogênio muscular (sóleo) dos animais, não foram observadas diferenças estatisticamente significantes entre os grupos ( $p>0,05)$ (figura 12). 
Figura 12. Efeito da administração de cafeína, café e chá-mate sobre o conteúdo de glicogênio muscular (sóleo) (mg/g) após exercício com sessenta minutos de duração

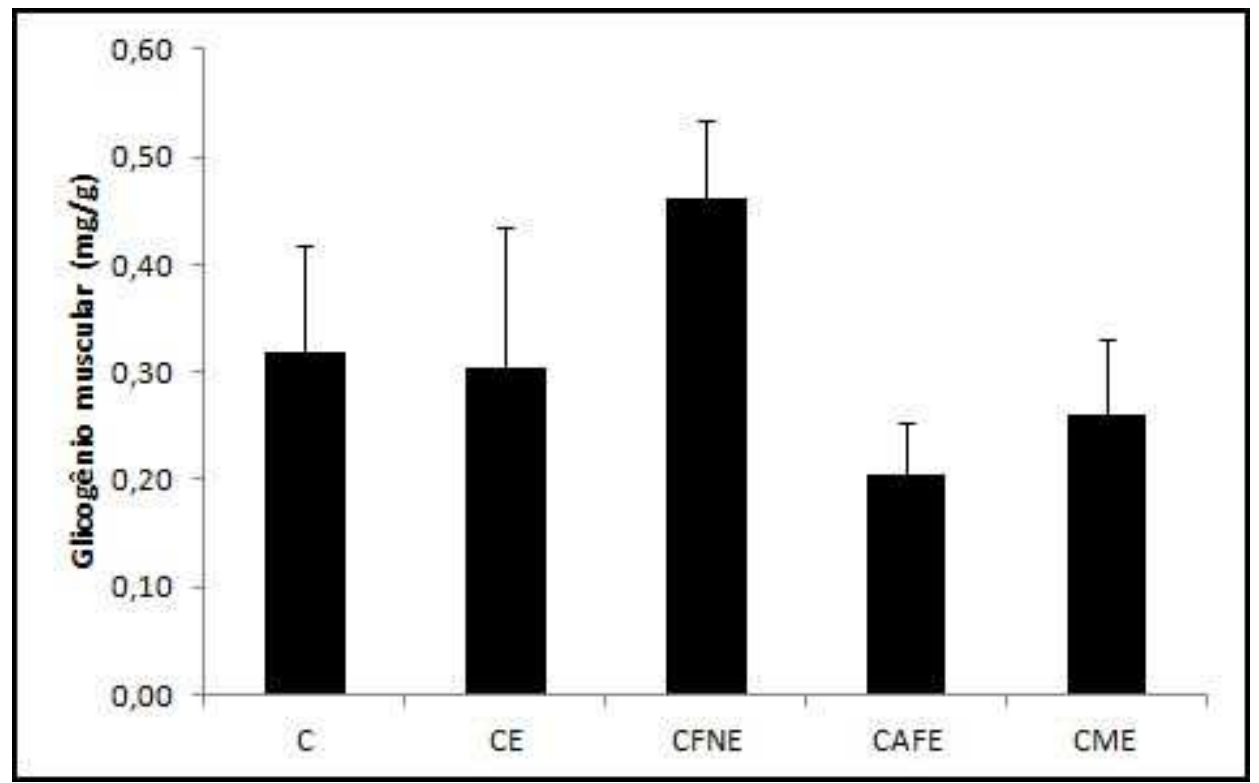

C (controle), $n=5$; CE (controle exercício), $n=5$; CFNE (cafeína exercício), n=6; CAFE (café exercício), $\mathrm{n}=6$; CME (chá-mate exercício), $\mathrm{n}=7$. Nos animais do grupo $\mathrm{C}$, o conteúdo de glicogênio muscular foi determinado em tempos médios similares aos dos animais submetidos ao exercício.

Os resultados expressam graficamente a média \pm erro padrão da média, $p>0,05$.

\subsubsection{Avaliação da Concentração Sanguínea de Lactato}

Imediatamente após o término da sessão de exercício físico com duração de sessenta minutos, foi aferida a concentração sanguínea de lactato. Não houve diferenças estatisticamente significantes $(\mathrm{p}>0,05)$ (tabela 7). 
Tabela 7. Lactato (mmol/L) imediatamente após a sessão de exercício físico com duração de sessenta minutos

\begin{tabular}{c|c}
\hline Grupo Experimental & Lactato (mmol/L) pós-exercício \\
\hline Controle (C) & $2,4 \pm 0,3$ \\
Controle Exercício (CE) & $2,7 \pm 0,5$ \\
Cafeína Exercício (CFNE) & $2,4 \pm 0,3$ \\
Café Exercício (CAFE) & $2,4 \pm 0,3$ \\
Chá-mate Exercício (CME) & $2,2 \pm 0,3$ \\
\hline
\end{tabular}

Os valores representam a média \pm erro padrão da média, p>0,05.

Não foram encontradas correlações entre as variáveis estudadas na etapa 2.

\subsection{CONCENTRAÇÃO DE COMPOSTOS FENÓLICOS E DE CAFEÍNA NO CAFÉ E NO CHÁ-MATE}

A concentração $(\mathrm{mg} / \mathrm{g})$ dos fitoquímicos avaliados no café solúvel e no chámate tostado solúvel utilizados no presente estudo, encontram-se descritas nas tabelas 8 e 9, respectivamente. A partir dos resultados obtidos, é possível observar que o café solúvel contém praticamente o dobro da concentração de cafeína (mg/g), quando comparado ao chá-mate tostado solúvel $(28,57 \mathrm{mg} / \mathrm{g}$ e $15,03 \mathrm{mg} / \mathrm{g}$, respectivamente). Em contrapartida, a concentração de fenólicos totais é inferior, praticamente três vezes mais baixa no café solúvel, quando comparado ao chá-mate tostado solúvel (31,81 mg/g e 106,38 mg/g). 
Tabela 8. Concentração $(\mathrm{mg} / \mathrm{g})$ dos principais fitoquímicos presentes no café solúvel (Coffea arabica)

\begin{tabular}{c|c}
\hline Fitoquímico & Concentração $(\mathbf{m g} / \mathbf{g})$ \\
\hline 5-CQA & $8,18 \pm 0,16$ \\
Cafeína & $28,57 \pm 0,37$ \\
Outros fenólicos & $23,62 \pm 0,45$ \\
Fenólicos Totais & $31,81 \pm 0,55$ \\
\hline
\end{tabular}

Tabela 9. Concentração $(\mathrm{mg} / \mathrm{g})$ dos principais fitoquímicos presentes no chá-mate tostado solúvel (Ilex paraguariensis)

\begin{tabular}{c|c}
\hline Fitoquímico & Concentração $(\mathbf{m g} / \mathbf{g})$ \\
\hline 5-CQA & $28,11 \pm 0,02$ \\
Cafeína & $15,03 \pm 0,02$ \\
Outros fenólicos & $78,27 \pm 0,30$ \\
Fenólicos Totais & $106,38 \pm 0,29$ \\
\hline
\end{tabular}




\section{DISCUSSÃO}

A Organização Mundial da Saúde (OMS) tem incentivado, desde a década de setenta, o estudo de algumas plantas, tradicionalmente reconhecidas como medicinais, com o objetivo de avaliar cientificamente os benefícios da utilização de medicamentos fitoterápicos e, ao mesmo tempo, de conhecer os riscos de seu uso indevido (LOGUERCIO, 2005). Muitos centros de pesquisas, em diversos países, vêm desenvolvendo estudos sobre as propriedades farmacológicas de uma grande variedade de plantas. No entanto, em sua maioria, ainda faltam evidências laboratoriais e clínicas sobre a eficácia e a segurança das mesmas, tanto em animais, como em seres humanos. Os supostos benefícios atribuídos a elas devem-se ainda, principalmente, à informações empíricas e subjetivas do conhecimento popular e do folclore tradicional (YUNES \& CECHINEL FILHO, 2001).

Além das plantas medicinais, outros produtos, em sua maioria também de origem vegetal e que fazem parte da dieta humana habitual (que não são classificados como ervas medicinais pela Agência Nacional de Vigilância Sanitária - ANVISA), podem fornecer, além dos macronutrientes e micronutrientes essenciais, alguns outros compostos químicos. Esses compostos podem estar presentes nas frutas, legumes, verduras, cereais, dentre outros alimentos e são denominados compostos bioativos ou fitoquímicos e desempenham diversos papéis em benefício da saúde humana (CARRATO E SANZINE, 2005). Alguns dos fitoquímicos consumidos em larga escala pela população mundial é a cafeína, presente em alimentos e bebidas, como no café, por exemplo. Em dados divulgados recentemente (ABIC, 2011), 
houve a confirmação de que o café é a segunda bebida mais consumida pela população brasileira acima dos 15 anos, perdendo apenas para a água, estando à frente até mesmo dos refrigerantes. Devido sua grande importância, o café foi e ainda vem sendo alvo de diversos estudos, porém quando se tenta relacionar seu consumo à prevenção de algumas doenças, ainda não há consenso sobre seus reais benefícios (HAMER, 2006; TAYLOR e DEMMIG-ADAMS, 2007).

No caso de outros produtos que também possuem a cafeína em sua composição, como é o caso do chá-mate (e, assim como o café, possui outros compostos fitoquímicos, como os fenólicos, por exemplo), embora seu consumo seja bastante típico em alguns países e regiões específicas, ainda há uma quantidade relativamente pequena de estudos que se propuseram a investigar os efeitos atribuídos a ele, principalmente àqueles que constam da literatura popular e dizem respeito à sua utilização pelos povos indígenas. Com base nessas informações, observa-se a importância da investigação de alternativas, presentes na própria alimentação, que pudessem auxiliar na prevenção de alguns problemas que afetam a saúde humana.

Sabendo-se que a prevenção do sobrepeso e da obesidade poderia prevenir o risco de diversas doenças, principalmente as crônicas não transmissíveis (WHO, 1998) e que a cafeína tem sido utilizada como auxiliar no dispêndio energético (ALTIMARI, 2000), uma vez que ela potencializa os efeitos termogênicos induzidos pelo estímulo simpático (como ocorre no exercício físico, por exemplo), este estudo se propôs a fazer uma comparação, até então, inédita na literatura. Ao investigar se os efeitos do café e do chá-mate tostado seriam similares aos efeitos da cafeína (isolada) no metabolismo de ratos Wistar (submetidos a dois diferentes protocolos de 
exercício físico aeróbio agudo em esteira - até a exaustão e com duração de sessenta minutos), estabelecemos alguns resultados ainda não discutidos anteriormente.

Como apontam alguns estudos, o exercício físico agudo tem apresentado efeitos sobre parâmetros fisiológicos, como no sistema imunológico, na concentração de lipídeos sanguíneos, no metabolismo da glicose e na utilização dos substratos energéticos (ROWBOTTOM e GREEN, 2000; THOMPSON, 2001). No presente trabalho, ao ser utilizado um protocolo de exercício físico aeróbio, até a exaustão, também foi possível averiguar se o chá-mate aumentaria a resistência física à fadiga (preliminarmente em animais), como se supõe empiricamente.

Nas últimas duas décadas, diversas revisões foram publicadas tendo como objetivo relatar os efeitos ergogênicos decorrentes da utilização de cafeína, em vários protocolos de exercícios diferentes (SPRIET e HOWLETT, 2000; GRAHAM, 2001). Alguns deles demonstraram que a cafeína pode aumentar o tempo até a exaustão, durante exercício submáximos, por aproximadamente 30 a 60 min. ALTIMARI et al. (2000) fez uma excelente revisão sobre o tema.

Na etapa 1 do presente estudo, em que os animais realizaram uma sessão aguda de exercício até a exaustão, a 70\% da velocidade máxima, não foi possível observar nenhuma diferença estatisticamente significante entre os grupos experimentais com relação ao desempenho físico, medido através do tempo total de exercício até a exaustão (TE). Esses resultados, obtidos por meio do modelo proposto, demonstraram que, tanto a intervenção com água (grupos $\mathrm{C}$ e $\mathrm{CE}$ ), quanto a intervenção com cafeína ( $7 \mathrm{mg} / \mathrm{kg}$ de massa corporal, grupo CFNE), café (grupo CAFE) ou chá-mate tostado (grupos CME), essas duas últimas contendo 
aproximadamente $7 \mathrm{mg}$ de caféina/kg de massa corporal), não afetaram o tempo total de exercício, que foi, em média, de 124 min para os grupos testados.

O interesse nos possíveis efeitos da cafeína como recurso ergogênico durante exercícios de longa duração teve início, como já citado anteriormente, com três trabalhos de COSTILL et al., ainda na década de setenta, nos EUA (COSTILL et al., 1978; IVY et al., 1979; ESSING et al., 1980). No primeiro estudo foram investigados os efeitos da ingestão de 330mg de cafeína, uma hora antes da sessão de exercício em bicicleta ergométrica, a $80 \% \mathrm{VO}_{2}$ max, realizado até a exaustão. Os sujeitos que ingeriram cafeína apresentaram um aumento de 19,5\% no tempo de exaustão (90.2min, grupo cafeína versus 75,5min, grupo placebo) (COSTILL et al., 1978). No segundo estudo do grupo, IVY et al. (1979) demonstraram que 250mg de cafeína estava associada a um aumento de $7 \%$ na quantidade de trabalho produzida em duas horas de exercício em cicloergômetro. Estes estudos deram início a uma série de trabalhos que, posteriormente, também estudaram os efeitos da cafeína e/ou do café sobre o desempenho e metabolismo durante diferentes protocolos de exercício físico.

Grande parte dos estudos que avaliaram os efeitos da ingestão da cafeína e seus efeitos sobre o desempenho no exercício físico foi realizada com atletas ou com indivíduos fisicamente ativos e, além disso, alguns destes estudos utilizaram o cicloergômetro e não a esteira rolante (COSTILL et al., 1978, GRAHAM e SPRIET, 1991, GRAHAM et al., 1998, SILVEIRA et al., 2004). As diferentes doses de cafeína administradas em cada estudo poderiam também influenciar as diferenças nos resultados encontrados, embora PASMAN et al. (1995), ao testarem diferentes doses de cafeína $(5,9$ e $13 \mathrm{mg} / \mathrm{kg})$, apesar de observarem um aumento significativo no desempenho dos grupos suplementados, (quando comparados ao placebo) não 
tenham encontrado diferenças significantes nos efeitos, quando comparadas as três doses.

GRAHAM et al. (1998) investigaram os efeitos da ingestão da cafeína e do café em atletas treinados perceberam que, quando a cafeína era ingerida pura, havia um aumento significativo no tempo total de exercício, diferente de quando a mesma era ingerida através do café. Os autores sugeriram que outras substâncias contidas no café poderiam exercer ação inibitória aos efeitos causados pela cafeína, efeito não observado no presente trabalho.

Ao investigarem os efeitos da suplementação de cafeína em indivíduos não treinados (sedentários), tanto ALVES et al. (1995), quanto KAMINSKY et al. (1998), não encontraram diferenças significantes entre os grupos que haviam ingerido a substância (10 mg/kg e doses de 243-330 mg, respectivamente), corroborando com os resultados encontrados por nosso grupo. Mais recentemente, BRUNETTO et al. (2010), ao estudarem indivíduos não atletas, compararam os efeitos agudos da intervenção de três bebidas: café descafeinado com adoçante (placebo), café com açúcar e café com adoçante (estes com o equivalente a $5 \mathrm{mg}$ de cafeína/kg de massa corporal). Após exercício realizado em esteira, até a exaustão, não foram observadas diferenças significantes no tempo de exaustão entre os grupos. Os autores, em sua discussão, apontam como um dos fatores que poderiam ter influenciado a não encontrarem diferenças entre os grupos, a ingestão das bebidas trinta minutos antes do início do exercício e não sessenta minutos antes, como na maioria dos estudos disponíveis. Apesar desta hipótese não vir de encontro ao presente estudo (afinal a intervenção foi feita em pouco mais de quarenta e cinco minutos antes do início do exercício, considerando-se que a foram utilizados 
aproximadamente mais dez minutos para aferição da massa corporal e glicemia), também pôde-se observar uma limitação com relação ao protocolo escolhido. Por se tratar de uma sessão aguda, onde não há as adaptações dos sistemas metabólico e músculo-articular decorrentes do treinamento físico, observamos que talvez este não seja o protocolo mais adequado, que seria aquele em que apenas as variáveis de interesse poderiam constituir uma limitação para o encerramento da sessão de exercício. Pode ser notado, ao final da sessão de exercício até a exaustão que, para a maioria dos animais, havia um sofrimento talvez maior, podendo ter sido ocasionado em decorrência do tempo em que permaneceram em exercício. Por não haver a adaptação da pele das patas dos animais e não haver nenhum tipo de proteção para as mesmas, ao final da sessão de exercício elas se encontravam machucadas, podendo também ter sido, juntamente a outros fatores, um dos limitadores à continuidade do exercício, embora tenha sido considerado elevada a média de tempo de exercício para todos os grupos.

De acordo com o esperado, não foram encontradas diferenças significantes entre a massa corporal dos animais (pós versus pré-exercício), quando os grupos suplementados com cafeína (CFNE), café (CAFE) e chá-mate tostado (CME) foram comparados ao grupo controle exercício (CE). Foram encontradas diferenças para todos os grupos, apenas quando foram comparados ao grupo controle (C). O mesmo comportamento foi observado no exercício até a exaustão e também no exercício com sessenta minutos de duração, em que os grupos submetidos ao exercício apresentaram em média uma redução de 14,6 g e 10,0 g, respectivamente, quando comparados ao grupo C, que apresentou uma redução de 4,2 g e 3,0 g, respectivamente para cada etapa. 
Embora esteja bem estabelecido na literatura que a cafeína apresenta efeitos diuréticos (SAWYNOK e YAKSH, 1993), poderia equivocadamente ser afirmado que a ingestão da mesma, previamente à realização de exercícios físicos, poderia ocasionar uma maior desidratação (por consequência de uma maior perda de massa corporal), podendo também comprometer o desempenho. Essa hipótese só não pode ser confirmada por ser de conhecimento que os efeitos diuréticos da cafeína em repouso são decorrentes de sua ação nos túbulos renais, inibindo ou mesmo bloqueando a reabsorção dos solutos, resultando assim em um maior volume de água eliminado através da urina. Durante o exercício físico, ocorre o aumento da liberação de catecolaminas, que estimulam a reabsorção dos solutos e, consequentemente, há uma maior retenção de água pelos rins, o que atenua os efeitos contrários da cafeína, atenuando assim os efeitos diuréticos (WEMPLE et al., 1997).

Embora os resultados obtidos (para as variáveis estudadas) entre ambas as etapas (1 e 2) não tenham sido submetidos à análise estatística, pois não constituía dos objetivos deste trabalho se estabelecer comparações entre os diferentes protocolos de exercício, e, portanto, não sendo possível afirmar que os resultados possuem diferenças significantes, pôde-se notar na etapa 1 que a perda de massa corporal foi superior àquela verificada na etapa 2 , o que poderia ser explicado pelo fato de os animais, quando submetidos a um maior tempo de exercício sem a adequada hidratação, perderiam mais massa corporal ao longo do mesmo. Esta diferença poderia ser potencializada, tendo em vista a diferença de massa corporal entre os animais nas duas etapas, devido às idades com as quais iniciaram o experimento (8 e 12 semanas aproximadamente, respectivamente etapas 1 e 2). 
Para que seja possível a realização de um trabalho muscular, é necessário haver concentrações adequadas e suficientes de energia química na forma de ATP. No metabolismo anaeróbio, que ocorre sem ser necessária a presença de oxigênio e tem seu predomínio em esforços de alta intensidade e curta duração, predominantemente os carboidratos (glicose e glicogênio) são utilizados como substratos energéticos. Este sistema de geração de energia, denominado glicólise anaeróbia, tem como principal característica a produção de ATP por meio dessa via metabólica. Nos exercícios de média a longa duração, com intensidade moderada, o sistema predominante é o oxidativo, ou seja, as reações metabólicas ocorrem na presença do oxigênio e isso implica diretamente no tipo de substrato e na via metabólica com que o ATP é ressintetizado. O metabolismo aeróbio também utiliza as gorduras (AGL) e, em casos de trabalho muscular extremo, onde as exigências energéticas são extremamente elevadas (exercício até a exaustão, por exemplo) e o conteúdo de glicogênio muscular e glicose sanguínea estão baixos, as proteínas são degradadas mais intensamente, disponibilizando aminoácidos para o organismo. Os aminoácidos são degradados (desaminação) fornecendo cetoácidos que são convertidos em glicose ou oxidados no Ciclo de Krebs, sendo que este processo é mais eficiente em indivíduos treinados (ROBERGS, 2002).

A produção de energia por meio da via aeróbia é resultante do produto final de um processo complexo de reações que ocorrem no interior das mitocôndrias das células musculares, com participação de enzimas oxidativas, que leva à oxidação da glicose e dos AGL em moléculas de ATP, dióxido de carbono e água.

Segundo SJODIN e JACOBS (1981) a intensidade do exercício pode ser estimada pela determinação da concentração sanguínea de lactato, que seria um 
marcador da intensidade de esforço, uma vez que a concentração sanguínea de lactato elevada representaria que a energia, na forma de ATP, estaria sendo fornecida predominantemente por meio da glicólise anaeróbia e não por meio do metabolismo oxidativo.

No presente estudo, pôde-se confirmar que, na etapa 2, os animais se exercitaram na mesma intensidade relativa de esforço (embora isso tenha sido previsto anteriormente, afinal, como citado anteriormente, todos os animais foram submetidos individualmente ao teste de esforço máximo para poder obter sua intensidade relativa de esforço). Após aferição da concentração sanguínea de lactato, não foram observadas diferenças significativas entre os grupos que, em média, apresentaram valores 2,4 $\mathrm{mmol} / \mathrm{L}$ para esta variável. Admite-se que, o valor semelhante obtido para o grupo $\mathrm{C}$ com relação aos demais grupos que realizaram o exercício em esteira, pode ser atribuído ao fato de que os animais não ficarem completamente em repouso dentro da caixa e, também por estarem expostos ao mesmo ambiente e condições semelhantes, pequenas diferenças que possivelmente existiram entre os grupos, podem não ter sido detectadas pelo método escolhido.

Ao serem comparadas as diferenças da glicemia pós versus pré-exercício físico (tanto para a etapa 1, quanto para a etapa 2), pôde-se observar que, após o exercício até a exaustão, etapa 1, os níveis de glicemia foram, em média, inferiores aos níveis pré-exercício, para todos os grupos, embora não tenham sido encontradas diferenças significantes. Um dos fatores que talvez tenha influenciado não haver diferenças entre os grupos foi, além do número amostral pequeno nesta etapa $(n=3$ por grupo), o elevado erro-padrão da média para esta variável. Apesar de não terem ocorrido diferenças estatisticamente significantes, é possível perceber que houve uma 
menor redução da glicemia, em média, para o grupo $\mathrm{C}$, quando comparado aos demais grupos, o que seria explicado justamente pelo fato de esse grupo não ter sido submetido ao exercício até a exaustão. Sabe-se que, quanto maior o tempo de exercício, maior será a utilização dos estoques de glicogênio muscular. Como as reservas de glicogênio são suficientes para pouco mais de uma hora de esforço de intensidade moderada, a partir daí, os músculos passariam a depender também da captação e, subsequente, oxidação da glicose circulante, podendo, desta forma, manter sua contração (CURI ET AL., 2003).

$\mathrm{Na}$ etapa 2, sessão de exercício com sessenta minutos de duração, ao se avaliarem as diferenças entre a glicemia pós versus pré-exercício, foram encontradas diferenças significantes para o grupo CFNE, quando comparado ao $\mathrm{C}$ e ao $\mathrm{CE}$ e entre o grupo CME quando comparado ao grupo CE. Pôde-se notar a partir destes resultados que nos grupos em que foram administrados cafeína e chá-mate, os níveis de glicemia sanguínea aumentaram após sessenta minutos de exercício. Foi possível observar que, em média, o grupo CE foi o que apresentou a maior queda na glicemia, ao serem comparados os valores pós versus pré-exercício, ou seja, apresentou, em média, uma queda maior da glicemia após sessenta minutos de exercício, enquanto que o grupo CAFE, em média, manteve preservados seus níveis glicêmicos.

Como já descrito anteriormente, dentre os possíveis efeitos da cafeína sobre o metabolismo, estaria a maior mobilização de lipídeos e, possivelmente, a maior utilização de AG durante o exercício (STUART et al., 2005 e GOLDSTEIN et al., 2010), que faria com que o organismo poupasse suas reservas de glicogênio, fazendo desta forma com que a glicemia fosse mantida nos grupos que ingeriram cafeína (ALTIMARI, 2000), o que poderia explicar em parte os resultados obtidos no 
presente trabalho. Complementarmente, nesta etapa também foi possível dosar o conteúdo de glicogênio muscular, não sendo observada nenhuma diferença significante entre os grupos.

Com relação à lipólise, sabe-se que ela é melhor estimada pela determinação do glicerol liberado (JUNIOR et al, 2002). Para que isso fosse possível, tanto na etapa 1 , quanto na etapa 2, a taxa lipolítica foi determinada, por meio da liberação de glicerol em meio estimulado com isoproterenol e sem o estímulo (basal). Com a estimulação com isoproterenol foi possível mimetizar uma situação de aumento da sinalização simpática, como ocorre, por exemplo, durante o exercício físico e então ao analisar a diferença entre a taxa de lipólise estimulada versus a basal, verificando a quantidade de glicerol que estaria sendo liberada nesta situação. Na etapa 1, pôdese observar que a taxa de lipólise foi $92 \%$ superior para o grupo CAFE, quando comparada ao grupo $\mathrm{C}$, havendo uma forte tendência $(\mathrm{p}=0,054)$ de estar aumentada também quando comparada ao grupo CE. Embora a etapa 1 tenha como fator limitante o número amostral baixo, é possível afirmar que apenas a administração do café ocasionou o aumento significante da atividade lipolítica, nas condições estudadas. Na etapa 2, tanto o grupo CFNE, quanto o grupo CAFE, apresentaram a taxa lipolítica aumentada, quando comparados ao grupo C (150\% e $233 \%$ superiores, respectivamente) e ao grupo $\mathrm{CE}$ (51\% e $101 \%$ superior, respectivamente), indicando haver uma maior taxa de lipólise nos grupos em que foram administradas a cafeína isolada, assim como no grupo que recebeu o café. Juntamente a esses resultados, o grupo CFNE apresentou níveis de glicemia mais elevados ao final da sessão de exercício, quando comparado ao grupo CE e níveis mais elevados em média, sem diferença significativa, no conteúdo de glicogênio muscular. Embora não tenha 
havido diferença significativa, quando o grupo CFNE foi comparado aos outros grupos, para o conteúdo de glicogênio muscular, os resultados poderiam indicar para um efeito "poupador" de glicogênio, embora não seja possível fazer essa afirmação, pois além de não haver diferenças estatisticamente significantes, não se pode afirmar que houve uma maior oxidação de AG, mas apenas uma maior hidrólise dos estoques de TAG.

A intervenção com chá-mate, embora tenha ocasionado uma elevação na glicemia pós-exercício, não apresentou nenhum indicativo de que a lipólise estaria aumentada ou que o glicogênio muscular estivesse sendo poupado. Já no caso da intervenção com café, os resultados apontam para uma taxa lipolítica aumentada. Embora sem diferença significante entre os grupos, o grupo CAFE apresentou, em média, níveis mais baixos de glicogênio muscular enquanto sua glicemia pareceu ter sido mantida. Assim como na etapa 1, na etapa 2 o grupo CAFE apresentou a lipólise aumentada quando comparado ao grupo $\mathrm{C}$ e, apenas na segunda etapa, quando comparada ao grupo CE (na etapa 1, apenas forte tendência). Embora o café e o chámate contivessem o mesmo valor aproximado da própria intervenção com a cafeína (7 mg/kg de massa coporal), foi possível notar que, dependendo de sua matriz, o comportamento não é o mesmo ao da cafeína isolada. ACHESON et al. (1980) estudaram os efeitos de uma bebida à base de café (contendo $4 \mathrm{mg}$ de cafeína/kg de massa corporal) em indivíduos obesos e controles. Embora tenha havido um aumento na taxa metabólica de ambos os grupos, houve aumento na oxidação de gorduras apenas para o grupo controle.

ENGELS e HAMES (1992) observaram um aumento significante na mobilização de AGL em indivíduos não treinados e que haviam consumido cafeína 
$(5 \mathrm{mg} / \mathrm{kg})$ e se exercitado por sessenta minutos. COLE et al. (1996) ao estudarem doses de cafeína de $6 \mathrm{mg} / \mathrm{kg}$ em indivíduos sedentários, relataram um aumento na mobilização do glicerol e do AG, embora o protocolo de exercício tenha sido diferente ao proposto no presente trabalho.

RYU et al. (2001) estudaram os efeitos da cafeína no desempenho de ratos e em atletas. Os ratos receberam $6 \mathrm{mg} / \mathrm{kg}$ de cafeína sessenta minutos antes da sessão de exercício. Após $0 \mathrm{~min}-30 \mathrm{~min}-60 \mathrm{~min}$ de exercício foram sacrificados. Os atletas receberam dose equivalente a $5 \mathrm{mg} / \mathrm{kg}$ de cafeína e se exercitaram até a exaustão. Os autores observaram que a taxa de AGL estava aumentada nos ratos e nos atletas e, além disso, nos ratos, o consumo da cafeína havia reduzido a utilização de glicogênio durante o exercício, quando comparados ao grupo controle.

Com relação aos resultados obtidos para o chá-mate, embora não seja possível compará-los a trabalhos anteriores com propostas semelhantes, pela ausência dos mesmos, há outros estudos que abordam outros aspectos, além dos possíveis efeitos antioxidantes no organismo. ANDERSEN \& FOGH (2001) observaram uma diminuição na velocidade do esvaziamento gástrico dos voluntários, atribuindo possivelmente esses efeitos à presença de saponinas, pois aumentariam a saciedade pela diminuição na velocidade do esvaziamento gástrico. ARÇARI et al. (2009), embora tenha observado a redução na massa corpórea de camundongos tratados com erva-mate, não observou redução da ingestão calórica dos animais. MARTINET et al. (1999) que verificaram, apenas para o tratamento com Ilex paraguariensis (1.5g) uma redução no QR quando comparado ao placebo, sugerindo que esses resultados poderiam indicar uma maior proporção de lipídeos oxidados após a ingestão aguda da erva, apontando para um possível benefício nos processos de emagrecimento. 
Como pode ser observado no presente trabalho, um dos principais substâncias presentes no chá-mate são os compostos fenólicos. Embora não tenha sido encontradas diferenças significativas quando o grupo CME foi comparado aos demais, exceto para a variável glicemia (em comparação ao grupo CE), não pode ser descartada a hipótese de que o chá-mate, assim como também o café, por se tratar também de uma matriz complexa, que contêm diversas outras substâncias em sua constituição, não apresente o mesmo comportamento de substâncias que os compõem, como é o caso da cafeína. Para serem observados os efeitos da cafeína, quando ingerida isolada, já existe uma série de fatores interferentes, então supõe-se que, quando combinada à outras substâncias, outros fatores poderiam interferir na sua ação. NEHLIG e DEBRY (1994) sugerem, por exemplo, que se espere três horas após a ingestão da cafeína, pois seu efeito na lipólise poderia ser maior após este período.

Pôde-se observar por meio deste trabalho que, a administração de substâncias químicas isoladas ou o refino de princípios ativos provenientes de alimentos podem não apresentar os mesmos efeitos no organismo quando comparados aos mesmos que estão presentes naturalmente na complexa matriz que são os alimentos ou plantas. Em alguns casos, pode ainda não ser totalmente isento de riscos, ainda mais nos casos nos quais não se tem disponíveis estudos científicos rigorosamente controlados acerca das substâncias. Nem sempre o conhecimento popular pode ser comprovado tão facilmente através das pesquisas e, por isso, muitas vezes, ao se estabelecerem comparações, os resultados podem ser inconclusivos ou mesmo serem antagônicos. Embora não tenha sido o caso do presente trabalho, no qual se tentou fazer uma analogia inversa (a partir da substância química isolada, escolher produtos que 
possuíssem essa mesma substância em sua composição - no caso a cafeína), a simples idéia de extrair princípios ativos de produtos que fazem parte da alimentação habitual, poderia desprezar a interação e sinergismo que muitas vezes ocorrerem entre as substâncias presentes nos mesmos, podendo não serem obtidos os benefícios desejados. 


\section{CONCLUSÃO}

Após exercício em esteira rolante (até a exaustão) com administração prévia de cafeína, café e chá-mate, pôde-se concluir que, independente da intervenção à qual o animal foi submetido, não foi observada diferença significante no desempenho físico entre os grupos, quando comparados ao grupo controle exercício (ingeriu água e fez exercício). Houve redução significativa da massa corporal nos animais submetidos ao exercício físico, quando comparados ao grupo controle, porém sem serem observadas diferenças na variação de glicemia (pós versus pré-exercício) entre os grupos. A ingestão de café aumentou a taxa de lipólise, quando comparado o grupo que ingeriu café ao grupo controle e apresentou forte tendência a estar aumentada quando comparada ao grupo controle exercício.

Após exercício em esteira rolante (duração de sessenta minutos) com administração prévia de cafeína, café e chá-mate, pôde-se concluir que houve redução significativa da massa corporal nos animais submetidos ao exercício físico, quando comparados ao grupo controle e também houve maior na variação (aumento) da glicemia (pós versus pré-exercício) para o grupo que ingeriu cafeína, quando comparado ao grupo controle e ao grupo controle exercício. O grupo que ingeriu chámate também apresentou o mesmo comportamento, quando comparado ao grupo controle exercício. A ingestão de cafeína, assim como a de café, aumentaram a taxa de lipólise nos respectivos grupos, quando comparados ao grupo controle e ao grupo controle exercício. 


\section{REFERENCIAS BIBLIOGRAFICAS}

ABIC - História do café. Desenvolvido pela Associação Brasileira da Indústria do Café (ABIC). Disponível em: <http://www.abic.com.br/publique/ cgi/cgilua.exe/sys/start.htm?sid=38>. Acesso em 11 ago. 2011.

ABIFISA - Associação Brasileira das Empresas do Setor Fitoterápico, Suplemento Alimentar e de Promoção da Saúde . Informações sobre os fitoterápicos brasileiros, 2004. Disponível em: <http://www.abifisa.org.br>. Acesso em: 18 jan 2012.

ACHESON， K.J.; ZAHORSKA-MARKIEWICZ， B.; PITTET， P.; ANANTHARAMAN, K.; JEQUIER, E. Caffeine and coffee: their influence on metabolic rate and substrate utilization in normal weight and obese individuals. Am. J. Clin. Nutr., v. 33, p. 989- 397, 1980.

AHIMA, R.S.; FILER, J.S. Adipose tissue as na endocrine organ. Trends. Endocrinol. Metab., v. 11, p. 327-332, 2000.

ALTIMARI, L. R.; CYRINO, E. S.; ZUCAS, S. M.; BURINI, R. C. Efeitos ergogênicos da cafeína sobre o desempenho físico. Rev. Paul. Educ. Fís., v.14, n.2, p.141-158, 2000.

ALTIMARI, L. R.; CYRINO, E. S.; ZUCAS, S. M.; OKANO, A. H. Cafeína: ergogênico nutricional no esporte. Rev. Bras. Ciên. e Mov., Brasília, v. 9, n. 3, p. 57-64, 2001. 
AltimARI, L. R., MORAES, A. C.; TIRAPEGUI, J. O.; MOREAU, R. L. M. Caffeine and performance in anaerobic exercise. Braz. J. Pharm. Sci., v. 42, p. 1727, 2006.

ALTIMARI, L. R.; FONTES, E. B.; OKANO, A. H.; TRIANA, R. O.; CHACONMIKAHIL, M. P. T.; MORAES, A. C. The caffeine ingestion increases time to neuromuscular fatigue and performance during supramaximal cycling exercise. Braz. J. Biomotricity, v. 2, n. 3, p. 195-203, 2008.

ALVES, R. C.; CASAL, S.; OLIVEIRA, B. Benefícios do café na saúde: mito ou realidade? Quím. Nova, São Paulo, v. 32, n. 8, 2009 . Disponível em <http://www.scielo.br/scielo.php?script=sci_arttext\&pid=S010040422009000800031 \&lng=en \&nrm=iso $>$. Acesso em 27 nov. 2011.

ANDERSEN, T.; FOGH, J. Weight loss and delayed gastric emptying following a South American herbal preparation in overweight patients. J. Hum. Nutr. Diet., v. 14, p. 243-50, 2001.

ARÇARI, D. P.; BARTCHEWSKY, W.; SANTOS, T. W.; OLIVEIRA, K.; FUNCK, A.; PEDRAZZOLI, J.; SOUZA, M. F. F.; SAAD, M. J., BASTOS, D. H. M., GAMBERO, A.; CARVALHO P. O.; RIBEIRO, M. L. Antiobesity Effects of yerba maté Extract (Ilex paraguariensis) in High-fat Diet-induced Obese Mice. Obesity, v. 17, n. 12, p. 2127-2133, 2009.

BALMAIN, J. H.; BIGGERS, J. D.; CLARINGBOLD, P. J. Micromethod for the estimation of glycogen in the genital organs of the mouse. Aust. J. Biol Sci, v. 9, p. 139-146, 1955. 
BASTOS, D. H. M; FORNARI, A. C.; QUEIROZ, Y. S.; SOARES, R. A. M.; TORRES, E. A. F. S. The Chlorogenic Acid and Caffeine Content of Yerba Maté. Acta Farm. Bonaerense, v. 24, n. 1, p. 95-105, 2005.

BASTOS, D. H. M.; ISHIMOTO, E. Y.; MARQUES, M. O. M.; FERRI, A. F.; TORRES, E. A. F. S. Essential oil and antioxidant activity of green mate and mate tea (llex Paraguariensis) infusions. J. Food Anal., v. 19, n. 6-7, p. 538-543, 2006.

BASTOS, D. H. M.; OLIVEIRA, D. M.; MATSUMOTO, R. L.; CARVALHO, P. O.; RIBEIRO, M. L. Yerba maté: pharmacological properties, research and biotechnology (invited review). Med. Aromat. Plant. Sci. Biotechnol., v. 1, p. 37-46, 2007a.

BASTOS, D. H. M.; SALDANHA, L. A.; CATHARINO, R. R.; SAWAYA, H. F.; CUNHA, I. B. S.; CARVALHO, P. O.; EBERLIN, M. N. Phenolic antioxidants identified by ESI-MS from Yerba Maté (Ilex paraguariensis) and Green Tea (Camelia sinensis) extracts. Molecules, v. 12, p. 423-432, 2007b.

BASTOS, D. H. M.; TORRES, E. A. F. S. Bebidas a base de Erva-Mate (Ilex paraguariensis) e Saúde Pública. Nutrire, v. 26, p. 77-89, 2003.

BELlET, S., KERSHBAUM, A.; FINCK, E. M. Response of free fatty acids to coffee and caffeine. Metabolism, v. 17, p. 702-707, 1968.

BORILLE, A. M. W.; REISSMANN, C. B.; FREITAS, R. J. S. Relação entre compostos fitoquímicos e o nitrogênio em morfotipos de erva-mate (Ilex paraguariensis St. Hil.). Boletim CEPPA, v. 23, n. 1, p. 183-198, 2005.

BRENELLI, E. C. S. A extração de cafeína em bebidas estimulantes: uma nova abordagem para um experimento clássico em química orgânica. Quím Nova, v. 26, n. 1, p. 136-138, 2003. 
BRASIL. Agência Nacional de Vigilância Sanitária. Regulamento técnico para fixação de identificação e qualidade de café torrado em grão e café torrado e moído. Portaria no 377, de 26 de abril de 1999. Ministério da Saúde, 1999. BROUNS, F.; VAN DER VUSSE, G. J. Utilizations of lipids during exercise in human subjects: metabolic and dietary constraints. Braz. J. Nutr., v. 79, p. 117-128, 1998.

BRUNETTO, D.; RIBEIRO, J. L.; FAYH, A. P. T. Efeitos do consumo agudo de cafeína sobre parâmetros metabólicos e de desempenho em indivíduos do sexo masculino. Rev Bras Med Esporte, vol. 16, n. 3, p. 171-175, 2010.

CAMPANHA, F. G.; DIAS, R. C. E.; BENASSI, M. T.; Coffee Science, 2010, no prelo.

CARRATU, E.; SANZINI, E. "Sostanze biologicamente attive presenti negli alimenti di origine vegetable”. Ann. Ist. Super Sanità, 41 (1), p.7-16, 2005.

CARDOZO JUNIOR, E. L.; FERRARESE-FILHO, O.; CARDOZO FILHO, L.; FERRARESE, M. L. L.; DONADUZZI, C. M.; STURION, J. A. Methylxanthines and phenolic compounds in mate (Ilex paraguariensis St. Hil.) progenies grown in Brazil. J. Food Compos. Anal., v. 20, p. 553-558, 2007.

COSTA, A. F. Farmacognosia. 4.ed. Lisboa: Fundação Calouste Gulbenkian, v. 2, 1994.

COSTILL, D. L; DALSKY, G. P.; FINK, W. J. Effects of caffeine ingestion on metabolism and exercise performance. Med. Sci. Sports., v. 10, n. 3, p. 155-158, 1978. 
COX, G. R.; DESBROW, B.; MONTGOMERY, P. G.; ANDERSON, M. E., BRUCE, C. R.; MACRIDES, T. A.; MARTIN, D. T.; MOQUIN, A.; ROBERTS, A., HAWLEY, J. A.; BURKE, L. M. Effect of different protocols of caffeine intake on metabolism and endurance performance. J Appl Physiol., v. 93 n. 3, p. 990-9, 2002. CURI, R.; LAGRANHA, C. J.; RODRIGUES JR., J. G.; PITHON-CURI, T. C.; LANCHA JR, A. H.; PELlEGRINOTTI, E. L.; PROCOPIO, J. Ciclo de Krebs como fator limitante na utilização de ácidos graxos durante o exercício aeróbico. Arquivos Brasileiros de Junior et al metabolismo dos acidos graxos no exercício físico em Curi R, Pompéia C, Miyasaka CK, Procópio J. Entendendo as gorduras: os ácidos graxos. São Paulo: Manole; cap 16. 2002.

DALL AGNOL, T. M.; CIERO, P. D. Bebidas energéticas e seus componentes. Nutrição em Pauta, n. 57, p. 42-45, 2002.

DEL COSO, J.; ESTEVEZ, E.; MORA-RODRIGUES, R. Caffeine effects on shortterm performance during prolonged exercise in the heat. Med. Sci. Sport. Exer., v. 40, n. 4, p. 744-751, 2008.

DIGIROLAMO, M.; MENDLINGER, S.; FERTIG, J. W. A simple method to determine fat cell size and number in four mammalian species. Am. J. Physiol., v. 221, p. 850-858, 1971.

DIEPVENS, K.; WESTERTERP, K. R.; WESTERTERP-PLANTENGA, M. S. Obesity and thermogenesis related to the consumption of caffeine, ephedrine, capsaicin, and green tea. Am. J. Physiol. Regul. Integr. Comp. Physiol., v. 292, n. 1, p. 77-85, jan. 2007. 
DOHERTY, M.; SMITH, P. M. Effects of caffeine ingestion on exercise testing: a meta-analysis. Int. J. Sport. Nutr. Exerc. Metab., v. 14, n. 6, p. 626-46, 2004.

EGGER, G. Physical exercises against obesity. In: $9^{\text {th }}$ International Congress on Obesity, São Paulo, 2002.

ESSING, D.; COSTILL, D. L.; VAN HANDEL, P. J. Effects of caffeine ingestion on utilization of muscle glycogen and lipid during leg ergometer cycling. Med. Sci. Sports Exerc., v. 1, p. 86-90, 1980.

FERREIRA, G. M. H.; GUERRA, G. C. B.; GUERRA, R. O. Efeitos da cafeína na percepção do esforço, temperatura, peso corporal e freqüência cardíaca de ciclistas sob condições de stress térmico. Rev. Bras. Ciênc. Mov., v. 14, n. 2, p. 33-40, 2006. FRANÇA, A. S.; MENDONÇA, J. C. F.; OLIVEIRA, S. D. Composition of green and roasted coffees of different cup qualities. Food Sci. Technol., v. 38, n. 7, p. 709$715,2005$.

FINUCANE, M. M; STEVENS, G. A.; COWAN, M. J.; DANAEI, G.; LIN, J. K.; PACIOREK, C. J.; SINGH, G. M.; GUTIERREZ, H. R.; LU, Y.; BAHALIM, A. N.; FARZADFAR, F.; RILEY, L. M.; EZZATI, M. On behalf of the Global Burden of Metabolic Risk Factor of Chronic Diseases Collaborating Group (Body Mass Index). National, regional, and global trends in body mass index since 1980: Systematic analysis of health examination surveys and epidemiological studies with 960 country-years and 9.1 million participants. Lancet; v. 377 n.9765, p. 557-567, 2011

FRANCISCHI, R. P. P.; PEREIRA, L. O.; FREITAS, C. S.; KLOPFER, M.; SANTOS, R. C.; LANCHA JUNIOR, A. H. Obesidade: atualização sobre sua etiologia, morbidade e tratamento. Rev. Nutr., v. 13, n. 1, p. 17-28, 2000. 
FRANS, I. W ; LOHMANN, F. W; KOCH, G.; QUABBE, H. J. Aspects of hormonal regulation of lipolisys during exercise effects of chronic beta-receptor blockade. Int J Sports Med, v. 4, p. 14-20, 1983.

GANIO, M. S.; CASA, D. J.; ARMSTRONG, L. E., MARESH, C. M. Evidencebased approach to lingering hydration questions. Clin. Sports Med., v. 26, n. 1, p. 116, 2007.

GENOVESE, M. I.; SANTOS, R. J.; HASSIMOTO, N. M. A.; LAJOLO, F. M. Determinação do conteúdo de fenólicos totais em frutas. Braz. J. Phar. Sci., n.39, p.167-169, 2003.

GLAISTER, M.; HOWATSON, G.; ABRAHAM, C. S.; LOCKEY, R. A.; GOODWIN, J. E.; FOLEY, P.; MCINNES, G. Caffeine Supplementation and multiple Sprint Running Performance. Med. Sci. Sports Exer., v. 40, n. 10, p. 18351840, 2008.

GLASS, R. M. Caffeine dependence: what are the implications. JAMA, v. 272, n. 13, p. 1065-1066, out. 1994.

GODOY-MATOS, A. F.; MOREIRA, R. O. Síndrome metabólica: implicações clínicas e tratamento. Diabetes mellitus, n. 16, p. 171-182, 2006.

GOLDSTEIN, E. R.; ZIEGENFUSS, T.; KALMAN, D.; KREIDER, R.; CAMPBELL, B.; WILBORN, C.; TAYLOR, L.; WILLOUGHBY, D.; STOUT, J.; GRAVES, B. S.; WILDMAN, R.; IVY, J. L.; SPANO, M.; SMITH, A. E.; ANTONIO, J. International society of sports nutrition position stand: caffeine and performance. J. Int. Soc. Sports Nutr. 2010, v. 7, n. 5, 2010. 
GNOATTO, S. C. B.; SCHENKEL, E. P.; BASSANI, V. L. HPLC method to assay total saponin in Ilex paraguariensisaqueous extract. J. Braz. Chem. Soc., v. 16, n. 4, 723-726, 2005.

GRAHAM, T.E. Caffeine, coffee and ephedrine: impact on exercise performance and metabolism. Can. J. Appl. Physiol., v. 26, suppl s, p. 103-119, 2001.

GRAHAM, T. E.; HELGE, J. W.; MACLEAN, D. A.; KIENS, B.; RICHTER, E. A. Caffeine ingestion does not alter carbohydrate or fat metabolism in human skeletal muscle during exercise. J. Physiol., Lond., v. 529, p. 837-847, 2000.

GRAHAM, T. E.; HIBBERT, E.; SATHASIVAM, P. Metabolic and exercise endurance effects of coffee and caffeine ingestion. J. Appl. Physiol., v. 85, n. 3, p. 883-889, 1998.

GRAHAM, T. E.; SPRIET, L. L. Performanceand metabolic responses to a high caffeine dose duringprolonged exercise. J. Appl. Physiol., v. 71, p. 2292-2298, 1991.

GREENBERG, J. A.; BOOZER, C. N.; GELIEBTER, A. Coffee, diabetes, and weight control. Am. J. Clin. Nutr., v. 84, p. 682-693, 2006.

GUYTON, A. C.; HAll, J. E. Tratado De Fisiologia Médica. 9. Ed. Rj . Guanabara Koogan, 1997.

HAMER B. Coffee and health: explaining conflicting results in hypertension. J. Hum. Hypertens., v. 20, p. 909-12, 2006.

HASKELL, W. L.; LEE, I. M.; PATE, R. R.; POWELL, K. E.; BLAIR, S. N.; FRANKLIN, B. A. ET AL. Physical activity and public health: Updated recommendation for adults from the American College of Sports Medicine and the American Heart Association. Circulation, v. 28, p. 1081-1093, 2007. 
HECK, C. I.; MEJHA, E. G. Yerba mate Tea (Ilex paraguariensis): a comprehensive onchemistry, health implications, and technological considerations. J. Food Sci., v. 72, n. 9 , p. 138-151, 2007.

HIGDON, J. V., FREI, B. Coffee and health: a review of recent human research. Crit. Rev. Food Sci. Nutr., v. 46, n. 2, p. 101-23, 2006.

HULSTON, C. J.; JEUKENDRUP, A. E. Substrate metabolism and exercise performance with caffeine and carbohydrate intake. Med. Sci. Sport Exer., v. 40, n. 12, p. 2096-2104, 2008.

ILLY, A.; VIANI, R. Espresso Coffee: the Science of Quality; 2nd ed., Elsevier Academic Press: London, 2005.

ICH - INTERNATIONAL CONFERENCE ON HARMONISATION. Validation of Analytical Procedures: Methodology, Q2B, 1996.

International Coffee Organization. Sobre o café. [Acesso em: 20 out 2011]. Disponível em: www.ico.org

IVY, J. L.; COSTILL, D. L.; FINK, W. J., LOWER, R. W. Influence of caffeine and carbohydrate feedings on endurance performance. Med. Sci. Sports Exerc., v. 11, n. 1, p. 6-11, 1979.

JAISWAL, R.; SOVDAT, T.; VIVAN, F.; KUHNERT, N. Profiling and Characterization by $\mathrm{LC}^{-M S^{\mathrm{n}}}$ of the Chlorogenic Acids and Hydroxycinnamoylshikimate Esters in Maté (Ilex paraguariensis). J. Agric. Food Chem., v. 58, p. 5471-5484, 2010. 
JEUKENDRUP, A. E.; SARIS, W. H. M.; WAGENMAKERS, A. J. M. Fat metabolism during exercise: A review-Part I: Fatty Acid Mobilization and Muscle Metabolism. Int. J. Sports Med., v. 9, p. 231-44, 1998.

KY, C. L.; LOUARN, J.; DUSSERT, S.; GUYOT, B.; HAMON, S.; NOIROT, M.; Caffeine, trigonelline, chlorogenic acids and sucrose diversity in wild Coffea arabica L. and $C$. canephora P. accessions. Food Chem., v. 75, n. 2, p. 223-230, 2001 .

KOVACS, E. W. R.; JOS, H.C.H. S.; BROUNS, F. Effect of caffeinated drinks on substrate metabolism, caffeine excretion, and performance. J. Appl. Physiol., v. 85, n. 2, p. 709-715, 1998.

LAKKA, T. A.; LAAKSONEN, D. E.; LAKKA, H-M.; MÄNNIKKÖ, N.; NISKANENN, L. K.; RAURAMAA, R. Sedentary life style, poor cardiorrespiratory fitness, and the metabolic syndrome. Med. Sci. Sports Exerc., n. 35, p. 1279-86, 2003.

LIN, C.; MUELleR, L. A.; CARTHY, J. M.; CROUZILlAT, D.; PÉTIARD, V.; TANKSLEY, S. D. Coffee and tomato share common gene repertoires as revealed by deep sequencing of seed and cherry transcripts. Theor. and Appl. Genet., v. 112, p. 114-130, 2005.

LOGUERCIO, A. P.; BATTISTIN, A. VARGAS, A. C.; HENZEL, A.; WITT, N. M. Atividade antibacteriana de extrato hidro-alcoólico de folhas de jambolão (Syzygium cumini (L.) Skells). Cienc. Rural, v. 35, n. 2, abr. 2005. Disponível em <http://www.scielo.br/pdf/cr/ v35n2/a19v35n2.pdf > Acesso em 12 outubro 2011.

MACINTOSH, B . R .; WRIGHT, B .M. Caffeine ingestion and performance of a 1,500-metre swim. Can. J. Appl. Physiol., v. 20, n. 2, p. 168-177, 1995. 
MAHAN, L. K.; ESCOTT-STUMP S. Krause's food \& nutrition therapy. 12th ed. St. Louis, Mo.: Saunders/Elsevier; 2008. p. xxiv, 1352 p.

MANDEL, H. G. Update on caffeine consuption, disposition and action. Food Chem. Toxicol., v. 40, p. 1231-1234, 2002.

MAUGHAN, R. J. Nutrição Esportiva. Artmed Editora, 2004

MCARDLE, W. D.; KATCH, F. I.; KATCH, V. L. Nutrição para o desporto e o exercício. 2.ed. Rio de Janeiro: Guanabara Koogan, 2001.

MENDES, M.; GOMES, M. R.; ROSSI, L.; TIRAPEGUI, J. Suplementos ergogênicos e atividade física. In: Nutrição: Fundamentos e aspectos atuais. Julio Tirapegui ed, São Paulo, Ed Atheneu, p.161-178, 2000.

MERCK INDEX. An encyclopedia of chemicals and biologicals. New Jersey: Merck Researchs Laboratories, Division of Merck \& CO, Inc., 1996. p. 248, 359, 1583 e 1584.

MILLARD-STAFFORD, M. L.; CURETON, K. J.; WINGO, J. E.; TRILK, J.; WARREN, G. L.; BUYCKX, M. Hydration during exercise in warm, humid conditions: effect of a caffeinated sports drink. Int. J. Sport Nutr. Exerc. Metab., v. 17, n. 2, p. 163-77, 2007.

MONTEIRO, M. C.; TRUGO, L. C. Determinação de compostos bioativos em amostras comerciais de café torrado. Química Nova, v. 28, p. 637-41, 2005.

MOREIRA, R. F. A.; TRUGO, L. C.; DE MARIA, C. A. B. Componentes voláteis do café torrado. Parte II. Compostos alifáticos, alicíclicos e aromáticos. Quim. Nova, v. 23, p. 195-203, 2000. 
MOREIRA, R. F. A.; TRUGO, L. C.; DE MARIA, C. A. B.; MATOS, A. G. B.; SANTOS, S.M.; LEITE, J.M.C. Discrimination of Brazilian arabica green coffee samples by chlorogenic acid composition. Arch. Latin. Nutr., v. 51, n. 1, p. 94-99, 2001 .

NABHOLZ, T. V. Nutrição esportiva: Aspectos relacionados a suplementação

nutricional. São Paulo: Sarvier, 2007.

NEHLIG, A. "Are we dependent upon coffee and caffeine? A review on human and animal data." Neurosci. Biobehav. Rev., v. 23, n. 4, p. 563-576, 1999.

NEHLIG, A.; DEBRY, G. Caffeine and sports activity: a review. Int. J. Sports Med., v. 15, p. 215-223, 1994.

NELSON, D. L.; COX, M. M. Lehninger princípios de bioquímica. 3. ed. São Paulo: Sarvier, 2002.

NEWSHOLME, E.A. An introduction to the roles of the glucose-fatty acid cycle in sustained exercise. In: Biochemistry of exercise IX, Eds. MAUGHAN R.J \& SHIRREFFS S.M. Human Kinects Publishers: Champaign, 1996.

OLIVEIRA, D, M.; BASTOS, D. H. M. Biodisponibilidade de ácidos fenólicos. Quím. Nova, São Paulo, v. 34, n. 6, 2011.

PANG, J.; CHOI, Y.; PARK, T. 2008. Ilex paraguariensis extract ameliorates obesity induced by high-fat diet: Potential role of AMPK in the visceral adipose tissue. Arch Biochem Biophys., v. 476, p. 178-185, 2008.

PASTOR, V. J.; RUIZ, M.; ACOSTA, A.M. \& AVILA, C. Metabolic and hormonal changes during aerobic exercise indistance runners. J. Physiol. Biochem, v. 55, p. 7$16,1999$. 
POF 2008-2009: desnutrição cai e peso das crianças brasileiras ultrapassa $\begin{array}{llll}\text { padrão internacional. } & \text { Disponível }\end{array}$ <http://www.ibge.gov.br/home/presidencia/noticias/noticia_visualiza.php?id_noticia =1699\&id_pagina=1>. Acesso em 08/09/2011].

POKOLENKO, J. J.; SCHMALKO, M. E. Contenido de cafeína y extracto acuoso y su velocidad de extracción en la yerba mate en diferentes épocas de cosecha. Revista

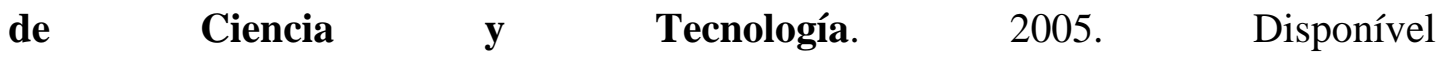
em:<http://www.alimentosargentinos.gov.ar/03/infusion/Trab_Interes/Cafeina_EA.p df>.Acesso em março 2011.

PRICE R. Genetics and common obesities: background, current status, strategies, and future prospects. In: Wadden T, Stunkard AJ, eds. Handbook for Obesity Treatment. New York, NY: Guilford Press; p.73-94, 2002.

PRZYGODDA, F.; MARTINS, Z. N.; CASTALDELli, A. P. A.; MINELlA, T. V.; VIEIRA, L. P.; CANTELLI, K. F.; JORDANA, P.; MARISTELA, J. Effect of erva-mate (ilex paraguariensis a. st.-hil., aquifoliaceae) on serum cholesterol, triacylglycerides and glucose in Wistar rats fed a diet supplemented with fat and sugar. Rev. bras. farmacogn., Curitiba, v. 20, n. 6, Dec. 2010 . Disponível em: <http://www.scielo.br/scielo.php?script=sci_arttext\&pid=S0102695X201000060002 2\&lng=en\&nrm=iso>. Acesso em 11 Dez 2011.

RANHEIM, T.; HALVORSEN, B. Coffee consumption and human health beneficial or detrimental?-mechanisms for effects of coffee consumption on different risk factors for cardiovascular disease and type 2 diabetes mellitus. Mol. Nutr. Food Res., v. 49, n. 3, p. 274-284, 2005. 
RATES, S. M. K. Metilxantinas em Farmacognosia. Da planta ao medicamento, Simões, C. M. O; Schenkel, E. P.; Gosmann, G., Mello, J. C. P.; Mentz, L. A. Petrovick PR. (eds), 3a. edição, Editora da UFSC Florianópolis, SC e Editora da Universidade/UFRGS, Porto Alegre, RS, 2001.

REUTERS. Disponível em: <http://br.reuters.com/article/domesticNews/idBRSPE79 60EI20111007?pageNumber=1\&virtualBrandChannel=0> Acesso em 20 out 2011.

RIBANI, M.; BOTTOLI, C. B. G.; COLLINS, C.; JARDIM, I. C. F. S.; MELO, L. F. C. Validação de métodos cromatográficos e eletroforéticos. Química Nova[online]. 2004, vol.27, n.5, pp. 771-780. ISSN 0100-4042. Disponível em http://dx.doi.org/10.1590/S0100-40422004000500017> Acesso em 05 jun 2011.

ROBERGS, R. A. Princípios Fundamentais de Fisiologia do Exercício: para aptidão, desempenho e saúde. São Paulo: Phorte, 2002.

RODBELL, M. Metabolism of isolated fat cells. Effects of hormones on glucose metabolism and lipids. J. Biol. Chem., v. 239, p. 357-380, 1964.

ROWBOTTOM, D. G.; GREEN, K. J. Acute exercise effects on the imune system. Med. Sci. Sports Exerc., Madison, v. 32, p. S396-S405, 2000.

RUBAYIZA, A. B.; MEURENS, M. Chemical discrimination of Arabica and Robusta coffees by Fourier transform raman spectrometry. J. Agric. Food Chem., v. 53: 4654-4659, 2005.

RYU, S.; CHOI, S. K.; JOUNG, S. S.; SUH, H.; CHA, Y. S.;LEE, S.; LIM, K. J. Caffeine as a lipolytic food component increases endurance performance in rats and athletes. Nutr Sci Vitaminol (Tokyo), v. 47, n. 2, p. 139-46, 2001. 
SAES, M. S. M; NISHIJIMA, M. Drawback para o café solúvel brasileiro: Uma análise de mercado. Revista da Economia Mackenzie, v. 5, n. 5, 2007.

SALGADO, J. M. Faça do alimento o seu medicamento. $4^{a}$ ed. São Paulo, Madras, 2000.

SALINAS, R. D. Alimentos e nutrição: Introdução à bromatologia. $3^{\text {a } e d . ~ S a ̃ o ~}$ Paulo, Artmed, 2002.

SAWYNOK, J.; YAKSH, T. L. Caffeine as an analgesic adjuvant: a review of pharmacology and mechanisms of action. Pharmacol. Rev., v. 45, p.43-85, 1993.

SILVA, G. J. J.; BRUM, P. C.; NEGRÃO, C. E.; KRIEGER, E. M. Acute and chronic effects of exercise in spontaneously hypertensive rats. Hypertension, v. 30, n. 3, p. 714-719, 1997.

SILVA, R. D.; BUENO, A. L.; GALLON， C. W.; GOMES， L. F.; KAISER, S.; PAVEI, C.; ORTEGA, G. G.; KUCHARSKI, L. C.; JAHN, M. P. The effect of aqueous extract of gross and commercial yerba mate (Ilex paraguariensis) on intraabdominal and epididymal fat and glucose levels in male Wistar rats. Fitoterapia, v. 82, n. 6, p. 818-26, 2011.

SILVEIRA, L. R.; ALVES, A. A.; DENADAI, B. S. Efeito da lipólise induzida pela cafeína na performance e no metabolismo de glicose durante o exercício intermitente. Rev. Bras. Ciênc. Mov., v. 12, n. 3, p. 21-26, 2004.

SINCLAIR, C.; GEIGER, J. Caffeine use in sports: A pharmacological review. J. Sports Med. Phys. Fitness, v. 40, n. 1, p. 71-79, 2000.

SJODIN, B.; JACOBS, I.. On set of blood lactate accumulation and marathon running performance. Int. J. Sports Med., v. 2, p. 23-26, 1981. 
SMITH, A. W. Em Coffee: Chemistry; CLARKE, R. J.; MACRAE, R., eds.; Elsevier Applied Science Publishers: London, 1987, vol. 1.

SORENSEN, T. I. The genetics of obesity. Metab., v.44, n. 9(3), p. 4-6, 1995.

SPEER, K.; KOLLING-SPEER, I. The lipid fraction of the coffee bean. Braz. J. Plant. Physiol., v. 18, n. 1, p. 201-16, 2006.

SPRIET, L. L., HOWLETT, A. Caffeine. In: Maughan, R. J., edithor. Nutrition in sport. Oxford: Blackwell Science Ltd, p. 379-392, 2000

STUART, G. R.; HOPKINS, W. G.; COOK, C.; CAIRNS, S. P. Multiple Effects of Caffeine on Simulated High-Intensity Team-Sport Performance. Med. Sci. Sports Exerc. v. 37, n. 11., p. 1998-2005, 2005.

TARNOPOLSKY, M. A. Caffeine and endurance performance. Sports Med., v. 18, n. 2, p. 109-125, 1994.

TAYLOR, S. R,.; DEMMIG-ADAMS, B. To sip or not to sip. The potential health risks and benefits of coffee drinking. Nutr. Food Sci., v. 37, p. 406-18, 2007 THOMPSON, P. D.; CROUSE, S. F.; GOODPASTER, B.; KELLEY, D.; MOYNA, N.; PESCATELLO, L. The acute versus chronic response to exercise. Med. Scie. Sports Exe., Madison, v. 33, p. S438-S445, 2001.

TRUDEAU, F.; Bernier, S.; De Glisezinski, E. Lack of antilipolytic effect of lactate in subcutaneous abdominal adipose tissue during exercise. J. Appl. Physiol., v. 86, p. 1800-1804, 1999.

YUNES, R. A.; CECHINEL FILHO, V. Breve análise histórica de plantas medicinais: sua importância na atual concepção de fármaco segundo os paradigmas ocidental e oriental. In: YUNES, R.A.; CALIXTO, J.B. (eds.).Plantas 
medicinais sob a óptica da química medicinal moderna. p.17-46, Chapecó: Argos, 2001.

YVE, J. L.; COSTILL, D. L.; FINK, W. J.; MAGLISCHO, E. Contribution of medium and long chain triglyceride intake to energy metabolism during prolonged exercise. Int. J. Sports Med., v. 1, p. 15-20, 1980.

WADA. World Anti Doping Agency. The 2010 prohibited list international standard. Disponível em: http://www.wada-ama.org/en/World-Anti-DopingProgram/. Acesso em 08 nov 2010.

WAHRENBERG, H.; ENGFELDT, P.; BOLINDER, J.; ARNER, P. Acute adaptation in adrenergic control of lipolysis during physical exercise in humans.Am J Physiol, v. 253, p. 383-90, 1987.

WALLMAN, K. E.; GOH, J. W.; GUELFI, K. J. Effects of caffeine on exercise performance in sedentary females. J. Sports Sci Med, v. 9, p. 183-189. 2010.

WAXMAN, A. WHO's global strategy on diet, physical activity and health: Response to a worldwide epidemic of non-communicable diseases. Scand. J. Nutr., v. 48, n. 2 , p. $58-60,2004$.

WEGENER, G.; KRAUSE, U.; NEWSHOLME, E.A. Metabolic regulation physiological and medical aspects. Experientia, v. 52, p. 391-395, 1996.

WEMPLE, R. D.; LAMB, D. R., MCKEEVER, K. H. Caffeine vs caffeine-free sports drinks: effects on urine production at rest and during exercise. Int J Sports Med, v. 18, n. 1, p. 40-46, 1997.

WILlET, W. C. Coma, beba e seja saudável. $1^{\text {a }}$ ed. Bras., São Paulo, Campus, 2002. 
WILMORE, J. L.; COSTILL, D. L. Fisiologia do esporte e do exercício. 2 ed. São Paulo: Manole, 2001.

WHO (World Health Organization). Diet, nutrition and the prevention of chronic diseases. (Technical Report Series, 797). Geneva, p. 69-73, 1990.

WHO (World Health Organization). Obesity: Preventing and Managing the Global Epidemic. Report of a WHO Consultation on Obesity. Geneva: WHO, 1998. WHO (World Health Organization). Obesity and Overweight. Disponível em: <http://www.who.int/mediacentre/factsheets/fs311/en/ index.html> Acesso em 10 ago 2011. 
8 CURRICULO LATTES (AUTORA DA TESE) 
9 CURRICULO LATTES (ORIENTADORA DA TESE) 